University of Louisville

ThinkIR: The University of Louisville's Institutional Repository

Electronic Theses and Dissertations

$12-1949$

\title{
The separation of zirconium and hafnium by distillation : II. an engineering appraisal of aluminum structural materials.
}

\author{
Everard G. Baker
}

Follow this and additional works at: https://ir.library.louisville.edu/etd

Part of the Chemical Engineering Commons

\section{Recommended Citation}

Baker, Everard G., "The separation of zirconium and hafnium by distillation : II. an engineering appraisal of aluminum structural materials." (1949). Electronic Theses and Dissertations. Paper 2262.

https://doi.org/10.18297/etd/2262

This Master's Thesis is brought to you for free and open access by ThinkIR: The University of Louisville's Institutional Repository. It has been accepted for inclusion in Electronic Theses and Dissertations by an authorized administrator of ThinkIR: The University of Louisville's Institutional Repository. This title appears here courtesy of the author, who has retained all other copyrights. For more information, please contact thinkir@louisville.edu. 


\title{
r.s.
}

UNIVERSITY OF LOUISVILLE

\section{PART I}

THE SEPARATION OF ZIRCONTUM AND HAFNIUM BY DISTILLATION PART II

AN ENOINEERING APPRAISAL OF ALOMINUM STRUCTURAL MATERIALS

\author{
A Thesis \\ Submitted to the Paculty \\ of the Graduate School \\ of the University of Louisville \\ In Partial Fulfiliment \\ of the Requirements \\ For the Degree of \\ MASTER OF CHEMICAL ENGINEERING \\ Department of Chemleal Inglneering \\ Brerard G. Baker, Jr.
}


This PDF document is a scanned copy of a paper manuscript housed in the University of Louisville (UofL) Libraries. The quality of this reproduction is greatly dependent upon the condition of the original paper copy. Indistinct print and poor quality illustrations are a direct reflection of the quality of materials that are available for scanning. The UofL Libraries greatly appreciates any better copies that can be made available for replacement scans. 
PART I

THE SEPARATION OF ZIRCONIUM AND HAFNIUM BY DISTILIATION

PART II

AN ENGINEERING APPRAISAL OF ALUMINUM STRU CTURAL MATERIALS

Everard G. Baker, Jr.

Approved by the Examining Commltteo

\begin{tabular}{ll} 
Direotor_ Gordon C. Williams \\
D1reotor $\frac{\text { W. B. Wendt }}{\text { W. R. Barnes }}$ \\
\hline
\end{tabular}

Deoember, 1949 
PART I

THE SEPARATION OF ZIRCONIUM AND HAFNIUM BY DISTILLATION 
TABLE OF CONTENTS

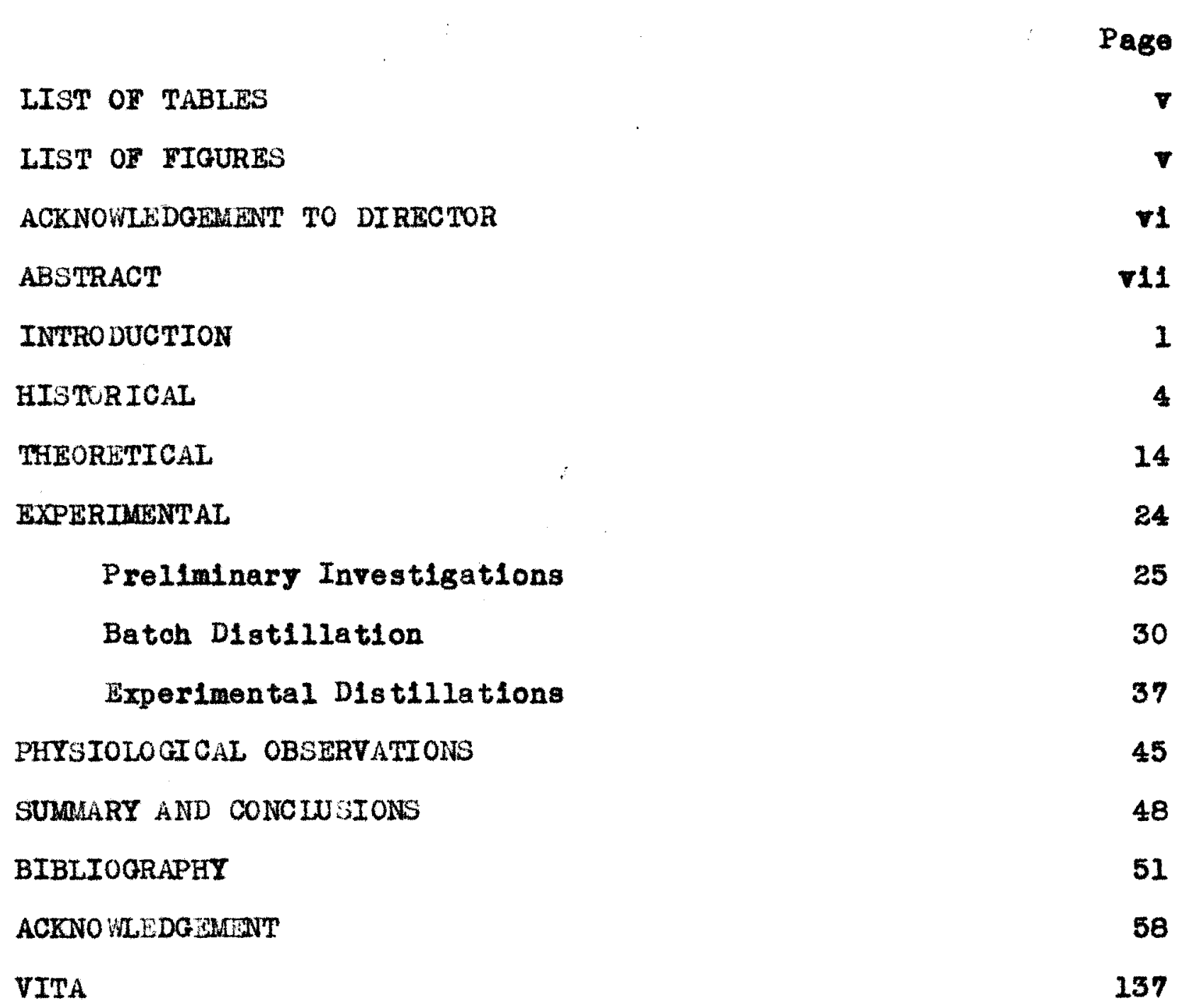




\section{LIST OF TABLTS}

TABLF

Pago

I Caloulations for Bqulibriun Curvo 17

II Batch Distillation Data 20

II Melting and Bolling Polnt Data 28

IV Batoh Distiliation Data 32

V Time Log for Paoked Colum Operation 42

LIST $\alpha$ FIOURES

Pgure

Page

1 Caloulated Bqullibrium Curvo 18

2 Experimental Equilibrium Curve 22

3 Batoh Columin

31

4 Strippor Column

38

5 Production Column

44 
The Author W1 shes to Acknowledge

The Kind Assistance and Helpful Quidance of

Dr. G. C. W1111ans

Who Directed This Portion of the Research 
ABSTRACT 


\begin{abstract}
A compliation of references dealing with the separation of bafnium and zirconium is presented, together with an evaluation of their possibilities. It is concluded that a distillation procedure holds the greatest promise. The theory of the separation of hafnium and zirconfum by distillation of sultable compounds is given and experimental investigations are presented for confirmation.
\end{abstract}


INTRODUCTION 
The element zirconlum has been known since the latter balf of the elghteenth century. (77) Early chemists isoleted the oxide and sllicate from various ands found throughout the world and for several decades it was thought that compounds prepared from these ores were pure. However, the presence of a second material was suspected s early a 1900 (107) when variations in physical properties were found if the compounds were prepared from raw materials from different sources. It was not until 1923 thet conclusive proof, was discovered and the impurity was proven to be new element (78). Th1s new element, which bas recelved the name of hafnium, was found later in all zicon sands in varying amounts in metal concentration ratio from less than two-tenths per cent by welght to as much as sixteen per cent (64). The average concentration however, was approximately three per cent by weight hafnium in the naturally occuring ores. Durlng the years following the discovery and 1solation of hafnium, much work has been done on its separation, and the 11 tereture contains numerous references to the problem, but to this time no completely satisfactory method for the separation of ziroconlum and hafnium bas been found.

The object of this thesis was to develop those phases of the research preceeding the development of a pllot plant for the separation of zirconium and hafnium by a dstiliation pro$\cos 8$.

The problem was to produce zirconium containing less than hafnium-zirconium ratio of $0.01 / 100$ by welght, from commercial grade zirconlum tetrachloride. This commercial grade 
zirconium tetrachloride contalned an approximate ratio of $3 / 100$ bafnium tetrachloride, by welght, with lesser amounts of iron, ti tanium, aluminum, and chromiun. These lesser impurities were not considered in thl s problem a their removal has been successfully accomplished in subsequent operations by other methods.

This research has been conducted at the University of Loulsvi21e Institute of Industrial Research as a part of contract research for the Atomic Energy Comnission. 
HISTORICAL 
Zirconfum was first isolated, in compound form, and Identified by M. H. Klaproth (77) in the late elghteenth century. He precipl tated the compound from a dilute solution with potassium carbonate. This precipitate did not display the properties by whicb other then known elements were ldentified, and Klaproth proposed it as a new earth.

In 1824, J. J. Berzelius (77) isolated the metal from the salt that Klaproth had described, and confirmed the discovery of ziroonium.

The remeinder of the nineteenth century passed witb the study of the chemistry of zirconium and the establisbment of 1 ts physical and chomical properties. Complete agreement on the physical properties was not possible because of the ex1stence of the element hafnium, which was not then known and which occurred in all zirconium ores, but much of the chemistry of zirconiun was determined, because as was proved later, the chemistry of hafnlum and zirconlum was practically identical. In 1911, G. Urbain (78) 1 solated a merlal from the rare earths, which be called celtium, and he clalmed 1 t to be - lement number seventy-two, whlch from the perlodic chart, now would be bafnlum. In later years, this identification was proved to be incorrect as bls actual work was not duplicated. In 1921, J. W. Marden and M. N. Rlch mado reasonably complete (75) survoy of the literature of zirconium. This survey mos no mention of the element now known as hafnium, Indicating thet little then was known about it. Published information and much of the original work by the United States, 
Bureau of Mnes during World War I were included in this survey. In 1922, A. Dauvieliler (78) obtained the first X-ray spectrum of an element admitted to be number seventy-two.

For several gears before Deuviellier's work there was a protracted alscussion between the followers of Urbain, who would clags element number seventy-two as a rare earth, and those who would class it a a homologue of zirconium. This discussion continued for some years even aiter the actual discovery.

In January, 1923, D. Coster and G. von Hevesy (6) (78) separated a material from zirconlum and titanium compounds baving an X-ray spectrum matching that obtalned by Dauvieller. Element number seventy-two, if considered a a homologue of zirconium could be suspected to be present with naturally occurring zirconlum. Furtbermore, it was established that the X-ray spectrum agreed with the Bohr Theory for this new element.

Thus, the discovery of hafnium, element number seventy two, was firmly established. It was named bafnium, for an anclent name of the city of Copenhagen, Denmark where coster and Hevesy worked.

The chemical similarity of zirconium and hafnium directed much of the research connected with them toward methoda for their separation. Both elements belong to the $\mathrm{RO}_{2}$ famlly of the periodic group IV. Moreover, hafniun's properties are oloser to those of 1 ta lower bomologue, z1rconlum than they are to those of 1 ts higher bomologue thorlum (57). Until a satisfactory method for separation could be perfected, the determi- 
nation of the properties of the pure elemental zirconiun could not be advanced further, nor could the properties of the now olement hafnium be established.

Following the alscovery of hafnlum many attempts were made to purify and 1 solate elther or both bafnium and a1rconium, and the 11 terature contains numerous articles roporting variety of approsches to the problem.

In the year 1923 a re-evaluation was made of the bafnium content of many zirconium ores, by $G$. von Hevesy and $V$. T. Jantzen. (62). It was found that all zirconium ores were similarly contaminated, and the hafnium concentration ranged from less than two tenths per cent in some to more than sixteen per cent in a fow. In tho same year these men ostablished a mothod of separation by fractional crystallization of the double alkali fluorides (63).

In the year 1923 also Gloellampenfabrieken $N . V . P$. obtained a series of British patents for the separation of bafnium from zirconium. Some of the methods of separation covered by these patents are:

(1) Fractional crystallization of sulfates (40).

(2) Fractional crystalization of oxychlorides (41).

(3) Fractional crystallization of fluoridea (43).

(4) Fractional crystalilation of higher oxy salts (42).

(5) Fractional crystallization of oxalates (44).

(6) Distillation of complex chlorides (45), formed from zirconiun and hafnium tetrachlorides and phosphorous pentachloride. It was reported that the hafnium fraction distilled 
from $230^{\circ} \mathrm{C}$. to $360^{\circ} \mathrm{C}$, and that the zirconium fraction distilled from $360^{\circ} \mathrm{C}$. to $410^{\circ} \mathrm{C}$.

In 1924, Gloel lampenfabricken, N. V. P. (55) obtained

a United states petent covering 1 tem number $81 x$ (6) listed above, but which further states that other complexes formed from elements of the fifth and sixth groups of the periodic chart with zirconium and hafnium te trachlorides may lso be distillod.

A. E. Van Arkel and J. H. Do Boer in 1924, (101) published procedure for separation of the two elements by what they termed fractional sublimation of the complexes formed with phosphorus pentachloride. They further presented the formula of the complexes as $2 \mathrm{HCl}_{4} \cdot \mathrm{PCl}_{5}$ where represents -1 ther metal. The freezing point for the zirconium complex, $2 \mathrm{ZrCl}_{4} \cdot \mathrm{PCl}_{5}$ was determined a $164.5^{\circ} \mathrm{C}$. and the bolling point as $416^{\circ} \mathrm{C}$. At this same time A. E. Van Arkel and J. H. De Boer prepared the phosphorus oxychloride complexes (77), and determined their bolling points approximately $360^{\circ} \mathrm{C}$. A fractional distillation was carried out, and the research of this thesis is alrect outgrowth of their work. Van Arkel and De Boer filed for United States patent covering frectional crystallization of double iluorides in 1924.

Also in 1924, D. Coster and $G$. Von Hevesy filed for United states patents covering the following methods of separation:

(1) Fractional precipltation a the hydroxides (9).

(2) Fractional precipltation as the sulfates (10). 
(3) Fractional crystallization as double fluorides (11).

(4) Fractional crystallization as oxy-halogen compounds, (12). A method of separation using the double ammonium eltrates, was published in 1925, bJ D. H. Drophy and W. P. Davey (31). A good separation was reported as the hafnlum compound are more soluble than the corresponding zircontun compounds. M. Merquis (76), In 1925 , reported separation of hafnium and zirconium from the ore, malacon, by a fractlonal preolpltation of the sulfates similar to that previously patented.

British patents covering further separations were granted to Gloe1lampenfabrieken, N. V. P., in 1925:

(1) Separation of hafnlum from zirconfum by seleotive precip1tation in phosphate solutions (47).

(2) Depositing of metallic hafnium or zirconfum on electric lamp fllaments from the gas phase by control of temperature (48). G. von Hevesy and $\mathrm{E}$. Madsen (65) claim separation by use of alkall double fluorides in a series of fractionations to produce 99.9 per cent hafaium. The greatest purlty obtalned to this date. A large number of steps were probably neoessary to obtain this figure.

The following methods of separation:

(1) Fractional preolpitation of oxides (94).

(2) Fractional distiliation of hulldes (91).

(3) Fractional orystallization of phosphates in the presence of an organio solvent (95). were covered in Canadian patents issued in 1925, to A. E. Van Arkel and J.H. De Boer. They also obtained several United 
States patents and among them:

(1) Phosphates dissolved in Oxallc acid and fractionally precipitated with hydrochloric acid. (101).

In 1926, J. Kendall and W. West (70) ttempted a separation by the lonic migration method using complex oxalates. The degree of separation wes not great.

D. Coster and G. von Hevesy (18) obtained a Canadien patent in 1927 covering precipitation of higher besic compounds from ether solutions.

J. H. De Boer published two articles in 1927. One, on the separation of hafnium from zirconium as the phosphate from sulfuric acld solution (21), the other method was the fractional decomposition of the phosphates in hydrofluoric acld solution by use of borlc acid, or other boron compounds. (23).

During the late 1920's many of the above mentioned authors obtained patents in several different countries, covering their particular methods of separation.

In 1930 , G. von Hevesy and H. O. Wagner (66) reported that hafnium halides were less soluble than zirconlum halldes in concentrated bydrofluoric acid.

J. H. DeBoer and J. Broos (29) reported in 1930 that by using sulfuric acid fractionation, the second fraction - liminated all zirconium. It would seem, however, thet this is in error inasmuch as others bave used essentially the same method wi thout such phenomenal results.

In 1931, government document, by P. M. Tyler (90) presented a discussion on methods of separation of hafnium and 
alrconium, up to that date with information on the preparation of pure hafnium salta.

W. Prandt (83) in 1932, fractionated hafniun from zirconium in a solution of amonium sulfate and oxal1c acid. He obtalned bafnlum dioxide of $95.5 \%$ purity in three fractionations. In 1935, Prandtl obtained anlted States patent using the fractional precipitation of the ferrocyanides to obtain a separation.

G. von Hevesy and W. Dullenkopt, in 1934, fractionally sublimed the tetrafluorides, and only obtalned partial separation, but they did examino the orystals and recorded the orystal constants.

In 1942, W. C. Schlumb and F. K. P1t tman (89) reexamined the work of W. Prandtl on the ferrocyanide method. They succeeded in changing the composition of a mixture from - 22/88 ratio of hafnium to zirconiun to an $80 / 20$ ratio on the same basis in four fractionations.

$$
\text { E. M. Larsen, (73) in } 2943 \text { attempted a new technique }
$$
on the old method of fractionally crystallizing phosphates from a sulfuric cid solution, as shown by $J$. H. De Boer in 1927 (22). He sprayed dilute solutions of zirconyl-hafnyl sulfates and phosphoric acid simultaneousiy into ten per cent solution of sulfuric ac1d. The precipitete was treeted with sodium hydroxide peroxide solution and digested at seventy degrees centigrade. In seven fractionations the hafnlum content was ralsed from thirteen to ninety three per cont.

H. H. W1111ard and H. Fround (106) attempted a frac- 
tional precipl tetion of a triethyl phosphate complex. In this method, instead of adding the preclpituting agent, 1t was allowed to form slowly in the mixture by hydrolysis. The separation was not extensive. It was reported in 1946.

A government document (72) published in 1946, by W. J. Kroll and W. W. Schlechten again reviewed the li terature on zirconium and refers only vaguely and briefly to hafnium separation. Th1s work of W. J. Kroll and A. W. Schlechten was presumably an extension of the publication of J. W. Marden and M. N. Rlch. (75). Other articles referring to the history, preparation and purification of zirconlum, some of them as late as 1947, completely Ignore the existence of the element bafnium (58) (71) (68).

The reasons for the apparent lack of attention to hafnium are quite simple. Since zirconium and hafnium are so much alike in thelr chemlcal properties, they do not interfere with one another in many commerclal uses today. Fur thermore, there are no significant uses of bafnium lone and therefore, it is not speciflcally desired in volume.

Apparently now flelds of research are opening up whlch make a commercial separation of these two elements both desirable and necessary, therefore in 1949, D. M. Gruen and J. J. Katz at Argonne liational Laboratories, Chlcago, Illinols (56) extended the work of A. E. Van Arkel and J. H. De Boer on the distillation of the phosphorus pentachloride and phosphorous oxychloride complexes. In their results they present value of relative volatility, $\alpha$, for the separation of the phospho- 
rus oxyohloride complexes, and established $1.5 \mathrm{ZrCl}_{4} \cdot \mathrm{POCl}_{3}$ and $1.5 \mathrm{HFCl}_{4} \cdot \mathrm{POCl}_{3}$ as more acourate formula for the complexes. In this same work a serles of distillations 1s reported with the use of varlous types of fraotlonating columns.

With the exception of distillation, the previously discussed methods for the separation of the se two elements are essentlally batch operations. Batch teohniques are fundamentally expensire and time consuming and to obtaln any high degree of enriohment a very large number of operations are necessary. For this reason such methods as orystallization and preolpitation are usually left to cases where other procedures fall.

The prooess of distillation has been developed through many centur les to a point were it may be a contlnuous operation and because of this, it often excells in comparison with other separations.

A. E. Van Arkel and J. H. De Boer (77) state, in their writings, that other complexes, similar to the phosphorus complexes, may be made of elements of the fifth and sixth groups of the perlodic table, however, so far as can be determined no othex complexes have been made.

The position of phosphorus in the periodic chart would indloate that, if other complexes could be made, these complexes would be of higher moleoular welghts and would lead to the conolusion that they would probably have higher bolling polnts, making them less eas1ly alstillable. 
THEORETICAL 
The separation of hafnium from zirconium as shown in the bistorical section has been the subject of considereble research, and the methods for separation are almost as numerous as the men who have investigated the subject. However, there are no commercial methods for separating the two elements in existence today. Many variations bave been proposed for fractional separation by means of orystallization, precipitation, decomposition, etc. but there have been only a limited number of references to distillation procedure. Thls is somewhat surprising as distillation process is normaliy much more efficient than any of the other proposed operations. The reason for this lack of adaptation of distilintion to the problem is probably because a far as is known, there are only two relatively stable compounds of zirconium and hafnium which will undergo distillation, they are $1.5 \mathrm{NCl}_{4} \cdot \mathrm{PCl}_{5}$ and $1.5 \mathrm{MCl}_{4} \cdot \mathrm{POCl}_{3}$ where $\mathrm{Nefers}$ to the metel. It is reported however that commercial zirconium tetrachloride melts at $437^{\circ} \mathrm{C}$. and 25 a tmospheres (82). If this $1 \mathrm{~s}$ true, it is concelvable that a distillation of the tetrachlorides of these elements could be carried out. However, since it would bave to be under pressure, the method would be less desirable. The theory of distillation is quite well ostablished, and presumably the system could be treated a a simple binary solution composed of $1.5 \mathrm{ZrCl}_{4} \cdot \mathrm{POCl}_{3}$ and $1.5 \mathrm{HFCl}_{4} \cdot \mathrm{POCl}_{3}$, other materials present in suob smell amounts that they could be disregarded.

The difference in bolling points of the two phosphorus oxychloride complexes is apparently very small, an the pure 
hafnium complex bas not boen produced. The bolling point difference 1s, however, in the range of five to ten degrees centigrade. Because the concentration range is gmall, the temperature arop across a column is practically zero. Even with complete separation, the change in temperature has been shown to bo small, (56) and accordingly the operati on approaches adiabatic conditions.

As previousiy cited the relative volatility for this system bas been determined by D. M. Gruen and J.J. Katz (56) a 1.14, m d with this value an equilibrium curve has been calculated (Table I) and plotted in Figure 1. The oquation for this procedure was the standard form, (105).

$$
y=\frac{\alpha x}{1+(\alpha-1) x}
$$

The comercial zirconium tetrachloride contains approximately a hafnium-zirconium ratio by weight of $3 / 100$. It is desired to remove hafnium from the mixture down to a welght ratio of $0.1 / 100$ or less. Th1s was a seomingly small stripping range, yet with the small relative voletility large number of plates were considered necessary.

In this distillation the bafnlum complex, being the lower boller of the two complexes, w11l alstill faster and the tops product 111 be rich in hafnium. In batch operations silicon tetrachloride with its low boling polnt of $57^{\circ} \mathrm{c}$. , if present in the system, w111 dist111 off early since apparently it does not form a complex. IItenlum complex should distill off early in the operation. The ferrous chloride, aluminum, 
TABLE I

CALCULATIONS FOR EQUILIBRIUM CURVS

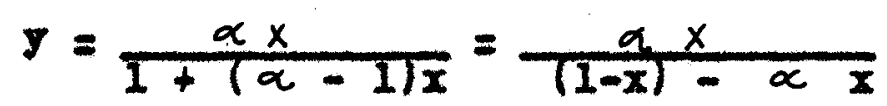

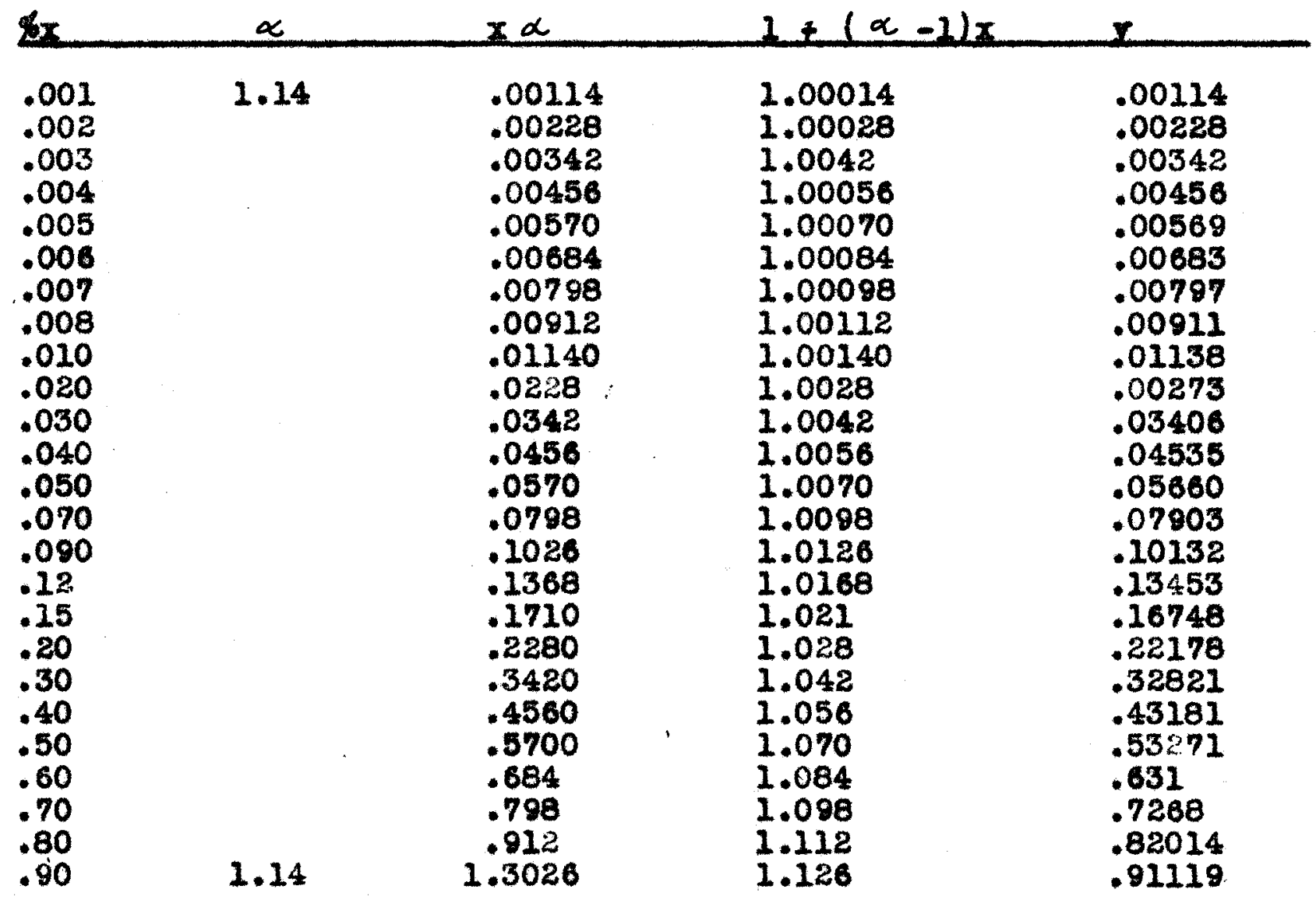

and ohrominum oomplexes remain as impuritles in the bottoms produet $(20)$. In the case of a continuous operation the tops produot w11l be contaminated with the low bolling impurities, the bottoms produot, with the high bolilng impurities.

Batch distillations have been carried out suocessfuliy by D. M. Gruen and J. J. Katz, and the Foote Mineral Company, Philadelphla, Pennsylvania. The data from these sources are shown in Table II and Plotted in Figure 2 . It has been noticed 


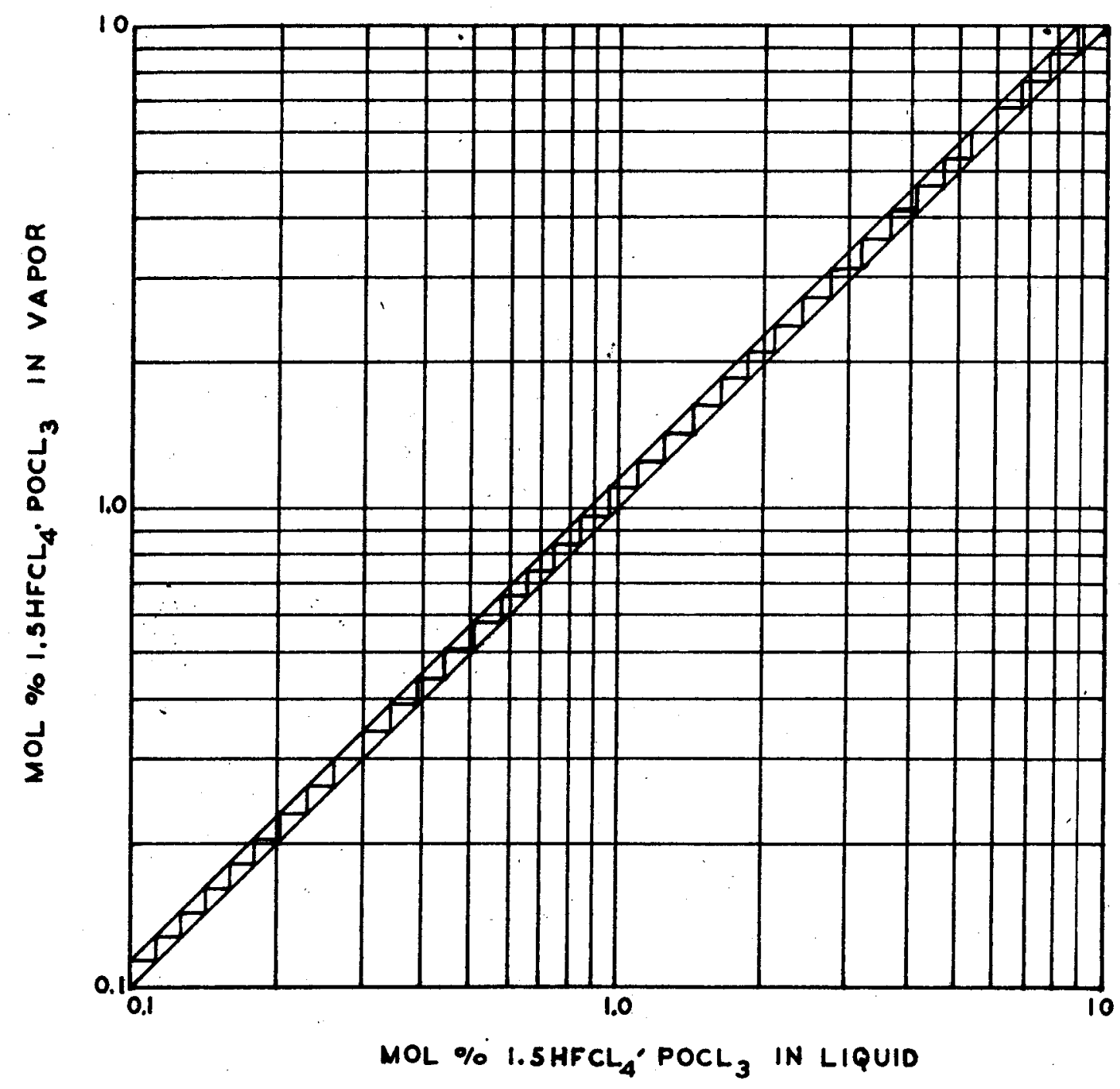

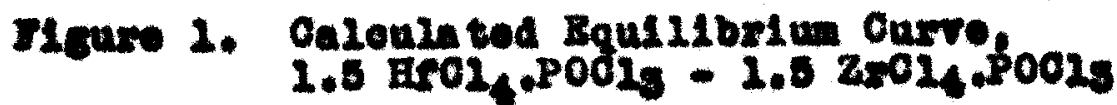


that the data as obtained by D. M. Gruen and J. J. Katz, and the data from few runs from the Foote Mineral Company agree exceptionally well. These data a taken from the original reports were in the form of $\mathrm{He} / \mathrm{Zr}$ ratios $x 100$ by weight and were converted to mol per cent berore plotting on Figure 2 . Since batch distiliation results bad been in substantial agreement between the Argonne and Foote Laboratories it was decided to direct the attention of this investigation to the continuous procedure, particularly as a continuous distillation procedure has three distinct advantages over the batch operation. (85)

(1) Uniform and high grede product

(2) Heat economy

(3) Labor economy

A uniform and bigh grade product is the result of the constant conditions which exist any particular point in the system, once equilibrium has been establishod. There is a continuous and uniform change in the material passing through the system, but a constant set of conditions for ang particular point in the aystem from one time interval to the next. Conversely in a batch operetion, the conditions are constantly changing not only for any point within the system, but also for the end conditions. The composition of the material leaving the system is constantly changing, and because of this, a non-uniform product results. The beat economy of a continuous operation comes from the absence of the numerous Intermediate fractions which use up large quantities of heat 
TABLE II - BATCH DISTILLATION DATA

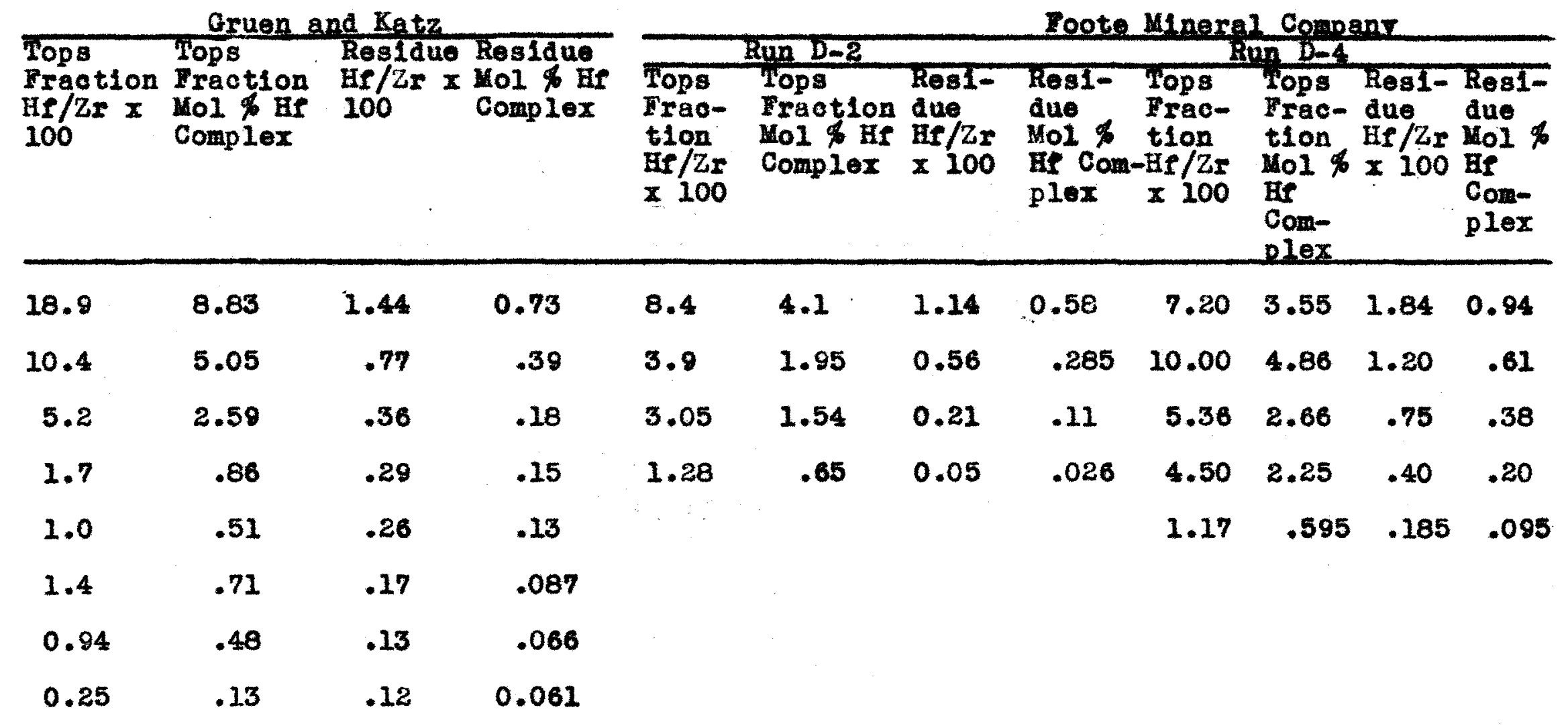




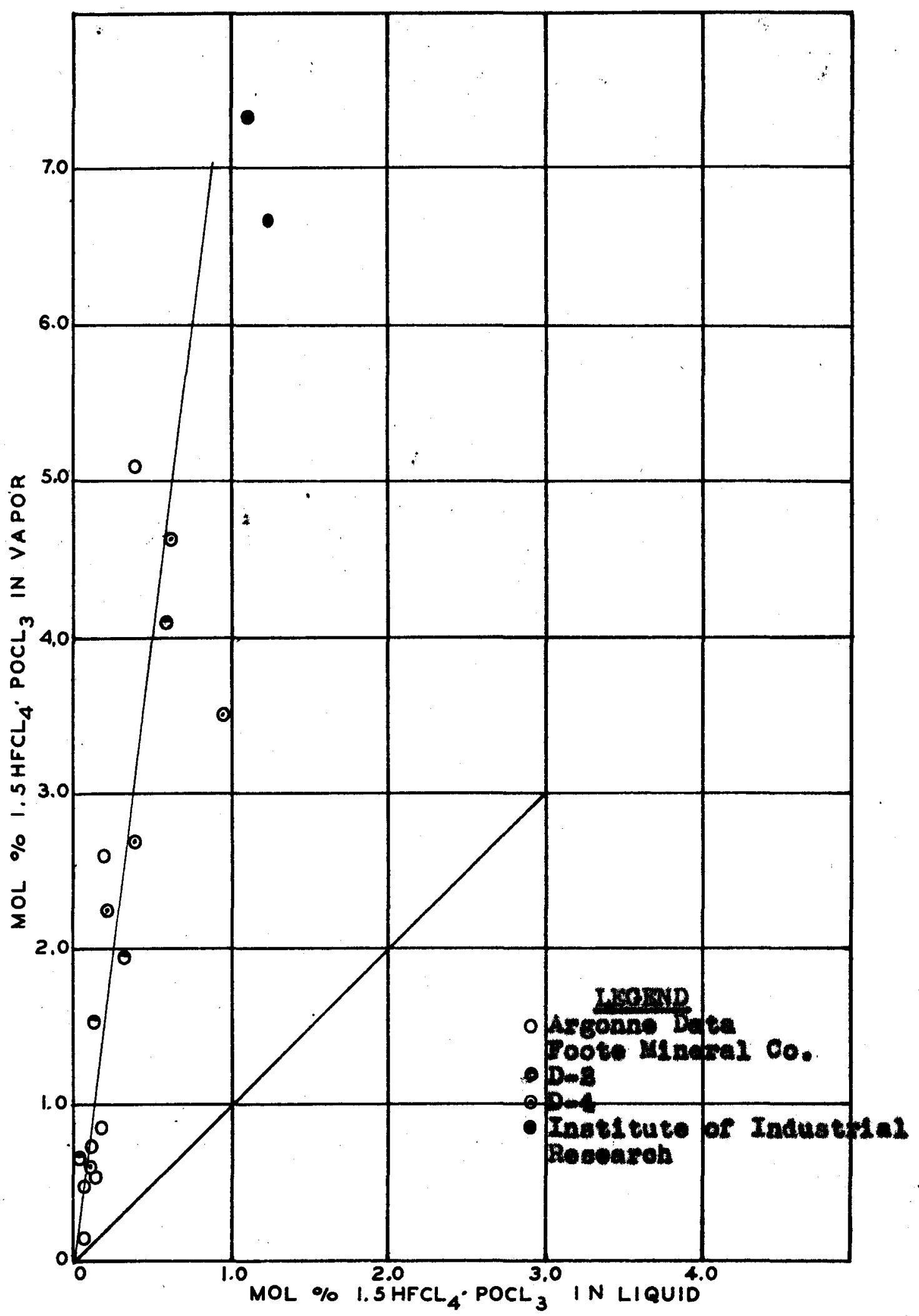

MLgure 2. DLagan sor Bateh DLatLLation. 
in the batch processes. The labor economy for the continuous operation is due to the few intermediate products which must be bandled whilo the batch process needs a relatively large number of unskilled laborers for this work.

There are two factors often against a continuous operation, and in favor of a batch operation. They are:

(1) Exoessive initial cost of apparatus

(2) Complicated construction and operation

The excessive first cost of the continuous plant in this case can be shown to be factor negligible with reference to the operating cost, and no compliceted construction appears to be necessary.

For the particular system under investigation the continuous operation bolds aditional advantages. Some of these are:

(1) Freedom from contact of materials with molsture, which causes decomposition resction resulting in non-distillable compound.

(2) Less contact of personnel with vapors, which are both toxic and bighly $1 \mathrm{rritating}$.

(3) Less decomposition of the complex because of a short heat contact time. It was noted later that there were indications of some type of decomposition due to heat.

(4) Excess phosphorus oxychloride may be recovered in the continuous process.

The method for reporting the hefnium concentrations in zirconium compounds is not uniform. Accordingly, several 
methods for converting Hf/2r $\times 100$ by welght to various other forms are presented.

The molecular weights: HP $=178.6, O=16, C I=35.46$, $P=30.98, \mathrm{Zr}=91.22$.

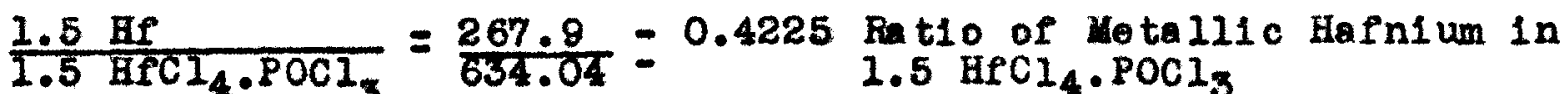
$\frac{1.5 \mathrm{Zr}}{1.5 \mathrm{LrCI}_{4} \cdot \mathrm{POCl}_{3}}=\frac{136.83}{502.95}=0.27205 \frac{\text { Ratio of Metall1c Zirconium in }}{1.5 \mathrm{ZrCI}_{4} \cdot \mathrm{POCI}_{3}}$ Conversion to $\frac{\text { Hf }}{\mathrm{Zr}} \times 100\left(\frac{0.27205}{0.4225}\right) \times \frac{1}{100}=$ Welght Ratio $=$ $\frac{a}{1+a} \times 100=$ Weight Per cent $1.5 \mathrm{HPCl}_{4} \cdot \mathrm{POCl}_{3}$ in mixture $=b$ Conversion to welght per cent metallic hafnium in mixture: b $\times 0.4225=$ Welght per cent metallic bafnium in complex mixture. Conversion to mole per cent $1.5 \mathrm{HeCl}_{4} \cdot \mathrm{POCl}_{3}$ in mixture: $\frac{\text { He }}{\mathrm{ZT}_{\mathrm{r}}} \times 100\left(\frac{91.22}{178.6}\right) \frac{1}{100}=$ Mole Ratio of Complexes $=\mathrm{c}$ $\frac{0}{1+c} \times 100=$ Mole per cent $1.5 \mathrm{HFCl}_{4} \cdot \mathrm{POCl}_{3}$ in mixture. 
EXPERIMETTAL 
Preliminary Investigation

Before ang distillation work was begun, it was desirable to establish the nature of the materials which were to be used and to check certain of the constants which were avallable In the 11 terature.

It was observed that the zirconlum tetrachloride was - Ilght tan color and that it apparently reacted with molsture. This reaction took place spontaneously, upon contact with air, and gave off hydrogen chloride, with an apparent formation of zirconium oxychloride. The pure zirconiun tetracbloride ia aupposediy a white salt, and the color in the commercial grade may be attributed to impurities in the nature of iron, aluminum, titaniun, tc.

The $1.5 \mathrm{ZrCl}_{4} \cdot \mathrm{POCl}_{3}$ complex wes prepared very readily. A quantity of zirconlum tetrachloride was transferred to a flask and an equal molel welght of phosphorus oxychloride was added slowly to avold foaming. The reaction was axothermic to a certain degree. After the mixture had spontaneously reacted, apparently to completion, there was light tan, porous, spongy solid and a quantity of phosphorus oxychloride left in the bottom of the flask. By gently applying heat, the spongy mass apperentIf reacted further w th the phosphorus oxychloride and seemed to melt to a dark green liquid.

In preparing the phosphorus pentachloride complex it wes necessary to alter the method somewhat, since both compounds are solids. Equal molar quantities of the zirconium 
tetrachloride and the phosphorus pentachloride were used in this case 2so, but these powdery sollds were mixed thoroughly and heated. This reaction was not exothermic or sponteneous and it was necessary to apply heat throughout the reaction period. This reaction simflarly produced a dark green liquid.

The removal of the excess phosphorus oxychloride in the preparation of $1.5 \mathrm{ZrCl}_{4} \cdot \mathrm{POCl}_{3}$ was accomplished by dist111ation. The excess phosphorus pentachloride used in the preparation of $1.5 \mathrm{ZrCl}_{4} \cdot \mathrm{PCl}_{5}$ was sublimed off. In each case when a dark green liquid appeared to be refluxing in the flask, it was assumed that the excess phosphorus compound had been removed.

Ho attempt was made to verify the composition of ei ther of the complexes. A. E. Van Arkel and J. H. De Boor established the composition as 2 moles of zirconium tetrachlorIde to one mole of elther the phosphorus oxychloride or the phosphorus pentachloride. The later work by D. M. Gruen and J. J. Katz has cast considerable doubt on these flgures however, and their experiments placed the ratio of zirconium tetrachloride to el ther of the two phosphorus compounds between one and one and half to one. The oxact stolchlometry of the compounds, therefore, bas not been definitely establishod, but the formulas appear to be as follows:

$$
\begin{aligned}
& 1.5 \mathrm{ZrCl}_{4} \cdot \mathrm{POCl}_{3} \text { and } 1.5 \mathrm{HCCl}_{4} \cdot \mathrm{POCl}_{3} \\
& 1.5 \mathrm{ZrCl}_{4} \cdot \mathrm{PCl}_{5} \text { and } 1.5 \mathrm{HfCl}_{4} \cdot \mathrm{PCl}_{5}
\end{aligned}
$$

and w1ll be accopted as such for this work. 
The melting and bolling points of both the phosphorus pentechloride and the phosphorus oxychloride complexes were compared with the Ilterature values.

The boling points were obtained in an 011 beth while the melting points were obtained not only in a similar bath, but also with the use of a Fischer-Johns melting point apparatus. The data are shown in Table III and verify the I1 terature values exceptionally well. It is recognized that these values for the zirconium compounds are inaccurate to the extent that the zirconium tetrachloride is impure, as it contains approximately a Hf/Zr ratio of $3 / 100$ by welght.

Since the exact stolchlometry of the complexes has not been established a question of the stability of these materials was ralsed. It was necessary that the complexes only be stable enough to undergo a distillation and a check was considered to be satisfactory for this purpose.

A fresh batch of the $1.5 \mathrm{MCl} 4 . \mathrm{POCl}_{3}$ complex was prepared and amall amount placed in a test tube. The melting point of this speoimen was obtained, and the test tube and Its contents welghed. The sample then was heated to a slow reflux for thirty-six bours and after this time the melting point and weight again obtained. There was no noticeable change in el ther of these values. It was observed also that the bolling point did not change during the period of reflux and there was no change in the appearance of the complex.

The same stability test was conducted on the 1.5 $\mathrm{MCl}_{4} \cdot \mathrm{PCl}_{5}$ complex with the same results. On the basis of these 


\section{TABLE III}

AEITING AND BOILING POINT DATA

\begin{tabular}{|c|c|c|c|c|}
\hline & $\begin{array}{l}\text { Ll tera ture } \\
\text { Value } \\
\text { Melting } \\
\text { Point } \\
\text { oc. }\end{array}$ & $\begin{array}{l}\text { Experimental } \\
\text { Yalue } \\
\text { Melting } \\
\text { Point } \\
\text { o C. }\end{array}$ & $\begin{array}{l}\text { Li tera ture } \\
\text { Value } \\
\text { Bolling } \\
\text { Polnt } \\
\text { oc. }\end{array}$ & $\begin{array}{l}\text { Experimental } \\
\text { Value } \\
\text { Bolling } \\
\text { Point } \\
\text { o C. }\end{array}$ \\
\hline $1.5 \mathrm{ZrCl}_{4} \cdot \mathrm{POCl}_{3}$ & $-\infty-\infty$ & $80^{\circ}-130^{\circ}$ & 360 & 363 \\
\hline $1.5 \mathrm{ZrCl}_{4} \cdot \mathrm{PCl}_{5}$ & 164.5 & 166 & 410 & 416 \\
\hline
\end{tabular}


results, it was concluded that both of the complexes were stable enough to undergo dist11lation.

since 1 t wa contemplated thet this investigation was to be the Forerunner of a pllot plant design, a series of aimple corrosion tests were made.

A quantity of freshly prepared $1.5 \mathrm{MCl}_{4} \cdot \mathrm{POCl}_{3}$ was prepared and placed in a test tube. Stripg of copper, 302 type stainless steel, 304 type stainless steel, and black iron were placed in the test tube. The corrosion specimens were arranged so thet they would bo in contact with both the liquid and refluxing vapor, but not each other. After perlod of 24 bours of reflux, the specimens were removed for examination. The copper and black iron bad boen severely ttacked and could not be recommended as materials of construction in contact with this complex. The two specimens of stainless ateel showed no corrosion and although checked with alcrometer, no reduction in diameter was indicated. These two stainless ateel specimens wero returned to the refluxing complex for second twenty four hour per1od. Again there was no ovidence of corrosion.

This same type of test was performed using the 1.5 $\mathrm{MCl}_{4} \cdot \mathrm{PCl}_{5}$ complex with the same general results. Howover, the corrosion of the copper and black Iron was more severe than with the phosphorus oxychloride complex. The stainless steels were tested for the extra twenty-four hours, and as before showed no corrosion. Accordingly, it was judged that a stainiess steel would be satiafactory for construction purposes on corrosion atandpoint. Further tests should; however, be conducted in 
order to estabilsh which of the stainless steels would best serve the purpose or if the protection might be elther temporary or colncidental.

Batch Distillation:

The work of D. M. Gruen and J. J. Katz at the Argonne National Laboratories, Chicago, Illinols, established that the zirconlum-hafnium separation could be performed by batch wise distillation in an Oldershaw column of the phosphorus oxychlorIde complexes as had been reported by A. B. Van Arkel and J. H. De Boer.

Since several abnormallties appeared in investigations from both groups, and since rather accurate information was desirable, it was chosen to supplement the data with an independently determined set of Plgures.

A one inch dianeter packed column, seven feet high was ereoted and topped with a spocially designed dividing head as shown in Figure III. A packed column was chosen to furnish comparative data as well as to obtain the information for the previous checking. Th1s column was heated with electrio heatIng mantles oovered with glass fabric and the heating mantles for the two llter Plask whloh served as a still were covered with a quartz oloth. The dividing head was heated with infrared lamps to prevent the complex from freezing. The se heating lamps were used to control the rate of tops product removal, whloh in turn influenoed the reflux ratio, in the column. Variacs were used to control the power input to the heating 


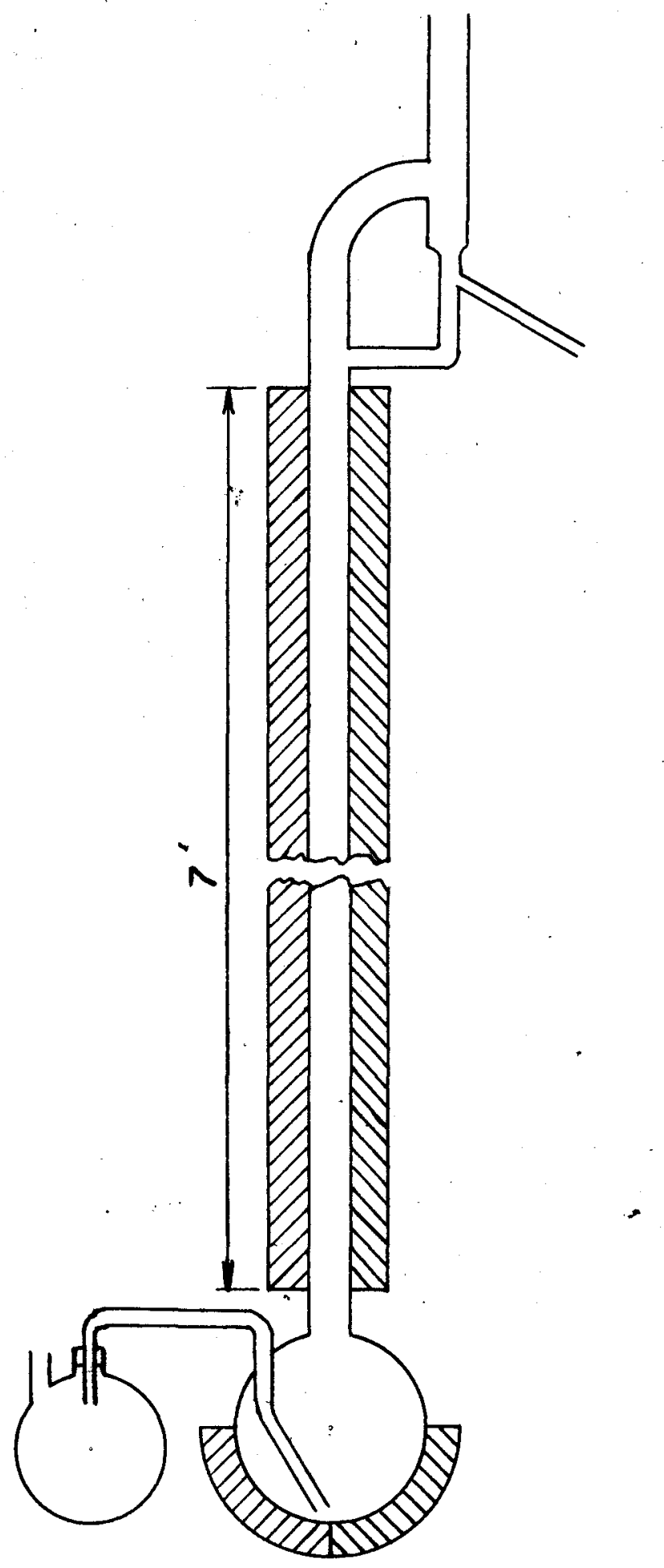

rigure 3. Betoh D1st1llatl on Column. 
TABLE IV - BATCH DISTILIATION DATA

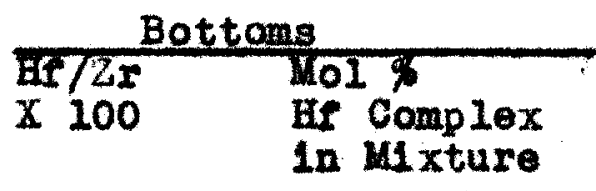

Column at Equilibriun

2.4

1.21

300 gram fraction removed

$2.2 \quad 1.11$

15.5

14.0

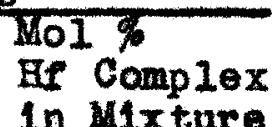

in Mixture

\begin{tabular}{ll} 
HeTzF & Tops \\
$X 100$ & $\begin{array}{l}\text { He Complex } \\
\text { In Mixture }\end{array}$ \\
\hline
\end{tabular}

6.67

1.11

15.5

7.34 
manties on the column, with the temperatures measured with Ironconstantan thermocouplos placod, at intervals, betwoen the boutIng elements and the glass columns. Berl saddle packing, one quarter inch nominal diameter, was selected because of 1 ts large surface area and low erfetional resistance. Before ttachIng the still pot to the column, slow stream of nitrogen was allowed to flow through the column for flfteen minutes to remove all of the air and moisture.

A 2200 gram betch of complex was prepared as described proviously and which filled the two 11 ter bofling flask somewhat more than 50 per cent. It was attempted to bring the column and stlll to operating tempereture ovenly as possible to avold the thermal strains. It was recognized that the temperature of bolling, $360^{\circ} \mathrm{C}$, was approaching the danger point of glass, and extreme care would have to be exerclsed. In splte of all the precautions, considerable breakage occurred during the work, possibly because a $360^{\circ} \mathrm{C}$. temperature in the rlask necessiteted an outer surface temperature t least twenty to twenty-five degrees higher.

Standard taper joints were used in the original distillation apparatus, but these were unsatisfactory for two reasons:

(1) Leaks, whlch apperently were unavoldable, and

(2) Difficulties in taking the joints apart, after long exposure to the complex and heat. Various metbods for sealing the joints were tried in an attempt to prevent leaks, and to permit disassembly at a later de te but none were completely 
satisfactory. The difficulty of teking these joints apart is attributed to (1) reaction of the complex with sulfuric acid to produce zirconium sulfate, and (2) the reaction of the complex with molsture to produce what appeared to be a ceramic material. When the latter was beated sufficiently to permit sof tening of the seal materlal, the glass around these sectlong became brittle. The complex could be observed working its way into the joint and forming wite deposit, which appeared to be reaction compound, causing the major difficulty in separating the joints. This same type of formation occurred whether or not sulfuric acid was prosent and seemed to bo similar to the bydroIy als products.

The difficulties encountered w1th standard taper joints led to the substitution of bell and socket foints wherever standard taper joints falled. Thls substitution did not alleviate all of the trouble with joints, but belped considerably. Taking the ball and socket joints apart bocame fairly easy when the joint was in position a to permit beating below the socket section. The beating apparentiy caused sufficient oxpansion to break the seal formed by the complex and its reaction products. Heating the foint itself did not effect separation, a both parts expanded equally. In the use of ball and socket joints - fine valve grinding compound was tried, for additional seatIng purposes, and was found to be quite good. It was necessary however, to prevent this valve grinding compound from entering the column, as the oll in the valve grinding compound, with the 
complex, produced black flaky solid.

In the inltial operation of the column, it was noticed that a quantity of colorless 11 quid rose in the column and refluxed first in the dividing head. Fumes from the condenser indicated that this meterial was phosphorus oxjchloride. The phosphorus oxychloride gredually became less and as the last of this material was removed through the condenser a white curdy material was deposited on the walls. It was supposed that a portion of this curdy material was from impurities such as a t1 tentum complex, or from hydrolysis products of the zirconium material 1tself. All of these phenomene normaliy took place before any 31 gnificant amount of complex was found in the dividing bead. As the complex in the still approsched boling conditions, more of this curdy solid material appeared and continued to form oven though the temperature of the column was at $360^{\circ} \mathrm{C}$. As the dark fumes of complex rose in the column, the white solld was seemingly dissolved, reeveporated, end pushed up the column ahead of the refluxing 11quid, until it reached the condenser. The refluxing $11 q u i d$ showed a eradueted color chenge, over the length of the column. The complex was a dark green to black 11 quid in the st11l pot; but in higber sections of the column the liquid became amber, fading to pale yollow, and eventually to a clear liquid at the top. The color wa probably from iron impurities in the zirconium tetrachloride remaining in the lower portion of the still and removed by fractionation as the complex moved up the column. Once fairly stable thermal state bad been reached, by regulating power input to the beating 
mantles, period of three hours was considered necessary for the system to reach equilibrium. Accordingiy, the column was operated at total reflux during all of this time. Total reflux was accomplished by allowing the complex in the tops product take off arm to freeze and by keeplng the condenser and return line to the column open with infra-red beating lamps.

At the end of three hours a sample was taken off the condenser by melting the complex in the take off arm and collectIng a specimen of erosbly condensing vapors. By means of a siphon arrangement in side opening of the still pot sample of the bottoms product was withdrawn by application of a partial vecuum.

After the samples were taken, e fraction was removed slowly from the dividing besd t an approximate rate of 2.5 grams per minute. This praction normeliy had welght of about three hundred grams. The rate of removal was very slow, as indicated and it was saumed that equilibrium had been maintained in the column. Therefore, within a short time another series of samples were taken for analysis. Data on the first operations, with analygis are shown in Table IV and plotted on Higure II.

Upon the removal of the still pot from the batch column, after the first equilibrium test run 1 t wa observed that solld ss bad been formed in the bottom of the still pot. Thls layer of solld next to the glass, cut down the beat transfer, and caused dangerous rise in temperature. The formation can and did cause the glass to become over 
heated. On oocasions this overheating of the glass actually resulted in the bottoms being melted from the flask. The welght of the formation was too large to be considered as arising from impurities only, and was supposed to be some decomposition product due to heating of the complex, although it had not been expected.

Experimental Distillations

Due to operating diffloultes, it was found that with the equipment avallable $1 t$ was not feasible to attempt a truiy continuous operation. However, it was desirable to produce zirconium of low hafnlum concentration, and this led to the adoption of a modifled technique.

The complex was prepared in a manner similar to that previously described, in gallon size stalnless steel beakers. Tops were rashloned for these beakers in order to facilitate the distillation of the freshly prepared complex and to remove the non-rolatile portions.

The first experimental column was a simple stripper, with a feed inlet on the top plate and a dividing head as on the previously batoh column (shown in Figure IV).

Freshly prepared and distilled complex was charged Into the hot column through the feed lnlet by siphoning molten oomplex from an auxillary rlask. Heating the foed flask produced sufficlent pressure over the complex to force it through the reed 11 ne and into the column. The bottoms product take off was through a siphon from the still pot and extending in to a recelver, which was connected to a racuum line. When it was desired to remove the bottoms product, a controlled 


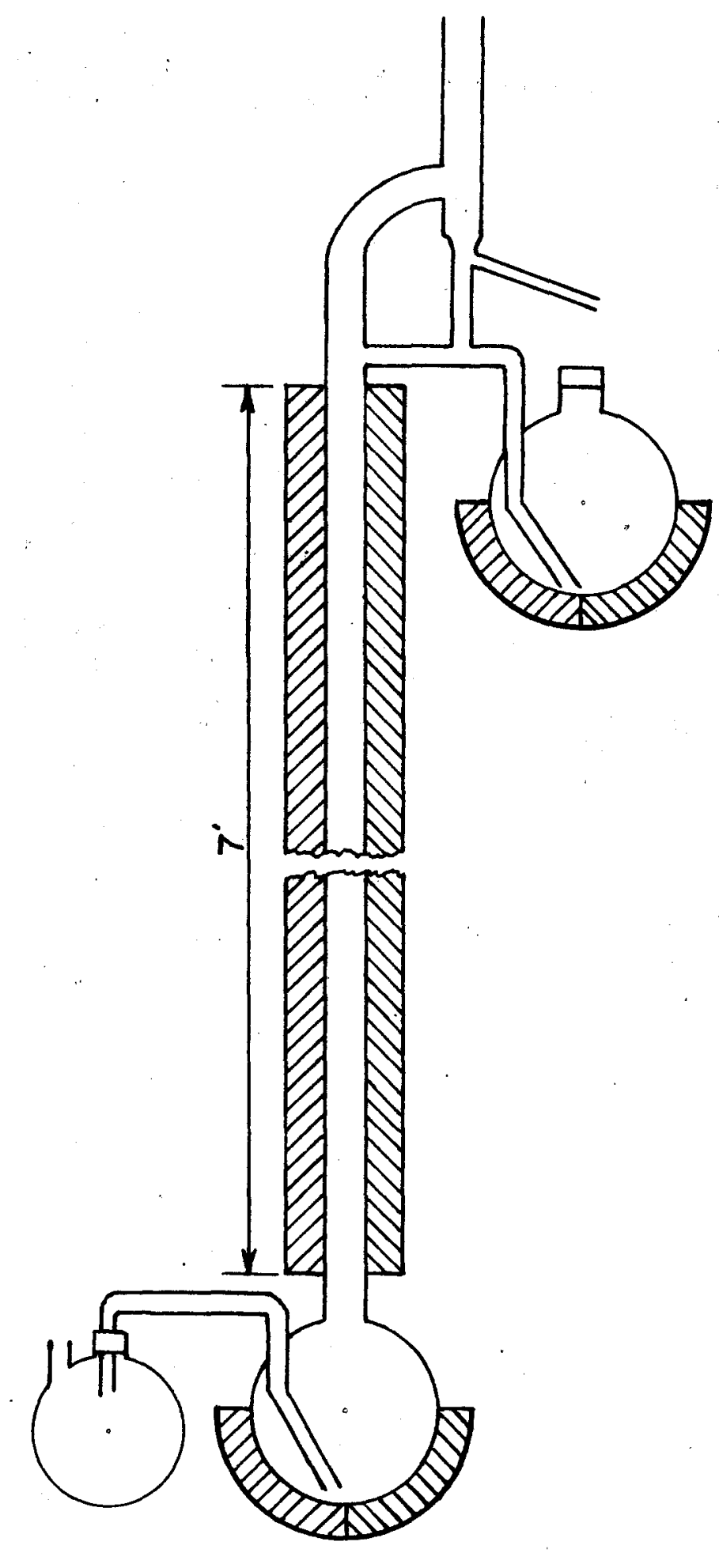

Iigure 4. Stripper Column. 
vacuum on the receiver drew over the required material.

In order to prevent a continuous flow of vapors and/or Ilquid in the auxillary lines, molten complex was frozen in them when the desired amounts had passed. This freezing of the complex in these glass lines of ten caused breakage and interruption of operations. However, no completely satisfactory method of control was found to replace this rather crude procedure. Complex was charged into the column a rate of one thousand grams in thirty minutes and was intermittent a a perlod varying from 30 minutes: to 2 bours was permitted botween recharging. Al though completely continuous operation was desired this was the slowest rate at which 1 t was possible to charge, the column with the equipment avallable and therefore an intermittent operation was obtained. The top product was removed continuousiy at varying rate, averaging approximately three grams per minute. The bottoms was taken off in batches and in an amount roughly equivalent to the quantity of tops removed. The total of the tops and bottoms correaponded to the preceding feed welght when flgured on relatively long time interval. A quantity of complex mounting to approximately fivs hundred cubic centimeters or one thousand grams, remalned In the colum and pot the end of eacb cycle of operations. The operation was repeated after the removal of the bottoms fraction.

The foed inlet for this column was part of the dividing head and probably because of the thermal strains placed on the glass during periods of foeding and the freezing 
of the foed 1ine, the apparatug did not function satisfactorily. The samples that were obtalned gave analyses that showed the deslred separation was not being accomplished. In order to remove the mechanical difficulties of feoding, and to give better separation, it was docldod to make the column taller and place the feed at an intermediate point.

A new column was designed, and is lilustrated in Figure V. This last modification was the one on which the remainder of the experimental work was performed. The column provided the maximum helght of vapor travel which was possible to obtain a it then approched the colling. The column height, exclusive of the still pot and the condenser was nine feet. The feed inlet was placed two feet below the condenser and seven feet above the still pot. This column was operated simliarly to that previously used with one exception. The section of the column above the feed line was operated as partial condenser. By controling the power input in the insulation of this section it was possible to control the amount of vapor which reached the dividing bead. A partial control was thus maintained over the reflux ratio as in this way the amount of product toke off was regulated. It was impossible to maintain the tops product take off a constant rate bowever, as can be soen in the time log.

The time 108 of this series of operations with the analysis of the semples is shown in Table V. The column was operated for three days without a complete shutting down, even 
though diffloulties were encountered with glass breakage. The bottoms product from this continuous operation was contaminated with large quantitios of undesirable compounds, whloh apparently were in the original material as well as the non-distillables whloh formed during operations.

In order to rid the oomplex of these impurities a cleansing distillation was carried out in a thirty plate oldershaw column. As was observed in the packed column the complex on the lower plates was amber, and the color paded to pale yellow and to a clear watery material at the top. By controlling the heat on the st1ll pot, the olear whlte llquid was distilled over leaving all colored material as a residue. Analyses of samples were made spectrographically by a method developed by $C$. Feldman (31). The chemical preparation of the samples for spectrographic analysis was proposed by D. M. Gruen and J. J. Katz (53). 
TABIE V - PIME LOG FOR PACED COLUMN OPERATION

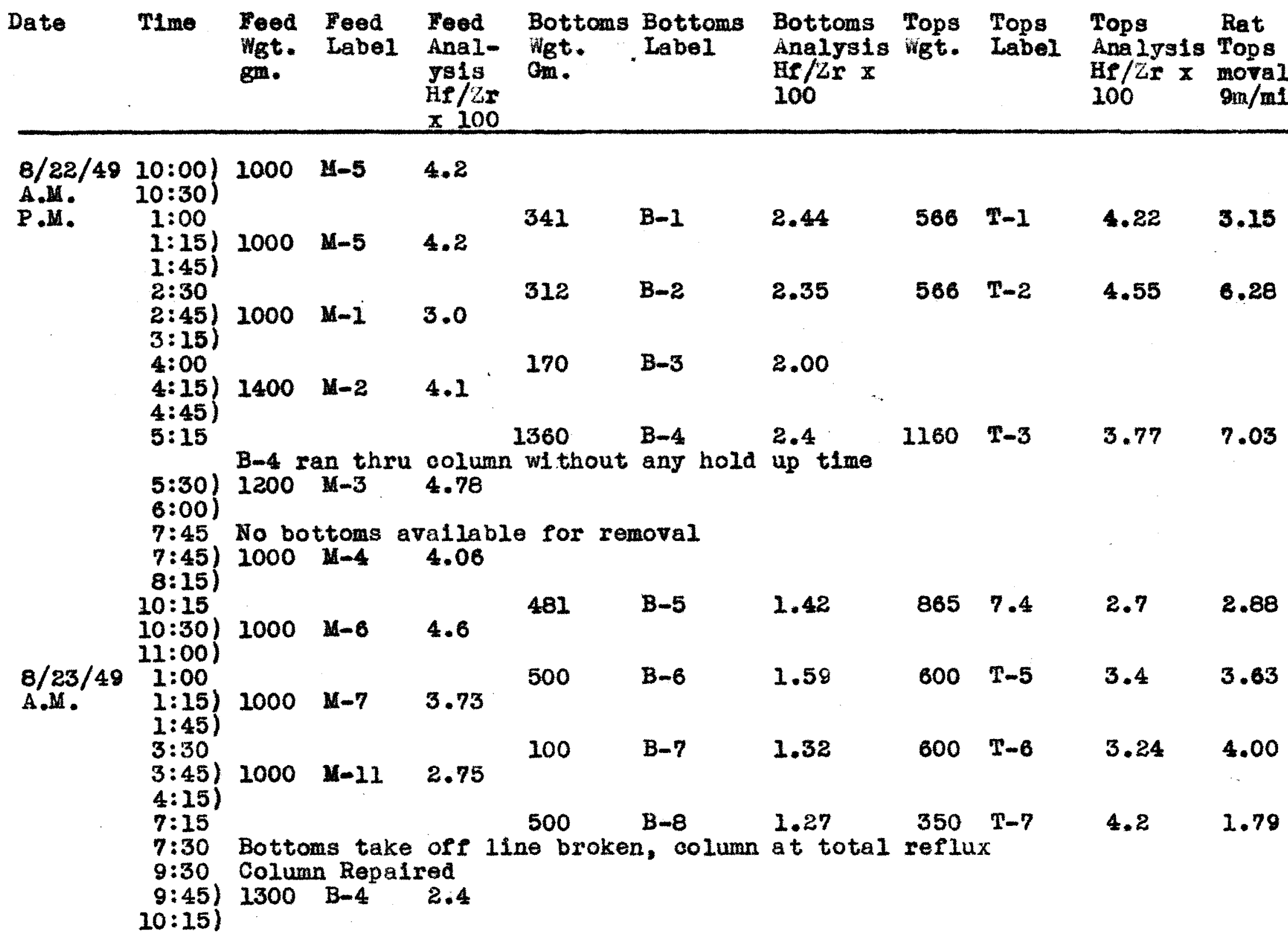


TABLE $v$ (Cont.) - TIME LOG FOR PACKED COLUMN OPERA TION

\begin{tabular}{|c|c|c|c|c|c|c|c|c|c|c|c|}
\hline to & Time & $\begin{array}{l}\text { Feed } \\
\text { get. } \\
\text { gin. }\end{array}$ & $\begin{array}{l}\text { Feod } \\
\text { Label }\end{array}$ & $\begin{array}{l}\text { Feed } \\
\text { Analysis } \\
\mathrm{Hf} / \mathrm{Z} \times \mathrm{X} \\
100\end{array}$ & $\begin{array}{l}\text { Bottoms } \\
\text { igt. } \\
\text { Gm. }\end{array}$ & $\begin{array}{l}\text { Bottoms } \\
\text { Label }\end{array}$ & $\begin{array}{l}\text { Bottoms } \\
\text { Analysis } \\
\text { He/zr X } \\
100\end{array}$ & $\begin{array}{l}\text { Tops } \\
\text { Wgt. }_{\text {gm. }}\end{array}$ & $\begin{array}{l}\text { Tops } \\
\text { Label }\end{array}$ & $\begin{array}{l}\text { Tops } \\
\text { Anelysis } \\
\text { He/zr X } \\
100\end{array}$ & $\begin{array}{l}\text { Rat } \\
\text { Tops } \\
\text { moval } \\
90 / \mathrm{ml}\end{array}$ \\
\hline
\end{tabular}

P.M. $\quad 3: 00$ Column operation started gain

$5: 45 \quad 11400 \quad 4-8 \quad 1.31$

$6: 15$ )

$\begin{array}{lllllll}7.30 & 500 & B-10 & 1.77 & 500 & T-9 & 4.38\end{array}$

$7: 4: 03$
$8: 15$

Feed line broken, column refluxing, no tops removal

8/24/49 1:00 Column repaired, tops fraction coming off

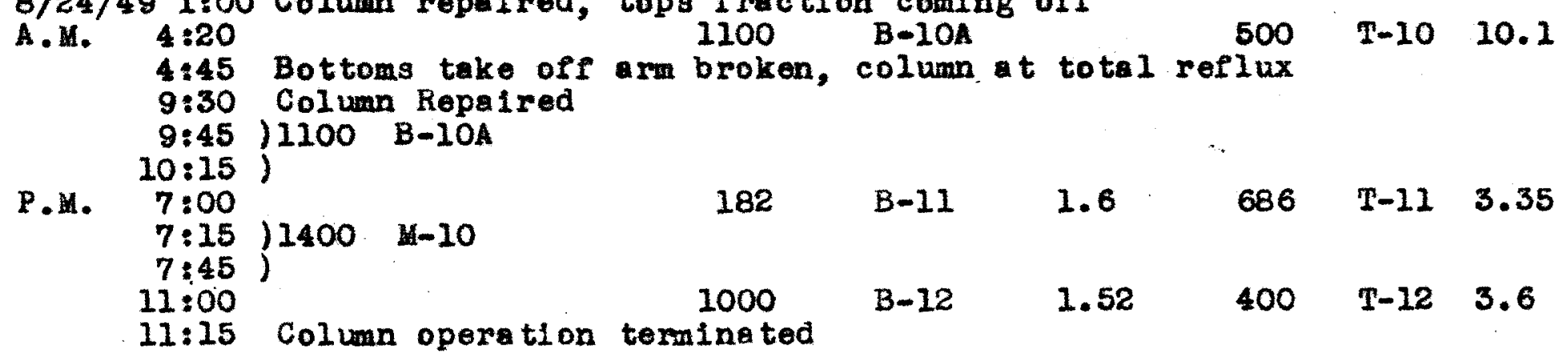




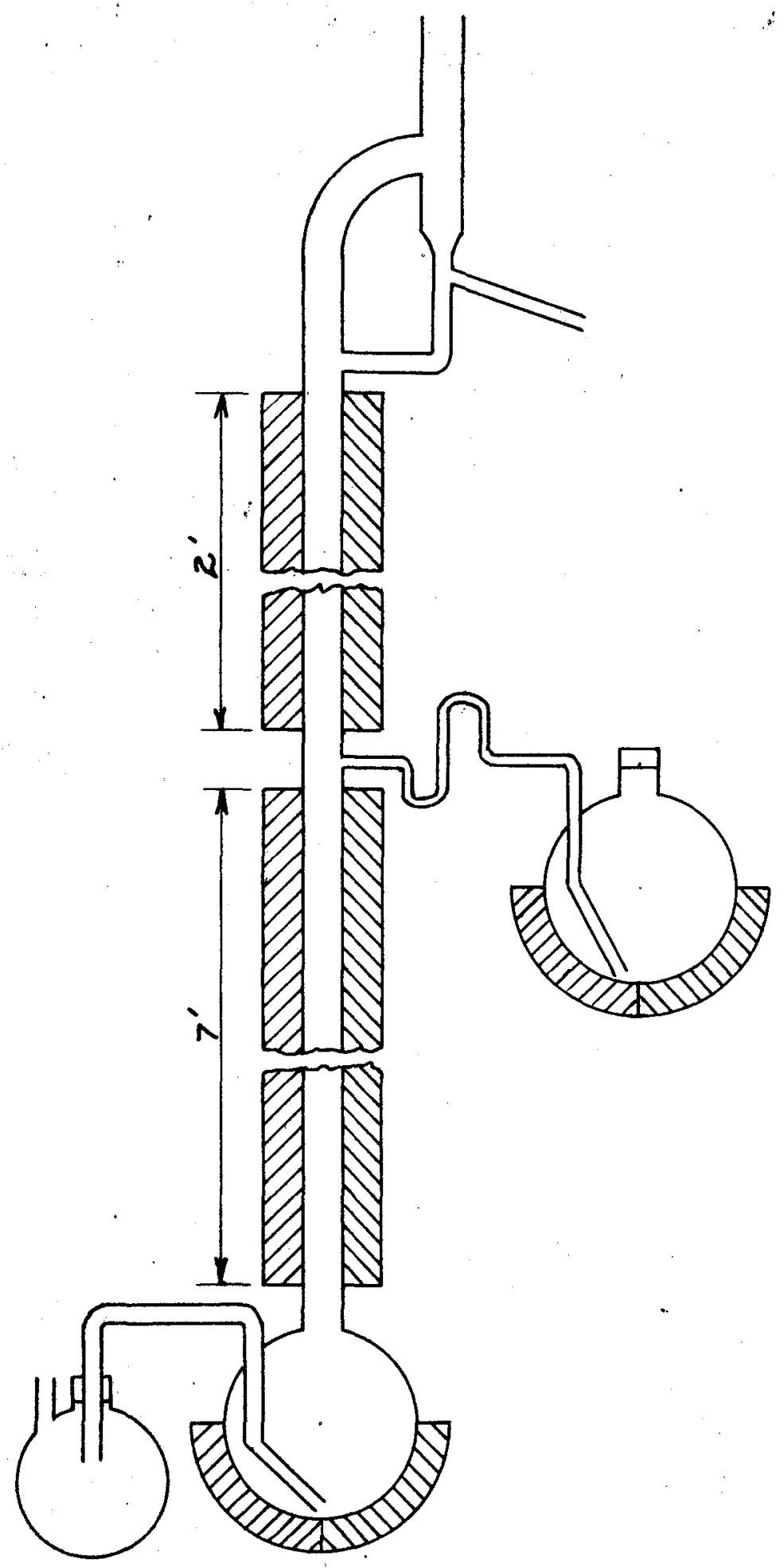


PHYSIOLOGICAL OBSERVATIONS 
The safety precautions necessary in dealing with zirconium tetrachloride and phosphorus oxychlorlde have been pubIlshed and alnce the work here deals primarily with the complex salts, they will not be dealt with here.

The complex formed from these two compounds is both dengerous and unpleasent to work with because of the decomposition producto which result from the reaction of the complex with molsture even in the tmosphere, and which produces primarily hydrochloric acid with posibly some chlorine and phosphine.

Inhaled vapors and fumes cause severe coughing, sore throat, and congestion of the lungs, resulting in a "wheezing". These effects do not appear to 11nger or spread to other parts of the body, and the results of a minor exposure may be thrown off by the body in for dajs. In like manner, the fumes Irritate the mucous membranes of the eyes, creating tears and smarting. This irritation of the eyes persists for some hours after exposure, and boric acid solution should not be used to halt this irritetion. Plain water appears to bring some re11. f, but is not atisfactory.

Fumes and vapors of the complex produce stinging and Irritation of the skin, but if they are not hot, washing with water quickly removes the unpleasantness. If the vapors are hot, burn results but if exposure to hot fumes or vapors is not excessive, only 1 tching and scaling of the skin will occur.

By observing the proper precautions for hydrochlorlc ac1d, phosphorus oxychloride, and for burns, the harm from exposure to the fumes and vapors can be reduced to a minimum. 
There have been no cases of zirconium or hafnium polsoning reported in the 11 terature, the toxicity of each is considered very low, and the effect is not cumulative (32). 
SUMMARY AND CONCLUSIONS 
The preparation of zirconfum, hafnium complex mixturos was found to be comparatively simple, and the melting and bolling points of the complexes compared favorably with those reported by other investigators. The phosphorus oxychloride complex bowever does not have a true melting point, sof tening at $80^{\circ} \mathrm{C}$. and beginning to flow at $130^{\circ} \mathrm{C}$., and in this respect, act as ter or viscous solution. It was observed that the phosphorus oxychioride complexes were sufficlentls stable to undergo Practional distillation and preliminary investigations indicate that the same is true for the phosphorus pentachloride complexes. Results indicate nel ther the formulae $2 \mathrm{MCl}_{4} \cdot \mathrm{POCl}_{3}$ and $2 \mathrm{MCl}_{4} \cdot \mathrm{PCl}_{5}$ as proposed by $\mathrm{Van}$ Arkel and De Boor nor $1.5 \mathrm{MCl}_{4}$. $\mathrm{POCl}_{3}$ and $1.5 \mathrm{MCl}_{4} \cdot \mathrm{PO}_{5}$ a proposed by Gruen and tatz are exact for 1 t has been observed that upon successive beating and cooling some gaseous docomposition material was removed from the mixture. This, and the presence of hoavy non-distillable substance in the bottom residue indicate that the complex, if an actual compound, is not completely stable. The results of the batch distillation investigation parallel those of Gruen and Katz and those of Foote Mineral Company. If corresponding tops praction and bottoms residue values are chosen Prom the data of Gruen and Katz and Foote Mneral Company, an average number of theoretical plates of approximately 18 is obtalned from Figure I when using oldershaw columns containing fifty actual plates on one such plate spacing, therefore the plate efficlency is approximately 36 per cent. An H.E.T.P. of five inches was obtained for a 
one inch diameter column with $1 / 4$ inch berl saddles with on actual height of packing of 80 inches. This 5 inches H.E.T.P. compares with reported values of 1 inch to 8 inch obtalned by other investigators, with various types of packing on similar sized colunns. (2)(34)(35). It has been shown that a column working with this material must have positive controls and should be constructed of terial able to wltbstend considerable heat. The operations during this investigation indicate that continuous distilletion procedure for the seperation of hafnium from zirconium is quite fessible. 
BIBLIOGRAPEY 
(1) Arend, A. G., Chem. Products, 11, 30-2 (1948)

(2) Bragg, L. B., Trans, tmer. Inst. Chem, Engr., 37, 19-50 (1941)

(3) Bradt, W. E., and LIndford, H. B., Trans. Am. Hlectro Chem. Soo., 70, 431-39 (1936)

(4) Brauner, B., Chem. and Ind., 42, 884-5 (1923)

(5) Coster, D., Physica, 3, 133-41 (1923).

(6) Coster, D., and Hevesy, G. ron, Nature, 111, 79, (1923)

(7) Ibid 182

(8) Ib1d 252

(9) Coster, D., and Hevesy, G. ron, U.S., 1,580,650 (1924)

(10) Coster, D., and Heresy, G. ron, U.S., 1,586,241 (1924)

(11) Coster, D., and Hevesy, G. von, U.S., 1,618,960 (1924)

(12) Coster, D., and Hevesy, O. von, U.S., 1,666,440 (1924)

(13) Coster, D., and Heresy, G. von, Can., 275,682 (1927)

(24) Coster, D., and Heresy, G. ron, Can., 275,683 (1927)

(15) Coster, D., and Hevesy, O. von, Can., 275,684 (1927)

(16) Coster, D., and Hevesy, G. von, Can., 275,685 (1927)

(17) Coster, D., and Hevesy, G. von, Can., 275,686 (1927)

(18) Coster, D., and Hevesy, G. ron, Can., 275,687 (1927)

(19) Chambers, G. H. Metals and Alloys, 4,199-201 (1933)

(20) DeBoer, J. H., Z. Anorg. Allgem. Chem., 150,210-6 (1926)

(21) DeBoer, J. H., Ind. Eng. Chem., 19, 1256-9 (1927)

(22) DeBoer, J. H. Z. Anorg. Allgem. Chem., 165,1620 (1927)

(23) DeBoer, J. H., Can., 275,696 (1927)

(24) DeBoer, J. H., U.S., 1,666,811 (1927)

(25) DeBoer, J.H., U.S., 1,771,557 (1927) 
(26) DeBoer, J. H., and Van Arkel, A. E., Ger., 476,099 (1925)

(27) DeBoer, J. H., and Van Arke1, A. E., Brit., 260,082 (1925)

(28) DeBoer, J. H., and Van Arkel, A. E., U. S., 1,709,781 (1925)

(29) DeBoer, J. H., and Broos, J., Z, Anorg. Allgem. Chem., 187, 190-2 (1930)

(30) Deutsohe Garglublicht-Auer, Ger., 492,756 (1923)

(31) Drophy, D. H. and Davey, W. P., Phys. Rev., 25, 882-3 (1925)

(32) Fairhall, I. T., Phys101. Rev., 25, 182-202 (1945)

(33) Feldman, C., Anal. Chem., 21,1211-15 (1949)

(34) Ienske, M. R., Tongberg, C. O. and Lawrosk1, S., Ind. Eng. Chem., 29, 957-8 (1937)

(35) Fenske, M. R., Tongberg, C. 0., Qulggie, D., Ind. Eng. Chem. 26, 119-77 (1934)

(36) F1sher, W. and Zumbusch, M., Z. Anorg. Chem., 252, 249-55 (1944)

(37) Fisoher, W, and Zumbusoh, M., Chimle and Industrie, 53, 321 (1945)

(38) Foote Mineral Co., Teoh. Report No. 1 (NYO0-60) (1949)

(39) Foote Mineral Co., Tech. Report No. 2 (NYOO-67) (1949)

(40) Gloellampenfabrleken, N.V.P., Brit., 219,024 (1923)

(41) Gloellampenfabrleken, N.V.P., Brit., 219,327 (1923)

(42) Gloe1lampenrabrleken, N.V.P., Br1t., 219,983 (1923)

(43) Gloellampenfabrleken, N.V.P., Brit., 220,358 (1923)

(44) Gloellampenfabrieken, N.V.P., Br1t.; 220,936 (1923)

(45) Gloellampenfabrieken, N.V.P., Brit., 221,802 (2923)

(46) Gloellampenfabrioken, N.V.P., Brit., 238,543 (1924)

(47) Gloeilampenfabrieken, N.V.P., Brit., 258,243 (1925) 
(48) Gloellampenfabrieken, N.V.P., Brit., 260,062 (1925)

(49) Gloeilampenfabrieken, N.V.P., Brit., 266,800 (1925)

(50) Oloollampenfabrloken, N.V.P., Dutch, 15,181 (1926)

(51) Gloellampensabrieken, N.V.P., Dutoh, 16,955 (1927).

(52) Gloellampenfabrieken, N.V.P., Dutch, 16,956 (1927)

(53) Gloel lampenfabrieken, N.V.P., Dutoh, 17,742 (1928)

(54) Gloellampenfabrleken, N.V.P., Frenoh, 749,383 (1933)

(55) Gloellampenfabrleken, N.V.P., U. S. 1,582,860 (1924)

(56) Gruen, D. M., and Katz, J. J., A. N. L. 4269 (1949)

(57) Heresy, G. von, Chem. News, 127 33-34 (1923)

(58) Hevesy, G. von, Current Sc1., 5, 236-40 (1936)

(59) Hevesy, G. von, Nature, 115, 335-6 (1925)

(60) Hevesy, G. von, and Cremer, 1., Z. Anorg. Allgem. Chem., $190,123-44(1930)$

(61) Hevesy, G. ron, and Dullenkopt, W., Z. Anorg. Allgem. Chem., 221, 161-6 (1934).

(62) Hevesy, G. von, and Jantzen, V. T., J. Chem. Soc., 123, 3218-23 (2923).

(63) Hevesy, G. von, and Jantzen, V. T., Chem. News, 127, $353-5(2923)$

(64) Heresy, G. von, and Jantzen, V. T., Z, Anorg. Allgem. Chem., 136,387-92 (1924).

(65) Hevesy, G. von, and Madsen, E., Z. Angew. Chem., 38, 228-30 (1925)

(66) Hevesy, G. Von, and Wegner, H. O., Z. Anorg. Allgem, Chem., 191, $194-200(1930)$ 
(67) Honigschmid, O. and Zinth, E., Z. Anorg. Allgem. Chem., $140,335-36(1924)$

(68) Howard, J. H., J. Chem. Ed., 17,265-7 (1940)

(69) Kenda 11, J., Sc1ence, 67, 163-7 (1928)

(70) rondall, J., and west, W., J. Am. Chem. Soc., 48, 2619-26 (1926)

(71) Kroll, J., Trans. Electrochem. Soc. 89, 12 pp. Preprint (1946)

(72) Kroll, W. J., and schlechten, A. W., U. S. Bur. Mines Inform. C1rc., 7341, $50 \mathrm{pp}$. (1946)

(73) Larson, E. M., t al, Ind. Eng. Cbem., Anal. Ed, 15, 512$15(1943)$

(74) Lilliendabl, W. C., and Rentschler, H. C., Trans. Electro. Chem. Soc., 9l, 10 pp. Preprint (1947)

(75) Warden, J. W., and RIch, M. N., U. S. Bur. Mines Bull., $186,146(1921)$

(76) Haula, M., et al, Compt. rend., 180, 1377-80 (1925)

(77) Mellor, J. H., "Comprehensive Treatise on Inorganic and Theoretical Chemlstry", Vol. VII, P. 98 (1927)

(78) Ib1d, P. 166

(79) Melster, G., Metal Progress, 53, 515-20 (1948)

(80) Powell, A. R., and schoeller, W. R., Analyst, 55, 605-12 (1930)

(81) Prandtl, W., U. S., 1,976,293 (1934)

(82) Prandt1, W., Gor., 546,215 (1931)

(83) Prandtl, W., Z. Anorg. Allgem. Chem., 208,420-6 (1932)

(84) Prandtl, W., Mayer, G., Buttner, L., Z. Anorg. Allgem. 
Chem., 230, 419-26 (1937)

(85) Rahlfs, 0. and Fisoher, $w, 2$. Anorg. Allgem. Chem. 211, 350$360(1933)$

(86) Rioh, M. N., U. S. 1,856,264 (1927)

(87) Robinson, C. S, and Gilliland, E. R., "Elements of Fractional Distillation", 3rd Ea1tion, pp 81-131 (1839)

(88) Ib1d pp 238-252

(89) Schumb, W. C. and Plttman, F. K., Ind. Eng. Chem., Anal. Ed., 14, 512-15 (1942)

(90) Tyler, P. ., U. S. Bur. Mines Inform. Circ., 645711 pp, (1931)

(91) Van Arkel, A. E., and DeBoer, J. H., Can., 275,688 (1927)

(92) Van Arkel, A. B., and DeBoer, J. H., Can., 275,689 (1927)

(93) Van Arkel, A. E., and DeBoer, J.H., Can., 275,690 (1927)

(94) Van Arkel, A. E., and DeBoer, J. H., Can., 275,691 (1927)

(95) Van Arkel, A. E., and DeBoer, J. H., Can., 275,692 (1927)

(96) Van Arkel, A. E., and DeBoer, J. H., Can., 275,693 (1927)

(97) Van Arkel, A. E., and DeBoer, J. H., Can., 275,695 (1927)

(98) Ven Arke1, A. E., and DeBoer, J. H., U. S., 1,582,860 (1924)

(99) Van Arke1, A. E., and DeBoer, J. H., U. S., 1,618,494 (2924)

(100) Van Arkel, A. E., and DeBoer, J. H., U. S., 1,666,800 (192̇)

(101) Van Arkel, A. E., and DeBoer, J. H., U. S., 1,718,616 (1925)

(102) Van Arkel, A. B., and DeBoer, J. H., Z. Anorg. Aligem.

Chem., 141, 289-96 (1924)

(103) Van Arkel, A. B., and DeBoer, J. H, Z, Anorg. Allgem. Chem., 148, 345-50 (1925) 
(104) Von Zeppolin, H., and Telchman, L., U. S. 2,214, 211 (1942)

(105) Walker, W. W., Lew1s, W. K., McAdams, W. H., and 01lliland, E. R., "Principles of Chemical Engineering" 3rd Edition, p 526 (2937)

(106) Wllliard, H. H., and Freund, H., Ind. Eng. Chem., Anal. Ed., 18, 195-7 (1940) 
Th1s Research Was Made Possible

Through A fellowship Grant From

The Univeraity of Loulsville Institute of Industrial Research

As A Portion of Contracted Research with

The A tomic Energy Commision. 
PART II AN ENGINEERING APPRAISAL OF ALUMINUM STRUCTURAL MATERIALS 
TABLE OF CONTENTS

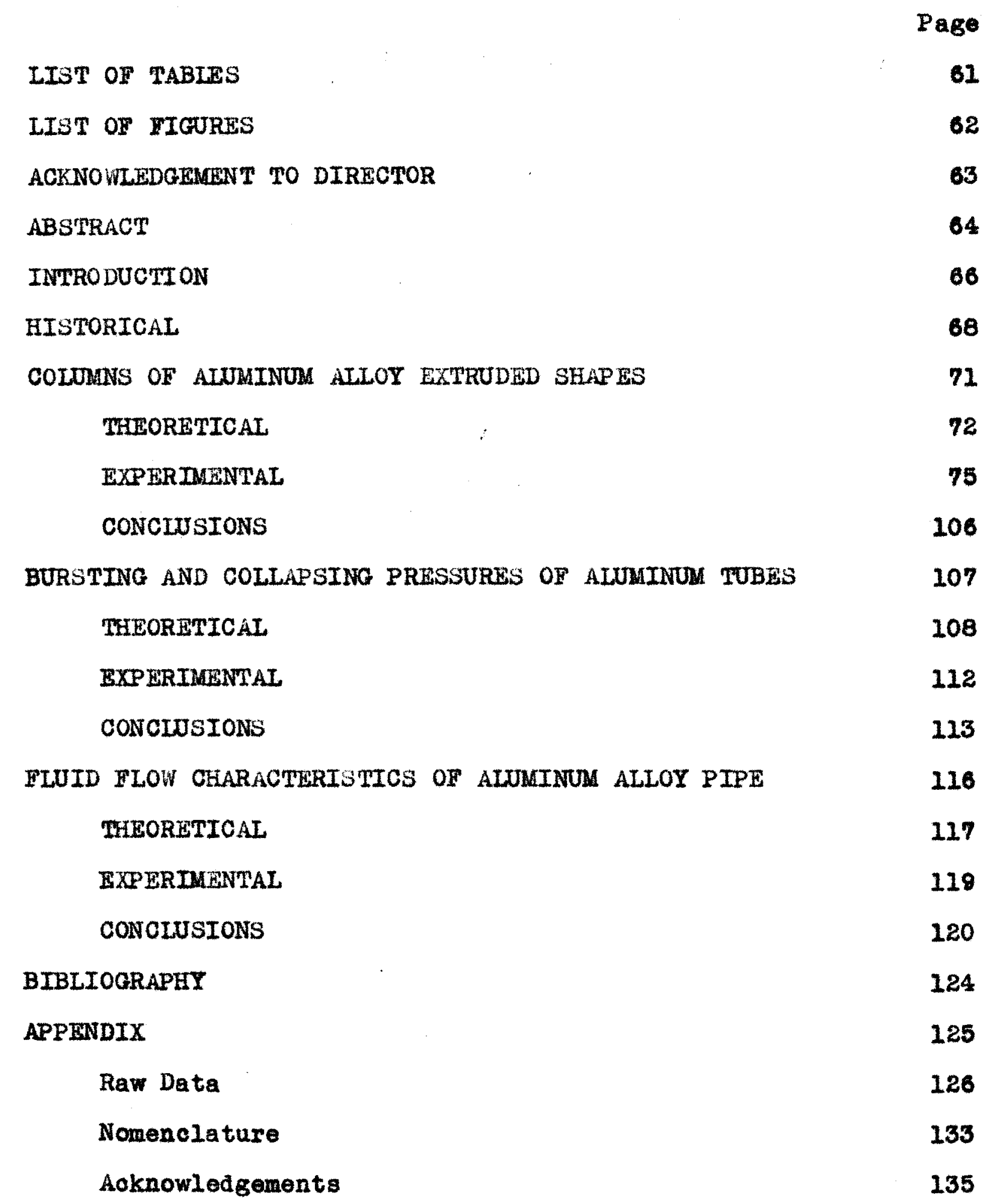




\section{IIST OF TABLES}

TABLE

Pago

I Streas-Strain Data

77

II Materials and Sizos of Columa Tested

84

III Column Data 3s-0 Tublng, 0.065 In. $x 1.00$ In. 85

IV Column Data 3S-H14 Tubing, 0.061 In, $x 1.3125$ In. 86

$v$ Column Data 3s-B14 Tublng, 0.125 In. $x 1.5625$ In. 87

VI Column Data R361-D Tubing, 0.194 In. $x 1.58$ In. 88

VII Column Data R361-0 Tublng, 0.254 In. $x 1.75$ In. 89

VIII Column Data Rs61-T4 Tublng, 0.238 In. $x 1.718$ In. 90

IX Column Data R361-14 Mubing, 0.064 In. $x 1.00$ In. 91

$X$ Colum Data R361-T6 Tublng. $0.238 \mathrm{In} . \times 1.625$ In. 92

XI Colum Data $638-1$ Tublng. 0.3125 In. $\times 1.875$ In. 93

XII Colum Data 8361 -T Channe1, 6 In. $x 0.437$ In. 94

XIII Column Data R361-T Angle, 1-1/4 In. $x$ 1-1/4 In. $x$ $3 / 16$ In.

$X$ IV Columin Data R361-T Anglo, $8-1 / 2$ In, $x$ 2-1/2 In. $x$ $1 / 4 \mathrm{In}$.

96

XV Colum Formulas

106

XVI Bursting Test Data and Results

114

XVII Collapaing Teat Data and Fesults

115

XVIII FIow Date for Two-Inoh P1po

122

XIX PIow Data for a Four-Inoh P1po 
LIST OF FIGURES

FI GUKE

1 Stress-Strain Diagram for $3 S-0$

2 Stresa-Strain Diagram for R361-0

3 Stress-Strain Diagram for $R 361-T 4$

4 Stress-Strain Diagram for R36I-T6

5 Stress-Strain Diagram for $63 \mathrm{~S}-\mathrm{T}$

6 Unit Load vs. Slenderness Rat1o for 3 S-0 Tubing Columns 0.065 In. $x 1.00$ In.

7 Unit Load vs. Slenderness Ratio for 3S-H14 Tubing Columns 0.061 In. $x 1.3125$ In.

8 Unit Load va. Slenderness Rat1o for 3S-H14 Tubing Colums 0.125 In. $x 1.5625$ In.

9 Un1t Load vs. Slenderness Rat1o for R361-0 Tubing Columns 0.254 In. $x 1.58$ An. and 0.194 In. $x 1.75$ In. 100

10 Unit Load vs. Slonderness Rat1o for R361-T4 Tubing Columns 0.238 In. $x 1.718$ In. and 0.064 In. $x$ $1.00 \mathrm{In}$.

11 Unlt Load vs. Slenderness hat1o for H361-T6 Tubing Colums 0.238 In. $x 1.625$ In.

12 Unlt Load vs. Slenderness hatlo for 636-T Tubing Columns 0.3125 In. $x 1.875$ In.

13 Unit Load vs, SIenderness Rat1o for P361-T Channel Columns 6 In. $x 0.437$ In.

14 Unit Load vs. Slenderness Rat1o for k361-T Angle Colums 1 In. $x$ It In. $x 3 / 16$ In. and $2 \frac{1}{2}$ In. $x$ $2 \frac{1}{8} \operatorname{In} . x$ in.

15 Friction Factor va. Reynolas Number for 2 In. and 4 In. PIpo 
The author wishes to acknowledge

the kind assistance and belpful guidance

$$
\text { of Prof. W. B. Wend tho }
$$

directed this portion of the research. 
ABSTRACT 
Aluminum tubing was tested to determine the characteristic column strengths, bursting strengths, collapsing pressures, and resistance to pluid flow.

Results of column testing established formulee showing relationship between ultimate unit load, jield point of material, and slendemess ratio. The long column formula or Euler formula was assumed to hold true above the critical slendernoss value. Yield points of materials were obtained by plotting the results of compression tests or stress-strain curves.

The bursting strengtbs of aluminum tubes were obtained by means of a high prossure pump. These values agree quite closely with the Barlow formula.

The results of collapsing pressure tests although agreeing well within themselves do not check closely with $\mathrm{M}$ moshenko's formula.

The fluld flow investigation resulted in friction factors differing slightly for the 2 inch and 4 inch pipe. In general the data were well within the range of accepted values for comercial pipe and smooth tubes, the data for the 2 inch plpe approaching that for smooth tubes and the data for 4 inch plpe approaching values for comnerolal pipe. 
INTRODUC TION 
The work presented in this report was conducted at the University of Loulsville Institute of Industrial Research under a contract with the Reynolds Metals Company of Loulsville, Kentucky. A desire by the Reynolds Metals Compeny to contribute to the knowledge of aluminum column design, collapsing and bursting of aluminum tubing, and fluld flow characteristics of aluminum pipe prompted the undertaking.

Lmpirical formulae for the design of concrete, steel, and wood columns are well establiabed. However, similar expressLons for aluminum columns are not so well known primarily because of the relatively recent advent of aluminum and 1 ts alloys a structural materials. Likewise, in the fleld of fluid transportation 11ttlo information is avaliable on bursting and collapsing pressures or the frictional resistance of aluminum tubing to flowlng flulds.

The increased use of aluminum in structures as well as in the transportation of fluids bas emphasized the need for the design data and mathematical relations established and confirmed in these studies.

Three major phases of the investigation are presented and separately discussed:

Column Testing of Aluminum Alloy Extruded shapes. Bursting and Collapsing of Aluminum Alloy Tubing. Fluid Plow Characteristics of Aluminum Alloy PIpe. 
HI STORICAL 
At the beginning of the 19 th Century aluminum was 8 laboratory curiosity havin no comercial significance. It remained so until the latter part of the Century when Wartin Hall developed bis now famous electrolytic process for the seperation of metallic aluminum from 1 ts oxide ore.

This development brought aluminum into commercial production, but because of 1 ts softness and lightness several decades went by with comparatively few uses. some of these uses were as kitchen utenglis and for decorativo purposes.

However, in 1898 an Austrian named Schwartz constructed an alrship with aluminum structural members. It was destroyed on 1 ts firgt landing, but it was only two years later that Zoppelin launcbed his first rigld alrship, which was bullt of structural Iuminum. The structural members were Al-Zn alloy, non-heat treated, but by the standards of that day they functioned satisfactorily.

It was not until 1909 that the first successul heat treatable alloy was developed. This was the allog which has come to be known as duralumin and was developed by Alfred Wilm. The explanation of this heat treating effect by $P$. D. Merica led to new metallurglogl principle, which later became important in other metallurglcal fields.

Commercial introduction of heat treatable alloys awalted the end of World War $I$. With their development the guaranteed jield strength of aluminum lloys more than doubled in 20 years. Th1s led to alloys of 60,000 pal tensile strength and $20 \%$ elongetion, which is comparablo with structural steel. 
Prior to World War II practically all of the structural aluminum produced was utilized by the alrcraft industry. Only a small percentage went to other types of structures most of which were experimente1. However, the war brought on increased production and greater knowledge which led to lower prices and placed aluminum in competition with all structural materials. Aluninum alloys of hieh corrosive resistance, which retain their strength bave led to new uses and almost unlimited opportunities. The first section of aluminum pipe ines have been 1ald, since World War II, In the ofl flelds of Loulsiana and experimental work is under way to use it in 011 well casings. These are only two of the numerous use to which aluminum structural alloys are belng adapted. 
COLUMN TESTING OF ALUMTNOM ALLOY EXTRUDED SHAPES 
THEORETICAI

Any object which undergoes axial loading is known as a compression member. These compression members will bend even with axial loads. When a compression member is so slender that the allowable end load must be reduced because of the bending stresses, it is termed a column.

It has been the object of the column evaluation work to determine a mathematical expression for the loading charaoteristics of columns as defined above.

Columns may be divided into two classes: long columns and short columns. Long columns have been examined mathematioally and a rigorous equation developed by Euler as early as 1757. They are defined as columns which fail because of laok of stiffness, inelastiolty, and the ultimate load being reached before the average stress has passed its proportional limit.

One form of Euler's Equation 1s:

$$
P / A=\frac{R^{2} E}{(I / r)^{2}}
$$

Where:

$$
\begin{aligned}
& P=\text { total load in pounds. } \\
& A=\text { area In square inches. } \\
& E=\text { modulus of elasticity. } \\
& L=\text { length in inohes (effective). } \\
& I=\text { radius of gyration in inches. }
\end{aligned}
$$

This equation is applioable to all columns as long as the proportional limit is not exceeded by the load on the column. This report, however, is not primarily concerned with the long or 
Euler columns, as they are sometimes called, but is concerned with the short column.

Short columns moy be defined as those in which stresses throughout the column have exceeded the proportional Iimlt of the material long beiore the ultimate load is reached. This action brings about a considerable amount of inelastic action durlng the process of loading. While the theory of long columns has been known for several hundred years, it was not until the present century that short columns were bendled on ational basis, by Considere, Engesser, and others. The mathematical treatment, however, does not lend 1 tself to practical design and, therefore, many emplrical equetions have been devised for terials in the short colum range.

Aluminum members have the grotest use where light weight is advantageous, particularly in the alrcraft industry, and in thia fleld, equations following the experimental results comparatively closely are essential. Accordingly, many complicated equations have been devised. With the decrease in the cost of luminum it is tending to come into competition wi th many other structural materials emphasizing the need of simple design formulae. The two types of equations that are most frequently used in the short column range are the parabolic and stralght line forms s shown below. Straight Line Equation:

$$
P / A=D-B(L / r)
$$

Parabolic Equation:

$$
P / A=D-C(L / r)^{2}
$$


Where:

$D=P / A$ intercept where $L / x=0$

$B$ and $C=$ Empirically determined constants

These equations must follow experimentel results and they must e1 ther meet or intersect the Euler Equation. The point of meeting or intersection is known as the critical point, or the critical slenderness-ratio. For a slenderness-retio above that point, the colums are long or Euler columns, for values below the critical, the columing short.

The slenderness ratio 13 dependent upon (a) physical dimensions, and (b) the method of fixing the ends or the end conditions. The end-fixity ha been incorporated into the slenderness ratio with the factor $K$ converting the slendernessratio to an effective slenderness retio (K) $(\mathrm{L} / \mathrm{r})$. It has been ahown that for columng of round or plnned-end conditions, the value of $\mathrm{K} 1 \mathrm{i} 1,1.0$. the entire column bends when loaded. For fixed ends, $K=0.5$ which means that only one half of the total length undergoes bending when loaded. When one end is fixed and one end 15 pinned or round, $K=0.7$. 
EXPERIMENTAL

The column testing was conducted on a Baldwin Southwark Tosting hachine equipped with a Tate Emery lond indicator. The dial has three scales; (I) 0 to 40,000 Ibs.; (2) 0 to 160,000 Ibs.; (3) 0 to 400,000 Ibs. The rate of loading of test specimens wa $2000 \mathrm{lba} / \mathrm{mIn}$, except for fow specimens of amall croas sectional area which were loaded as constantiy and a slowly as possible.

To obtain a pinned end, spherical nosed hardened circular steel plate was used. Thls assembly was not frictionlesa, but results in proliminary testing justified its use. To obtain a fixed end, a series of bras busbings were used to fit tightly to the specimen and clamped into steel ring bolted to a large steel plate. For flxed ends for the channel and angle columns steel blocks clamped into position were used.

The colums were placed in the machine and by means of a level and tripod to support the specinens, under a glight load they were adjusted to a ertical position. The tripod was removed before actual testing was started. The loading was then begun and continued unt1l fallure, as indicated by revereal of the direction of travel of the loading needie. Where possible, three specimens. were tested for each length and end condition. It was apparent that the ultimate strength of the materlal would be belpful in stablilzing graphical representetions of the data in the register of low values of $L / r$. Th1s value was determined by the use of strain gage data in plotting a 
stress-strain curve. Such da ta were obtained from tests made with RIeble Testing Lachine, Mechanical Type, 100,000 Ib. capacity, in the materiala testing laboratory of the University of Louisvilio, C1vil Engineering Department. These deta are shown in Table I and Figures 1 through 5.

The columns a tested included the terials and shapes as shown in Pable II and specifled by the Reynolds Metels Company. Test results for each alloy and eacb shapé were plotted a stralght line for all values of the slenderness ratio above and below the critical and are shown in Tables III through XIV and FIgures 6 through 14. 
TABLE I - STRESS-STRAIN DATA

Sample Run Read- $L$ Unit Stress (psi) Unit Strain No. Ing $\frac{1}{i}$

\begin{tabular}{|c|c|c|c|c|c|}
\hline \multirow[t]{2}{*}{$\begin{array}{l}35-0 \\
0.065 \mathrm{ln} . \\
1.00 \mathrm{ln} . \\
\text { Tub } 1 \mathrm{ng} \mathrm{g}^{*}\end{array}$} & $x^{1}$ & $\begin{array}{l}1 \\
2 \\
3 \\
4\end{array}$ & 12 & $\begin{array}{r}2,630 \\
5,260 \\
7,900 \\
10,550\end{array}$ & $\begin{array}{r}0.000133 \\
.000166 \\
.002560 \\
.009400\end{array}$ \\
\hline & 2 & $\begin{array}{l}1 \\
2 \\
3 \\
4\end{array}$ & 12 & $\begin{array}{r}2,630 \\
5,260 \\
7,900 \\
10,550\end{array}$ & $\begin{array}{l}0.00010 \\
.000166 \\
.002660 \\
.00957\end{array}$ \\
\hline \multirow[t]{2}{*}{$\begin{array}{l}\text { R361-0 } \\
0.194 \text { in. } \\
1.58 \text { in. } \\
\text { Tubing }\end{array}$} & $x^{1}$ & $\begin{array}{l}1 \\
2 \\
3 \\
4 \\
5 \\
6\end{array}$ & 10 & $\begin{array}{r}1,250 \\
2,500 \\
3,750 \\
6,250 \\
8,750 \\
9,600\end{array}$ & $\begin{array}{l}0.0000666 \\
.000200 \\
.000400 \\
.0021 \\
.00717 \\
.0085\end{array}$ \\
\hline & 2 & $\begin{array}{l}1 \\
2 \\
3 \\
4 \\
5 \\
6\end{array}$ & 10 & $\begin{array}{r}1,250 \\
2,500 \\
3,750 \\
5,000 \\
6,250 \\
10,000\end{array}$ & $\begin{array}{l}0.000066 \\
.00020 \\
.000466 \\
.000866 \\
.002040 \\
.00953\end{array}$ \\
\hline \multirow[t]{2}{*}{$\begin{array}{l}\text { R361-T4 } \\
0.238 \text { in. } \\
1.718 \text { in. } \\
\text { Tub1rs }\end{array}$} & $x^{1}$ & $\begin{array}{l}1 \\
2 \\
3 \\
4 \\
5\end{array}$ & 10 & $\begin{array}{r}5,440 \\
10,890 \\
16,530 \\
21,780 \\
27,220\end{array}$ & $\begin{array}{c}0.000567 \\
.0013 .0 \\
.00173 \\
.00323 \\
.00833\end{array}$ \\
\hline & 2 & $\begin{array}{l}1 \\
2 \\
3 \\
4 \\
5\end{array}$ & . & $\begin{array}{r}5,440 \\
10,890 \\
16,330 \\
21,780 \\
26,020\end{array}$ & $\begin{array}{l}0.000567 \\
.001133 \\
.00170 \\
.00323 \\
.01000\end{array}$ \\
\hline $\begin{array}{l}\text { R361-T6 } \\
0.238 \text { in. } \\
1.625 \text { in. } \\
\text { Tub1ng }\end{array}$ & $x^{1}$ & $\begin{array}{l}1 \\
2 \\
3 \\
4 \\
5 \\
6 \\
7 \\
8\end{array}$ & 10 & $\begin{array}{r}4,980 \\
9,960 \\
14,940 \\
19,900 \\
24,900 \\
29,875 \\
34,850 \\
39,060\end{array}$ & $\begin{array}{l}0.00534 \\
.0011 \\
.001633 \\
.002233 \\
.0028 \\
.00343 \\
.00444 \\
.01000\end{array}$ \\
\hline
\end{tabular}

* Shape dimensions are expressed as inches wall thiokness $x$ 1nches outside diameter. 
TABLE I - STRESS-STRAIN DATA (Cont'd)

\begin{tabular}{|c|c|c|c|c|c|}
\hline Samplo & $\begin{array}{l}\text { Run } \\
\text { No. }\end{array}$ & $\begin{array}{l}\text { Read- } \\
\text { Ing }\end{array}$ & $\frac{L}{r}$ & Unit Stress (psi) & Unit Strain \\
\hline $\begin{array}{l}\text { R3 } 61-\text { T6 } \\
0.238 \text { in.x } \\
1.625 \text { in. } \\
\text { Tubing }\end{array}$ & 2 & $\begin{array}{l}1 \\
2 \\
3 \\
4 \\
5 \\
6 \\
7 \\
8\end{array}$ & 10 & $\begin{array}{r}4,980 \\
9,960 \\
14,940 \\
19,900 \\
24,900 \\
29,875 \\
34,850 \\
39,060\end{array}$ & $\begin{array}{l}0.000534 \\
.0011 \\
.001633 \\
.00220 \\
.002766 \\
.003366 \\
.0044 \\
.01000\end{array}$ \\
\hline \multirow[t]{2}{*}{$\begin{array}{l}63 \mathrm{~S}-\mathrm{T} \\
0.3125 \mathrm{in} . \\
1.875 \mathrm{in} . \\
\text { Tubing }\end{array}$} & & $\begin{array}{l}1 \\
2 \\
3 \\
4 \\
5 \\
6 \\
7 \\
8\end{array}$ & 10 & $\begin{array}{r}4,540 \\
9,080 \\
13,620 \\
18,160 \\
22,700 \\
27,240 \\
31,780 \\
33,720\end{array}$ & $\begin{array}{r}0.000466 \\
.000833 \\
.001266 \\
.001700 \\
.002166 \\
.002900 \\
.00587 \\
.01000\end{array}$ \\
\hline & 2 & $\begin{array}{l}1 \\
2 \\
3 \\
4 \\
5 \\
6 \\
7 \\
8\end{array}$ & 10 & $\begin{array}{r}4,540 \\
9,080 \\
13,620 \\
18,160 \\
22,700 \\
27,240 \\
31,780 \\
33,720\end{array}$ & $\begin{array}{c}0.000433 \\
.000867 \\
.001300 \\
.001767 \\
.00260 \\
.002933 \\
.00490 \\
.01000\end{array}$ \\
\hline
\end{tabular}




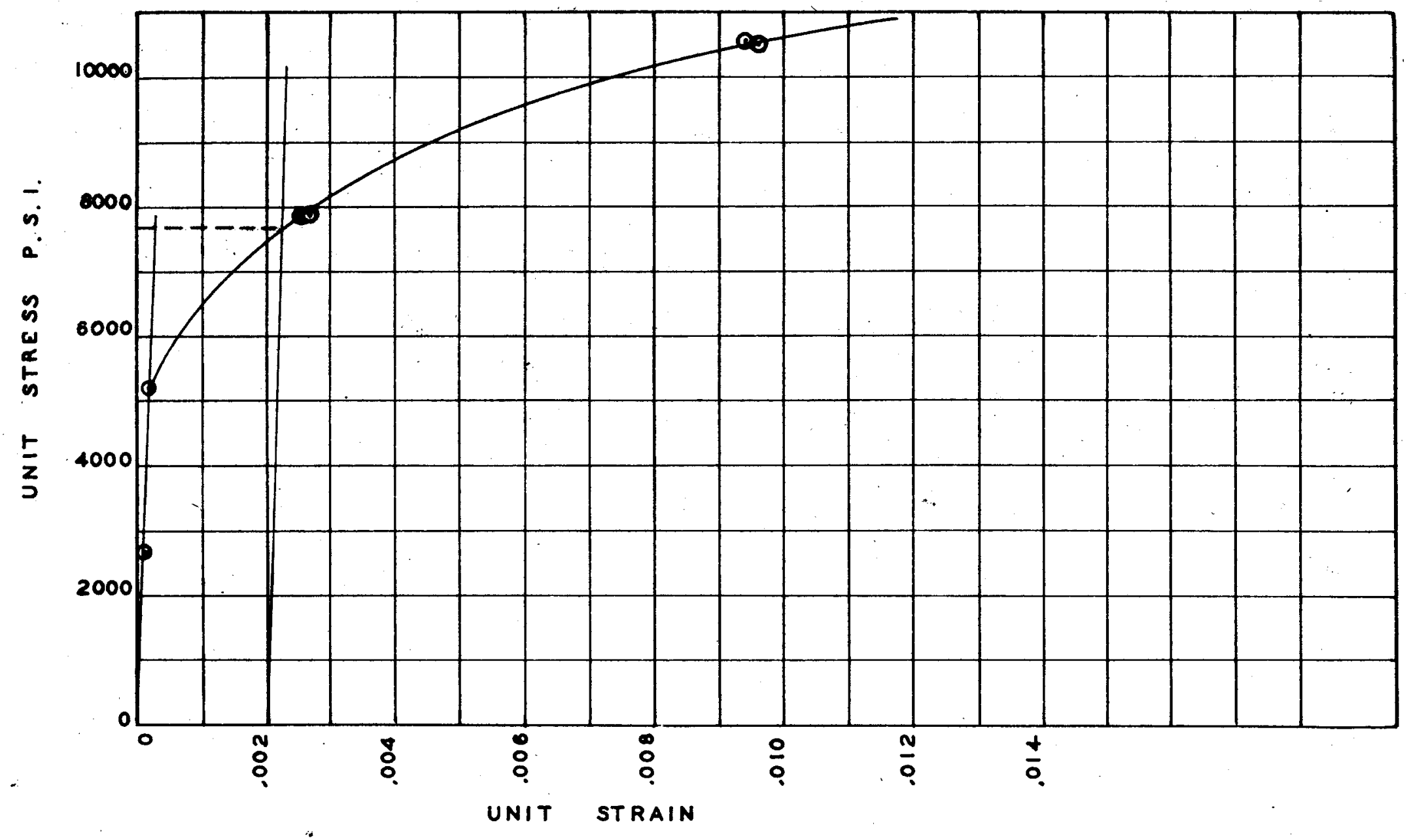

Figure 1. Stress-Strain Dlagran for 35-0 Aluminum Tubling 


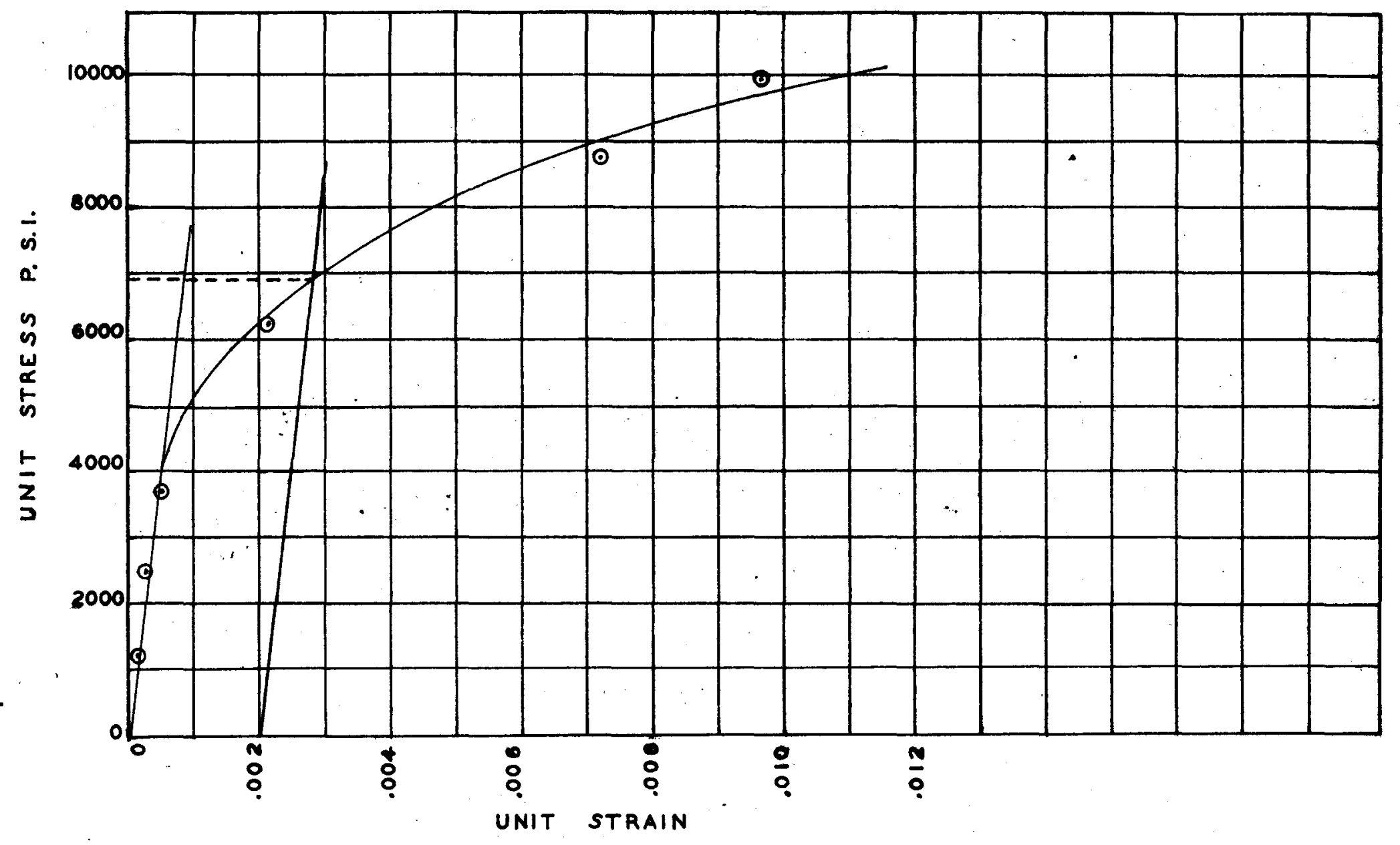

F1gure 2. Stress-Strain Diagram for B361-0 Aluminum Tubing. 


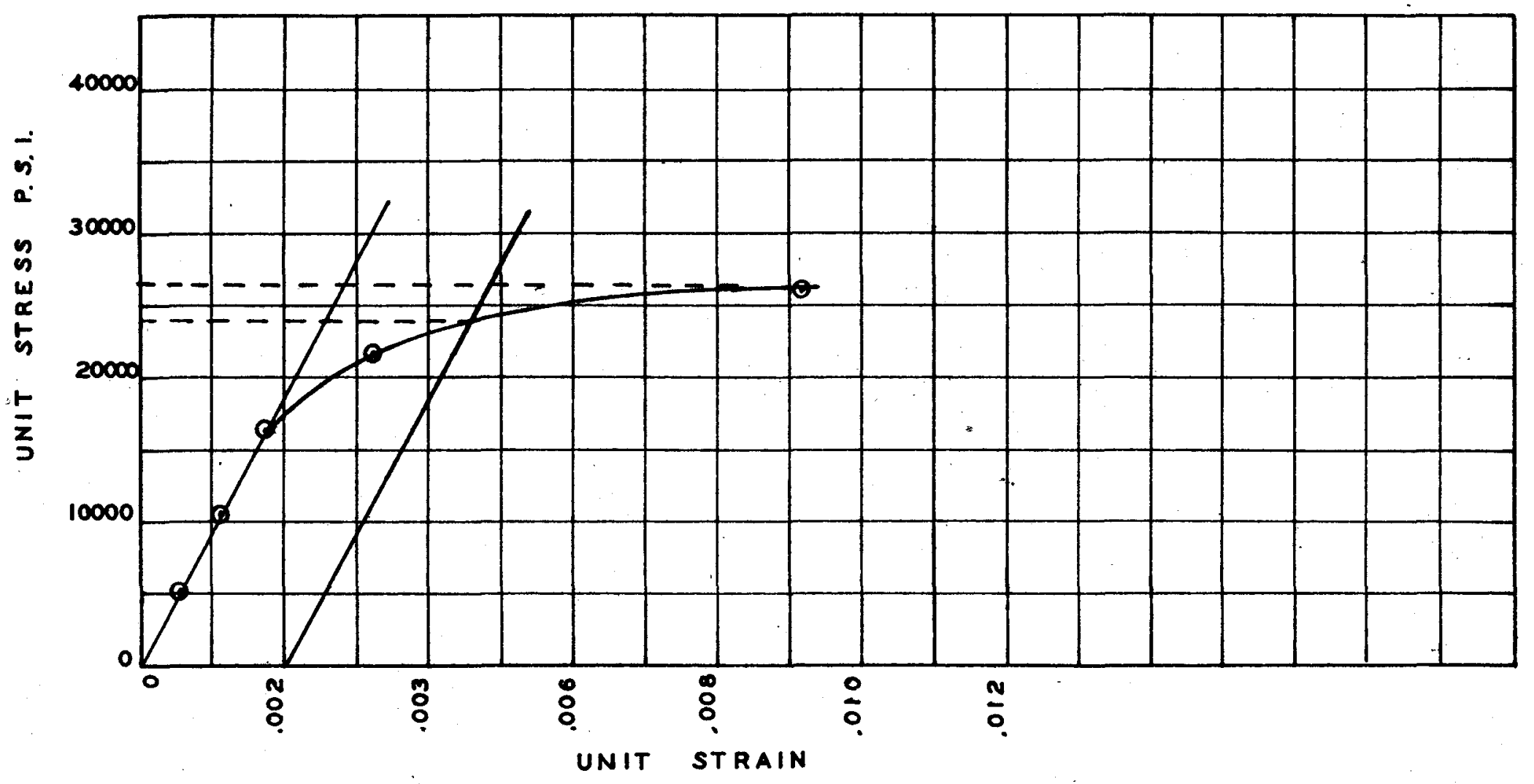

11gure 3. Stress-Straln Diagram for R561-T4 Aluminum Tubing 


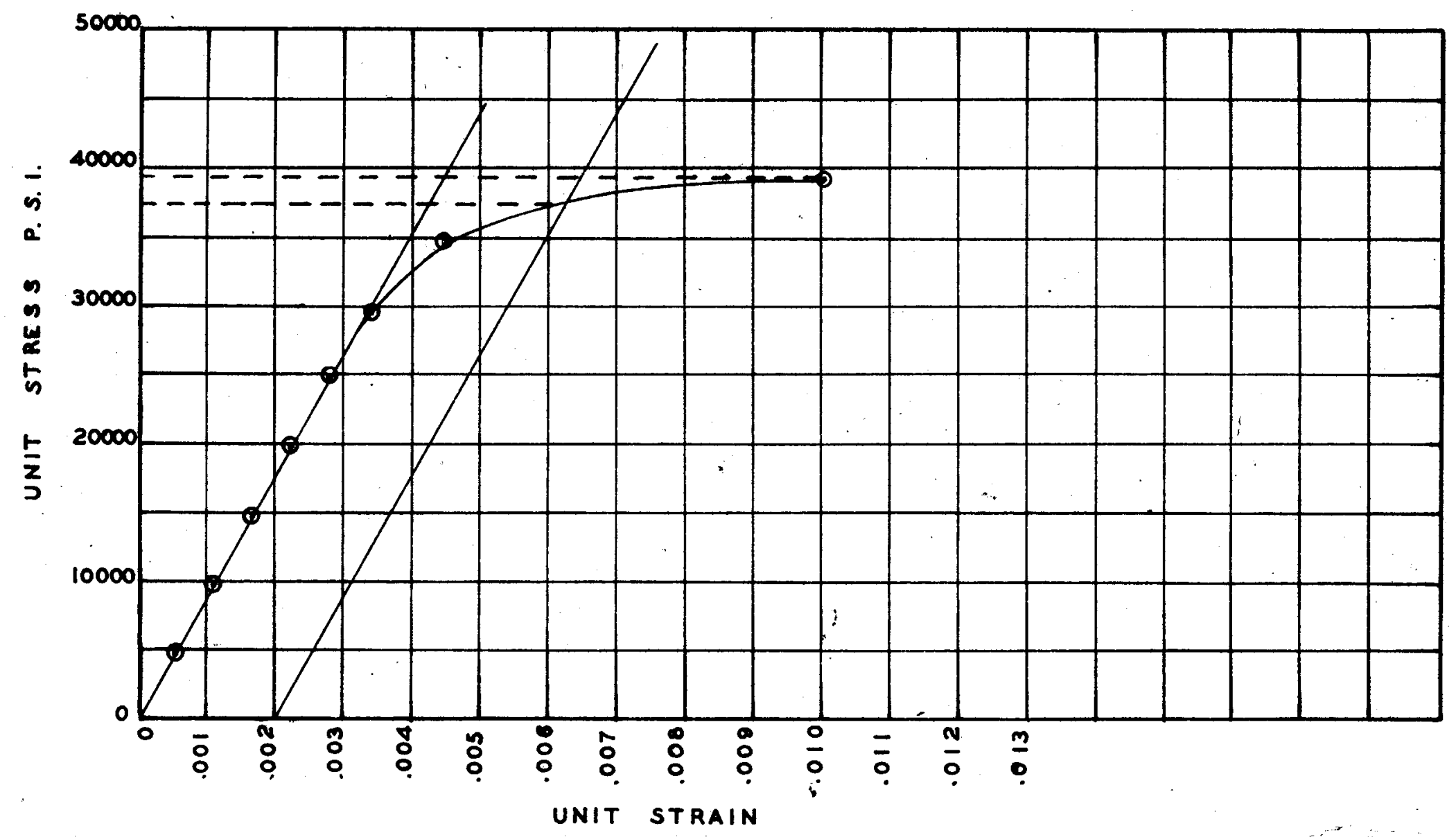

F1gure 4. Stress-Strain Dlagrem for R361-T6 Aluminum Tubing. 


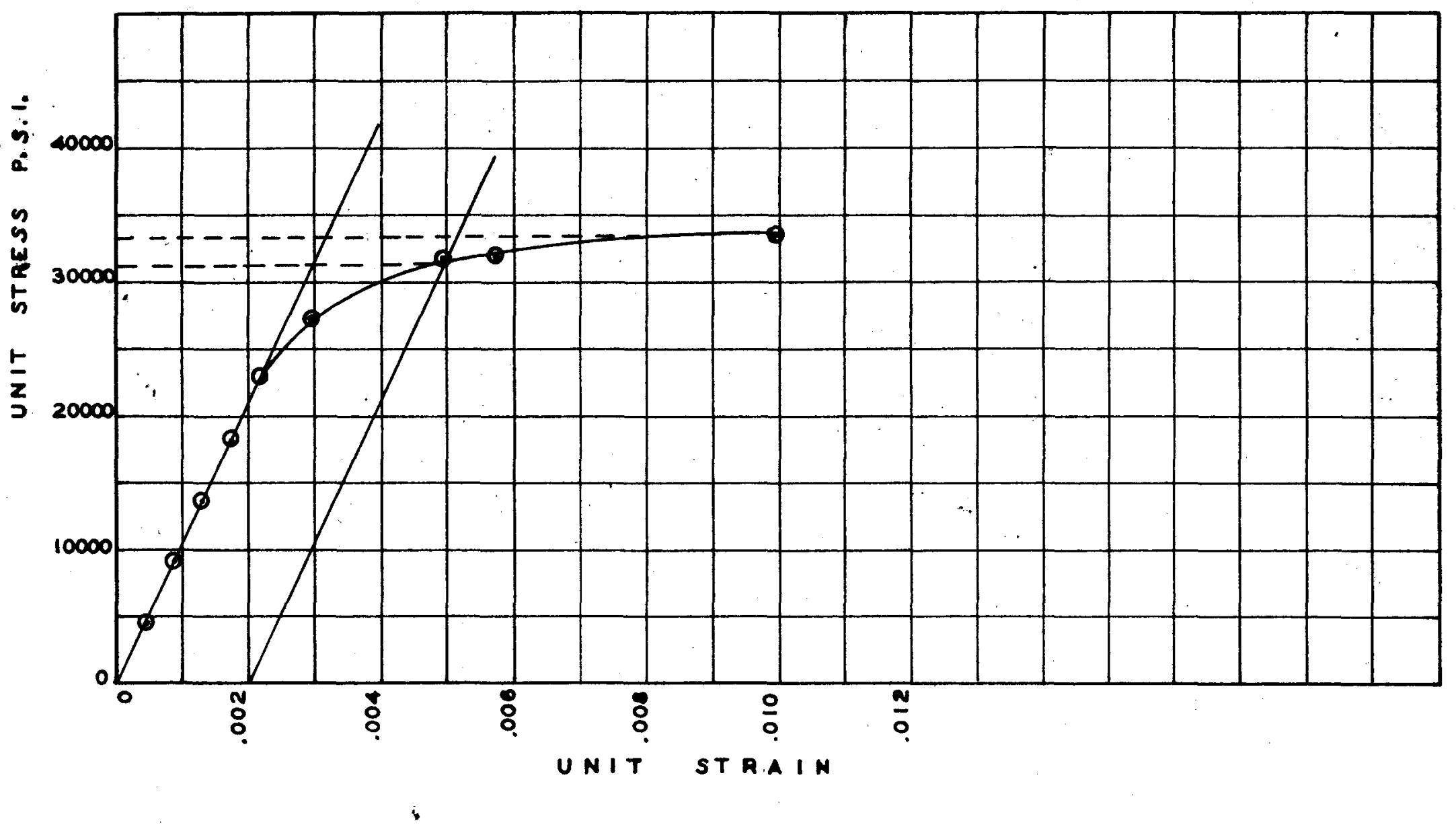

Figure 5. Stress-Strain Diagram for 63S-T Aluminum Tubing. 
TABLE II - MATERIAL AND SIZES OF COLUMNS TESTED

\begin{tabular}{|c|c|c|}
\hline ALLOY & SIZE & SHAPE \\
\hline $3 s-0$ & 0.065 in. $\times 1.00 \mathrm{in}$. & Tube \\
\hline $3 S-$ H14 & $0.061 \mathrm{ln} . \times 1.315 \mathrm{in}$. & $n$ \\
\hline $3 S-H 14$ & $0.125 \mathrm{in.} \times 1.5625 \mathrm{in}$. & * \\
\hline $\mathrm{R} 361-0$ & $0.194 \mathrm{in.} \times 1.58 \mathrm{in}$. & $"$ \\
\hline $\mathrm{RB} 61-0$ & 0.254 in. $x 1.75$ in. & $n$ \\
\hline R361 - T4 & 0.238 in. $\times 1.718 \mathrm{in}$. & $n$ \\
\hline $\mathrm{R3} 61$ - T4 & 0.064 in. $\times 1.00$ in. & " \\
\hline $\mathrm{R} 361-\mathrm{T} 6$ & $0.238 \mathrm{in.} \times 1.625 \mathrm{in}$. & " \\
\hline $63 S-T$ & 0.3125 in. $\times 2.875$ in. & " \\
\hline$P 361$ - $T$ & 0.437 in. $\times 6.00$ in. & Channel \\
\hline$R 361-T$ & $1-1 / 4$ in. $x 1-1 / 4$ in. $x 3 / 16$ in. & Angle \\
\hline $\mathrm{R} 361-\mathrm{T}$ & $2-1 / 2$ in. $x 2-1 / 2$ in. $x 1 / 4$ in. & n \\
\hline
\end{tabular}




$$
\begin{gathered}
\text { TABLE III - COLUMN DATA } \\
3 \text { S - } 0 \text { Tubing, } 0.065 \text { in. } \times 1.00 \mathrm{in} \text {. } \\
\text { Area }=0.19 \mathrm{Sq} \text {. Inches }
\end{gathered}
$$

\begin{tabular}{|c|c|c|c|c|c|}
\hline $\begin{array}{l}\text { End } \\
\text { Condition }\end{array}$ & Spec. No. & $\begin{array}{l}\text { Loading } \\
\text { Rate, Ib. } \\
\text { per min. }\end{array}$ & $\frac{L}{r}$ & $\begin{array}{c}\text { Unit Load } \\
\text { at Failure } \\
\text { pal }\end{array}$ & $\begin{array}{l}\text { Ave. } \\
\text { Unit Load psi }\end{array}$ \\
\hline Pinned & $\begin{array}{lll}1 & \text { PS } & 1 \\
1 & P S & 2 \\
1 & P S & 3\end{array}$ & 2000 & 174.5 & $\begin{array}{l}3,420 \\
3,170 \\
2,760\end{array}$ & 3115 \\
\hline$"$ & $\frac{1}{2} P I \frac{1}{6}$ & 2000 & 194 & $\begin{array}{l}2,100 \\
2,370\end{array}$ & 2235 \\
\hline " & $\begin{array}{lll}1 & \text { PSX } & 1 \\
1 & \text { PSX } & 2\end{array}$ & 2000 & 96.4 & $\begin{array}{l}3,950 \\
3,950\end{array}$ & 3950 \\
\hline $\begin{array}{l}n \\
n "\end{array}$ & $\begin{array}{lll}1 & P L & 1 \\
1 & P I & 2 \\
1 & P I & 3\end{array}$ & 2000 & 214 & $\begin{array}{l}1,710 \\
1,570 \\
1,570\end{array}$ & 1616 \\
\hline
\end{tabular}




$$
\begin{gathered}
\text { TABLE IV - COLUMN DATA } \\
3 \mathrm{~S}-\mathrm{H} 140.061 \mathrm{in} . \mathrm{x} 1.3125 \text { inches } \\
\text { Area }=0.241 \mathrm{sq} \text {. Inches }
\end{gathered}
$$

\begin{tabular}{|c|c|c|c|c|c|}
\hline $\begin{array}{l}\text { Ena } \\
\text { Cond1tion } \\
\end{array}$ & Speo. No. & $\begin{array}{l}\text { Loading } \\
\text { Rate, ib. } \\
\text { per min. }\end{array}$ & $\frac{L}{r}$ & $\begin{array}{l}\text { Unit Load } \\
\text { at Fallure } \\
\text { psi }\end{array}$ & $\begin{array}{l}\text { Ave } \\
\text { Unit Load psi }\end{array}$ \\
\hline Pinned & $\begin{array}{lll}3 & \operatorname{PSX} & 1 \\
3 & \operatorname{PSX} & 2\end{array}$ & 2000 & 54 & $\begin{array}{l}19,100 \\
19,400\end{array}$ & 19,250 \\
\hline $\begin{array}{l}n \\
n\end{array}$ & $\begin{array}{lll}3 & \text { PS } & 1 \\
3 & \text { PS } & 2 \\
3 & \text { PS } & 3\end{array}$ & 2000 & 97.5 & $\begin{array}{l}12,650 \\
13,300 \\
12,250\end{array}$ & 12,670 \\
\hline " & $\begin{array}{lll}3 & \text { PI } & 1 \\
3 & \text { PI } & 2 \\
3 & \text { PI } & 3\end{array}$ & 2000 & 108 & $\begin{array}{l}10,400 \\
10,600 \\
10,800\end{array}$ & 10,600 \\
\hline $\begin{array}{l}" \\
"\end{array}$ & $\begin{array}{lll}3 & \mathrm{PL} & 1 \\
3 & \mathrm{PI} & 2 \\
3 & \mathrm{PL} & 3\end{array}$ & 2000 & 118.5 & $\begin{array}{r}9,550 \\
10,200 \\
8,100\end{array}$ & 9,280 \\
\hline $\begin{array}{l}\text { One Fixed } \\
\text { and one } \\
\text { Pinned }\end{array}$ & $\begin{array}{lll}3 & \operatorname{osx} & 1 \\
3 & \operatorname{osx} & 2 \\
3 & \operatorname{osx} & 3\end{array}$ & ${ }^{2000} \frac{\mathrm{KI}}{r}=$ & $\begin{array}{l}76.8 \\
53.7\end{array}$ & $\begin{array}{l}18,25 \\
17,850 \\
19,100\end{array}$ & 18,400 \\
\hline $\begin{array}{l}n \\
n \\
" 1\end{array}$ & $\begin{array}{lll}3 & \text { OI } & 1 \\
3 & \text { OI } & 2 \\
3 & \text { OI } & 3\end{array}$ & ${ }^{2000} \frac{\mathrm{KL}}{2}=$ & $\begin{array}{l}162.5 \\
113.8\end{array}$ & $\begin{array}{r}9,990 \\
11,000 \\
10,800\end{array}$ & 10,580 \\
\hline $\begin{array}{l}\text { E1xed } \\
n \\
n\end{array}$ & $\begin{array}{lll}3 & F S X & 1 \\
3 & F S X & 2 \\
3 & F S X & 3\end{array}$ & $\frac{2000}{I}=$ & $\begin{array}{r}122 \\
61\end{array}$ & $\begin{array}{l}15,950 \\
16,800 \\
18,700\end{array}$ & 17,150 \\
\hline
\end{tabular}


TABLE V - COLUMN DATA

$$
35 \text { - } \mathrm{H} 140.125 \text { In. } x 1.5625 \text { Inohes }
$$

Area $=0.562 \mathrm{Sq}$. Inches

\begin{tabular}{|c|c|c|c|c|c|}
\hline $\begin{array}{l}\text { Ind } \\
\text { Cond1tion }\end{array}$ & Spea, No. & $\begin{array}{l}\text { Loading } \\
\text { Rate, ib. } \\
\text { per min. }\end{array}$ & $\frac{L}{5}$ & $\begin{array}{c}\text { Unit Load } \\
\text { at Fa1lure } \\
\text { psi }\end{array}$ & $\begin{array}{l}\text { Ave } \\
\text { Unit Load psi }\end{array}$ \\
\hline Pinned & $\begin{array}{l}\text { 4. PSX } 1 \\
4 \text { PSX } 2\end{array}$ & 2000 & 55 & $\begin{array}{l}18,600 \\
17,900\end{array}$ & 18,250 \\
\hline " & $\begin{array}{l}4 \text { PS } 1 \\
4 \text { PS } 2 \\
4 \text { PS } 3\end{array}$ & 2000 & 97 & $\begin{array}{l}10,650 \\
11,350 \\
10,625\end{array}$ & 10,875 \\
\hline $\begin{array}{l}n \\
n\end{array}$ & $\begin{array}{l}4 \text { PI } 1 \\
4 P I 2 \\
4 \text { PI } 3\end{array}$ & 2000 & 108 & $\begin{array}{l}9,800 \\
9,800 \\
9,950\end{array}$ & 9,815 \\
\hline "n & $\begin{array}{l}4 \mathrm{PL} \\
4 \mathrm{PI} \\
4 \mathrm{PL} \\
3\end{array}$ & 2000 & 118.5 & $\begin{array}{l}8,800 \\
8,850 \\
8,825\end{array}$ & 8,835 \\
\hline $\begin{array}{l}\text { One rixed } \\
\text { and one } \\
\text { Plnned }\end{array}$ & 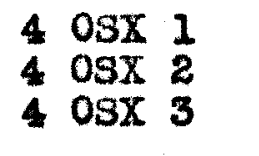 & ${ }^{2000} \frac{\mathrm{KI}}{\mathrm{F}}=$ & $\begin{array}{l}82.4 \\
57.6\end{array}$ & $\begin{array}{l}18,050 \\
18,900 \\
18,200\end{array}$ & 19,050 \\
\hline $\begin{array}{l}\text { Fixed } \\
n \\
n\end{array}$ & $\begin{array}{lll}4 & \text { FSX } & 1 \\
4 & \text { FSX } & 2 \\
4 & \text { FSX } & 3\end{array}$ & ${ }^{2000} \mathrm{KI}=$ & $\begin{array}{r}118 \\
59\end{array}$ & $\begin{array}{l}19,400 \\
19,800 \\
19,200\end{array}$ & 19,500 \\
\hline
\end{tabular}

No ult imate strength of material found. 
TABLE VI - COLUMN DATA

$$
\begin{gathered}
\text { R361 - } 00.124 \mathrm{In} \cdot x 1.58 \text { Inches } \\
\text { Area }=0,80 \mathrm{sq} \text {. Inches }
\end{gathered}
$$

\begin{tabular}{|c|c|c|c|c|c|}
\hline $\begin{array}{l}\text { Fnd } \\
\text { Cond1tion }\end{array}$ & Spec. No. & $\begin{array}{l}\text { Loading } \\
\text { Rate, Ib. } \\
\text { Der min. }\end{array}$ & $\frac{L}{L}$ & $\begin{array}{c}\text { Unit Load } \\
\text { at Fallure } \\
\text { pal }\end{array}$ & $\begin{array}{l}\text { Ave } \\
\text { Unit Load psi: }\end{array}$ \\
\hline$\underset{n}{\text { P1nned }}$ & $\begin{array}{lll}5 & \text { PSX } & 1 \\
5 & \text { PSX } & 2 \\
5 & \text { PSX } & 3\end{array}$ & 2000 & 92.5 & $\begin{array}{l}4000 \\
4940 \\
5000\end{array}$ & 4640 \\
\hline \multirow[t]{2}{*}{$\begin{array}{l}\text { One Fixed } \\
\text { and One } \\
\text { PInned }\end{array}$} & $\begin{array}{lll}5 & \text { OSX } & 1 \\
5 & \text { osX } & 2 \\
5 & \text { osX } & 3\end{array}$ & ${ }_{\frac{K I}{I}}^{2000}=$ & $\begin{array}{c}140.0 \\
98\end{array}$ & $\begin{array}{l}4500 \\
4440 \\
4130\end{array}$ & 4360 \\
\hline & \multicolumn{3}{|c|}{ Ultimate Strength } & 10000 & \\
\hline
\end{tabular}


TABLE VII - COLUMN DATA

$$
\begin{gathered}
\text { R361-0, } 0.254 \text { In. } x \text { I.75 In. } \\
\text { Area }=1.195 \mathrm{sq} . \text { In. }
\end{gathered}
$$

\begin{tabular}{|c|c|c|c|c|c|}
\hline $\begin{array}{l}\text { End } \\
\text { Cond1 ti on }\end{array}$ & Spec. Ho. & $\begin{array}{l}\text { Loading } \\
\text { Rate, Ib. } \\
\text { per min. }\end{array}$ & $\frac{L}{P}$ & $\begin{array}{l}\text { Unt Load } \\
\text { at Fallure } \\
\text { psi }\end{array}$ & $\begin{array}{r}\text { Ave. } \\
\text { Unt Load } \\
\end{array}$ \\
\hline PInned & $\begin{array}{lll}6 & \operatorname{PSX} & 1 \\
6 & \operatorname{PSX} & 2\end{array}$ & 2000 & 85.0 & $\begin{array}{l}4,700 \\
4,900\end{array}$ & 4,830 \\
\hline $\begin{array}{l}n \\
n \\
n\end{array}$ & $\begin{array}{lll}6 & \text { PS } & 1 \\
6 & \text { PS } & 2 \\
6 & \text { PS } & 3\end{array}$ & 2000 & 170.5 & $\begin{array}{l}2,300 \\
2,200 \\
2,560\end{array}$ & 2,350 \\
\hline $\begin{array}{l}n \\
n \\
n\end{array}$ & $\begin{array}{lll}6 & \text { PI } & 1 \\
6 & \text { PI } & 2 \\
6 & \text { PI } & 3\end{array}$ & 2000 & 190 & $\begin{array}{l}1,840 \\
2,210 \\
1,300\end{array}$ & 1,780 \\
\hline $\begin{array}{l}n \\
n \\
n\end{array}$ & $\begin{array}{lll}6 & P L & 1 \\
6 & P L & 2 \\
6 & P L & 3\end{array}$ & 2000 & 209 & $\begin{array}{l}1,840 \\
1,840 \\
1,760\end{array}$ & 1,810 \\
\hline
\end{tabular}


TABLE VIII - COLUMA DATA

$$
\mathrm{R361}-\mathrm{T4} 0.238 \mathrm{In} . \times 1.718 \mathrm{In} .
$$$$
\text { Area }=1.102 \mathrm{Sq} \cdot \mathrm{In} .
$$

\begin{tabular}{|c|c|c|c|c|c|}
\hline $\begin{array}{l}\text { Ind } \\
\text { Condition }\end{array}$ & Spec. No. & $\begin{array}{l}\text { Loading } \\
\text { Rate, ib. } \\
\text { Der min. }\end{array}$ & $\frac{I}{r}$ & $\begin{array}{c}\text { Unlt Load } \\
\text { at rallure } \\
\text { psi }\end{array}$ & Unit Loed est \\
\hline $\begin{array}{l}\text { Pinned } \\
n \\
n\end{array}$ & $\begin{array}{lll}8 & \text { PSX } & 1 \\
8 & \operatorname{PSX} & 2 \\
8 & \operatorname{PSX} & 3\end{array}$ & 2000 & 46.1 & $\begin{array}{l}22,800 \\
21,600 \\
22,000\end{array}$ & 22,300 \\
\hline$n$ & $\begin{array}{lll}8 & \text { PS } & 1 \\
8 & \text { PS } & 2 \\
8 & \text { PS } & 3\end{array}$ & 2000 & $103 \cdot 2$ & $\begin{array}{r}10,800 \\
9,650 \\
10,950\end{array}$ & 10,460 \\
\hline$n$ & $\begin{array}{lll}8 & P I & 1 \\
8 & P I & 2 \\
8 & P I & 3\end{array}$ & 2000 & 114.2 & $\begin{array}{l}8,900 \\
9,400 \\
8,600\end{array}$ & 8,960 \\
\hline$n$ & $\begin{array}{lll}8 & P L & 1 \\
8 & P L & 2 \\
8 & P L & 3\end{array}$ & 2000 & 126.1 & $\begin{array}{l}7.475 \\
7.210 \\
7.850\end{array}$ & 7,520 \\
\hline $\begin{array}{l}\text { One F1xed } \\
\text { and One } \\
\text { Plnned }\end{array}$ & $\begin{array}{lll}8 & \operatorname{csx} & 1 \\
8 & \operatorname{osX} & 2 \\
8 & \operatorname{csx} & 3\end{array}$ & ${ }_{\frac{\mathrm{KI}}{2}}^{2000}=$ & $\begin{array}{l}87.3 \\
61.1\end{array}$ & $\begin{array}{l}18,600 \\
18,300 \\
18,850\end{array}$ & 18,600 \\
\hline $\begin{array}{l}\text { E1xed } \\
n\end{array}$ & $\begin{array}{lll}8 & \operatorname{PSX} & 1 \\
8 & \operatorname{Fx} & 2 \\
8 & \operatorname{ISX} & 3\end{array}$ & ${ }_{\frac{\mathrm{KI}}{\mathrm{I}}}^{2000}=$ & $\begin{array}{r}124.5 \\
62.3\end{array}$ & $\begin{array}{l}17,300 \\
17,550 \\
16,900\end{array}$ & 17.250 \\
\hline $\begin{array}{l}n \\
n \\
n\end{array}$ & $\begin{array}{lll}8 & \text { OI } & 1 \\
8 & \text { OI } & 2 \\
8 & \text { OI } & 3\end{array}$ & ${ }^{2000} \frac{\mathrm{KI}}{\mathrm{I}}=$ & $\begin{array}{l}144.9 \\
101.5\end{array}$ & $\begin{array}{l}7,600 \\
6,030 \\
8,529\end{array}$ & 8,050 \\
\hline$n$ & $\begin{array}{lll}8 & \text { OL } & 1 \\
8 & \text { OL } & 2\end{array}$ & ${ }_{\frac{\mathrm{Xt}}{\mathrm{I}}}^{2000}=$ & $\begin{array}{l}180.3 \\
126\end{array}$ & $\begin{array}{l}6,805 \\
6,720\end{array}$ & 6,760 \\
\hline
\end{tabular}


TABLE IX - COLUMN DATA

R361 - T4 0.064 In. $x 1.00$ Inches

$$
\text { Area }=0.189 \mathrm{Sq} \cdot \text { In. }
$$

\begin{tabular}{|c|c|c|c|c|c|}
\hline $\begin{array}{l}\text { End } \\
\text { Cond1tion }\end{array}$ & Spoc. No. & $\begin{array}{l}\text { Loading } \\
\text { Rate, Ib. } \\
\text { per min. }\end{array}$ & $\frac{I}{5}$ & $\begin{array}{l}\text { Unit Losd } \\
\text { at Fal lure } \\
\text { pal }\end{array}$ & $\begin{array}{l}\text { Ave. } \\
\text { Unte Load } \\
\end{array}$ \\
\hline Fixed & $\begin{array}{lll}7 & F S & 1 \\
7 & F S & 2 \\
7 & F S & 3\end{array}$ & ${ }^{2000} \frac{\mathrm{KI}}{\mathrm{r}}=$ & $\begin{array}{c}186 \\
93.2\end{array}$ & $\begin{array}{r}10,600 \\
13,200 \\
9,800\end{array}$ & 11,200 \\
\hline & Ul tima te & trongth & & 26,500 & \\
\hline
\end{tabular}


TABLE X - COLUMN DATA

$$
\begin{gathered}
\text { R361 - } T 6=0.238 \text { In. } x \text { I.625 In. } \\
\text { Area }=1.205 \mathrm{sq} \text {. Inches }
\end{gathered}
$$

\begin{tabular}{|c|c|c|c|c|c|}
\hline $\begin{array}{l}\text { End } \\
\text { Condition }\end{array}$ & Spec. No. & $\begin{array}{l}\text { Loading } \\
\text { Rate, ib. } \\
\text { per min. }\end{array}$ & $\frac{L}{r}$ & $\begin{array}{l}\text { Uast Load } \\
\text { at Failure } \\
\text { pol }\end{array}$ & $\begin{array}{l}\text { Avo. } \\
\text { Unit Load ps1 }\end{array}$ \\
\hline $\begin{array}{l}\text { Pinned } \\
n\end{array}$ & $\begin{array}{lll}9 & P S & 1 \\
9 & P S & 2 \\
9 & \text { PS } & 3\end{array}$ & 2000 & 73.2 & $\begin{array}{l}24,600 \\
23,950 \\
23,700\end{array}$ & 24,080 \\
\hline n & $\begin{array}{lll}9 & P I & 1 \\
9 & P I & 2 \\
9 & P I & 3\end{array}$ & 2000 & 81.2 & $\begin{array}{l}21,200 \\
21,200 \\
22,400\end{array}$ & 21,600 \\
\hline $\begin{array}{l}n \\
n \\
n\end{array}$ & $\begin{array}{lll}9 & P L & 1 \\
9 & P L & 2 \\
9 & P L & 3\end{array}$ & 2000 & 89.5 & $\begin{array}{l}17,100 \\
16,700 \\
15,800\end{array}$ & 16,530 \\
\hline $\begin{array}{l}\text { One Fixed } \\
\text { and one } \\
\text { Pinned }\end{array}$ & $\begin{array}{lll}9 & \operatorname{OsX} & 1 \\
9 & \operatorname{csx} & 2 \\
9 & \operatorname{osx} & 3\end{array}$ & ${ }^{2000} \frac{\mathrm{KL}}{\mathrm{r}}=$ & $\begin{array}{l}65.2 \\
45.6\end{array}$ & $\begin{array}{l}31,500 \\
31,700 \\
31,400\end{array}$ & 31,510 \\
\hline $\begin{array}{l}\text { F1xed } \\
n\end{array}$ & $\begin{array}{lll}9 & F S X & 1 \\
9 & F S X & 2 \\
9 & F S X & 3\end{array}$ & ${ }^{2000} \frac{\mathrm{KI}}{r}=$ & $\begin{array}{l}93.2 \\
46.5\end{array}$ & $\begin{array}{l}30,900 \\
30,000 \\
29,000\end{array}$ & 29,970 \\
\hline $\begin{array}{l}n \\
n \\
n\end{array}$ & $\begin{array}{lll}9 & F S & 1 \\
9 & F S & 2 \\
9 & F S & 3\end{array}$ & ${ }^{2000} \frac{\mathrm{KI}}{r}=$ & $\begin{array}{l}156 \\
78.1\end{array}$ & $\begin{array}{l}13,850 \\
13,550 \\
13,550\end{array}$ & 13,650 \\
\hline $\begin{array}{l}n \\
n \\
u\end{array}$ & $\begin{array}{lll}9 & \text { FI } & 1 \\
9 & \text { FI } & 2 \\
9 & \text { FI } & 3\end{array}$ & ${ }^{2000} \frac{\mathrm{KL}}{r}=$ & $\begin{array}{r}174.5 \\
87.2\end{array}$ & $\begin{array}{l}10,450 \\
10,300 \\
10,700\end{array}$ & 14,480 \\
\hline n & 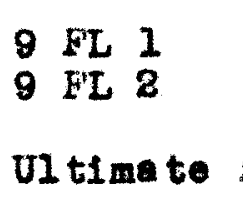 & $\underbrace{2000}_{\text {reng th }} \frac{\mathrm{KL}}{r}=$ & $\begin{array}{r}191.5 \\
95.8\end{array}$ & $\begin{array}{r}8,630 \\
8,840 \\
39,500\end{array}$ & 8,720 \\
\hline
\end{tabular}


TABLE XI - COLUAN DATA

$$
\begin{gathered}
63 \mathrm{~S}-\mathrm{T} 0.3125 \text { In. } x 1.875 \text { Inchea } \\
\text { Area }=1.542 \mathrm{sq} \text {. Inches }
\end{gathered}
$$

\begin{tabular}{|c|c|c|c|c|c|}
\hline $\begin{array}{l}\text { End } \\
\text { Condition }\end{array}$ & Spec. Ho. & $\begin{array}{l}\text { Loading } \\
\text { late, ib. } \\
\text { per min. }\end{array}$ & $\frac{L}{I}$ & $\begin{array}{l}\text { Unit Load } \\
\text { t Fallure } \\
\text { psi }\end{array}$ & Untt Loed psi \\
\hline $\begin{array}{l}\text { Planed } \\
n \\
n\end{array}$ & $\begin{array}{lll}11 & \mathrm{PSX} & 1 \\
11 & \mathrm{PSX} & 2 \\
11 & \mathrm{PSX} & 3\end{array}$ & 2000 & 55 & $\begin{array}{l}26,000 \\
25,600 \\
27,200\end{array}$ & 26,260 \\
\hline $\begin{array}{l}n \\
n\end{array}$ & $\begin{array}{lll}11 & P S & 1 \\
11 & S S & 2 \\
11 & \text { PS } & 3\end{array}$ & 2000 & 96.5 & $\begin{array}{l}13,350 \\
14,550 \\
14,050\end{array}$ & 13,980 \\
\hline $\begin{array}{l}n \\
n\end{array}$ & $\begin{array}{lll}11 & \text { PI } & 1 \\
11 & \text { PI } & 2 \\
11 & \text { PI } & 3\end{array}$ & 2000 & 107 & $\begin{array}{l}12,600 \\
12,750 \\
12,000\end{array}$ & 12,450 \\
\hline " & $\begin{array}{lll}11 & \text { PL } & 1 \\
11 & \text { PL } & 2 \\
11 & \text { PL } & 3\end{array}$ & 2000 & 117.5 & $\begin{array}{r}9,140 \\
10,600 \\
9,260\end{array}$ & 9,700 \\
\hline $\begin{array}{l}\text { One Flxed } \\
\text { and one } \\
\text { Pinned }\end{array}$ & $\begin{array}{lll}11 & \operatorname{osx} & 1 \\
11 & \operatorname{osx} & 2 \\
11 & \operatorname{osx} & 3\end{array}$ & ${ }^{2000} \frac{\mathrm{KI}}{r}=$ & $\begin{array}{l}80.2 \\
56.2\end{array}$ & $\begin{array}{l}24,400 \\
24,600 \\
25,000\end{array}$ & 24,700 \\
\hline Flxed & $\begin{array}{lll}11 & \text { FSX } & 1 \\
11 & \text { FSX } 2 \\
\text { v1 tima te }\end{array}$ & $\frac{\mathrm{XI}}{\mathrm{r}}=$ & $\begin{array}{r}120 \\
60\end{array}$ & $\begin{array}{l}23,100 \\
22,450 \\
33,500\end{array}$ & 22,770 \\
\hline
\end{tabular}


TABLE XII - COLUMN DATH

R361 - T 6 In. $\times 0.437$ In. Channel

Area $=3.82$ Square In.

\begin{tabular}{|c|c|c|c|c|c|}
\hline $\begin{array}{l}\text { End } \\
\text { Condition }\end{array}$ & spec. Ho. & $\begin{array}{l}\text { Looding } \\
\text { Rate, Ib. } \\
\text { por min. }\end{array}$ & $\frac{L}{r}$ & $\begin{array}{l}\text { Unft Load } \\
\text { at Failure } \\
\text { po1 }\end{array}$ & $\begin{array}{l}\text { Ave. } \\
\text { Unit Load psi }\end{array}$ \\
\hline Pinned & $\begin{array}{lll}12 & \text { PS } & 1 \\
12 & \text { PS } & 2\end{array}$ & 8000 & 34.2 & $\begin{array}{l}27,200 \\
34,800\end{array}$ & 31,000 \\
\hline $\begin{array}{l}n \\
" 1\end{array}$ & $\begin{array}{lll}12 & \text { PI } & 1 \\
12 & \text { PI } & 2 \\
12 & \text { PI } & 3\end{array}$ & 8000 & 80.8 & $\begin{array}{l}20,900 \\
20,000 \\
19,100\end{array}$ & 19,700 \\
\hline $\begin{array}{l}n \\
n \\
n\end{array}$ & $\begin{array}{lll}12 & P L & 1 \\
12 & P L & 2 \\
12 & P L & 3\end{array}$ & 8000 & 89.4 & $\begin{array}{l}16,500 \\
17,400 \\
19,200\end{array}$ & 17,700 \\
\hline $\begin{array}{l}\text { One fixed } \\
\text { and One } \\
\text { Pinned }\end{array}$ & $\begin{array}{lll}12 & \text { OS } 1 \\
12 & \text { OS } 2\end{array}$ & ${ }^{8000} \frac{\text { KL }}{r}=$ & $\begin{array}{l}57.7 \\
40.4\end{array}$ & $\begin{array}{l}31,400 \\
34,000\end{array}$ & 32,100 \\
\hline n & $\begin{array}{lll}12 & \text { OI } & 1 \\
12 & \text { OI } & 2 \\
12 & \text { OI } & 3\end{array}$ & ${ }^{8000} \frac{K L}{r}=$ & $\begin{array}{r}215.5 \\
80.8\end{array}$ & $\begin{array}{l}24,400 \\
24,200 \\
21,000\end{array}$ & 23,200 \\
\hline Fixed & $\begin{array}{lll}12 & \text { FS } & 1 \\
12 & \text { FS } & 2 \\
12 & \text { FS } 3\end{array}$ & $\frac{{ }^{8 L}}{r}=$ & $\begin{array}{l}92.8 \\
46.4\end{array}$ & $\begin{array}{l}32,100 \\
32,600 \\
34,400\end{array}$ & 33,000 \\
\hline$"$ & $\begin{array}{lll}12 & \text { FI } & 1 \\
12 & \text { FI } & 2\end{array}$ & $\frac{8000}{r}=$ & $\begin{array}{r}174 \\
87.1\end{array}$ & $\begin{array}{l}12,650 \\
12,300\end{array}$ & 12,480 \\
\hline
\end{tabular}


TABLE XIII - COLUMN DATA

R361-T $1 \frac{1}{6}$ In. $\times 1 \frac{1}{6}$ In. $\times 3 / 16$ In. Angle

Aree $=0.43 \mathrm{sq}$. Inches

\begin{tabular}{|c|c|c|c|c|c|c|}
\hline $\begin{array}{l}\text { End } \\
\text { Cond1 tion }\end{array}$ & spec. & Ho. & $\begin{array}{l}\text { Loading } \\
\text { Ra te, ib. } \\
\text { per min. }\end{array}$ & $\frac{L}{r}$ & $\begin{array}{l}\text { Unt Load } \\
\text { at Fa1lure } \\
\text { psi }\end{array}$ & $\begin{array}{l}\text { Ave. } \\
\text { Un1t Load pal }\end{array}$ \\
\hline $\begin{array}{l}\text { Pinned } \\
\text { Ends }\end{array}$ & $\begin{array}{ll}13 & P S \\
13 & P S \\
13 & P S\end{array}$ & $\begin{array}{l}1 \\
2 \\
3\end{array}$ & 2000 & 40.6 & $\begin{array}{l}31,200 \\
30,400 \\
30,500\end{array}$ & 30,700 \\
\hline $\begin{array}{l}n \\
n \\
n\end{array}$ & $\begin{array}{ll}13 & \mathrm{PI} \\
13 & \mathrm{PI} \\
13 & \mathrm{PI}\end{array}$ & $\frac{1}{2}$ & 2000 & 81.2 & $\begin{array}{l}17,850 \\
16,250 \\
16,220\end{array}$ & 16,770 \\
\hline $\begin{array}{l}n \\
n \\
n\end{array}$ & $\begin{array}{ll}13 & \mathrm{PL} \\
13 & \mathrm{PL} \\
13 & \mathrm{PL}\end{array}$ & $\begin{array}{l}1 \\
2 \\
3\end{array}$ & 2000 & 89.5 & $\begin{array}{l}15,100 \\
16,750 \\
16,700\end{array}$ & 16,180 \\
\hline $\begin{array}{l}\text { One } 1 \text { xed } \\
\text { and One } \\
\text { Plnned }\end{array}$ & $\begin{array}{ll}13 & 0 \$ \\
13 & 0 \$ \\
13 & 08\end{array}$ & $\begin{array}{l}1 \\
2 \\
3\end{array}$ & ${ }^{2000} \frac{\mathrm{KI}}{x}=$ & $\begin{array}{l}52 \\
36.4\end{array}$ & $\begin{array}{l}28,100 \\
28,600 \\
29,200\end{array}$ & 28,600 \\
\hline
\end{tabular}


TABLE XIV - COLUMN DATA

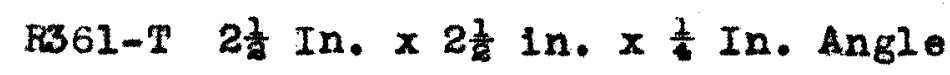

Area $=1.19 \mathrm{Sq}$. Inches

\begin{tabular}{|c|c|c|c|c|c|}
\hline $\begin{array}{l}\text { End } \\
\text { Condi ti on }\end{array}$ & Spec. No. & $\begin{array}{l}\text { Loading } \\
\text { Ra te, Ib. } \\
\text { per min. }\end{array}$ & $\frac{L}{r}$ & $\begin{array}{l}\text { Unit Load } \\
\text { at Failure } \\
\text { pai }\end{array}$ & $\begin{array}{l}\text { Ave. } \\
\text { Unit Losd PsI }\end{array}$ \\
\hline $\begin{array}{l}\text { PInned } \\
n\end{array}$ & $\begin{array}{lll}14 & \text { PS } & 1 \\
14 & \text { PS } & 2 \\
14 & \text { PS } & 3\end{array}$ & 2000 & 57.5 & $\begin{array}{r}26,300 \\
31,500 \\
28,850\end{array}$ & 28,880 \\
\hline " & $\begin{array}{lll}14 & \text { PI } & 1 \\
14 & \text { PI } & 2 \\
14 & \text { PI } & 3\end{array}$ & 2000 & 81.2 & $\begin{array}{l}21,000 \\
17,700 \\
16,100\end{array}$ & 18,260 \\
\hline 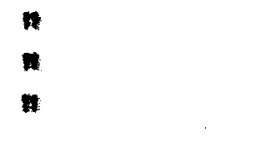 & $\begin{array}{lll}14 & \text { PSX } & 1 \\
14 & \text { PSX } & 2 \\
14 & \text { PSX } & 3\end{array}$ & 2000 & 40.4 & $\begin{array}{l}32,200 \\
33,600 \\
31,800\end{array}$ & 32,530 \\
\hline $\begin{array}{l}\text { One Fixed } \\
\text { and One } \\
\text { Pinned }\end{array}$ & $\begin{array}{lll}14 & \text { OSX } & 1 \\
14 & \text { OSX } & 2 \\
14 & \text { osX } & 3\end{array}$ & $\frac{\mathrm{KI}}{r}=$ & $\begin{array}{l}58.7 \\
41.1\end{array}$ & $\begin{array}{l}29,100 \\
27,700 \\
27,400\end{array}$ & 28,070 \\
\hline$n$ & $\begin{array}{lll}14 & \text { OI } & 1 \\
14 & \text { OI } & 2 \\
14 & \text { OI } & 3\end{array}$ & $2000 \frac{K L}{r}=$ & $\begin{array}{r}122.5 \\
85.6\end{array}$ & $\begin{array}{l}15,750 \\
15,800 \\
14,400\end{array}$ & 15,320 \\
\hline Fixed & $\begin{array}{lll}14 & \text { FSX } & 1 \\
14 & \text { FSX } & 2 \\
14 & F S X & 3\end{array}$ & $\frac{2000}{r}=$ & $\begin{array}{l}93.8 \\
46.8\end{array}$ & $\begin{array}{l}28,850 \\
28,900 \\
27,100\end{array}$ & 28,280 \\
\hline " & $\begin{array}{lll}14 & \text { FS } & 1 \\
14 & \text { FS } & 2 \\
14 & \text { FS } & 3\end{array}$ & ${ }^{2000} \frac{\mathrm{KI}}{r}=$ & $\begin{array}{r}158 \\
79\end{array}$ & $\begin{array}{l}14,800 \\
14,800 \\
14,850\end{array}$ & 14,820 \\
\hline " & $\begin{array}{lll}14 & \text { FI } & 1 \\
14 & F I & 2 \\
14 & F I & 3\end{array}$ & $\frac{2000}{K L}=$ & $\begin{array}{r}174.5 \\
87.2\end{array}$ & $\begin{array}{l}12,450 \\
13,200 \\
13,000\end{array}$ & 12,880 \\
\hline$"$ & $\begin{array}{lll}14 & \text { FL } & 1 \\
14 & \text { FL } 2\end{array}$ & ${ }_{\frac{K L}{r}}^{2000}=$ & $\begin{array}{r}190 \\
95\end{array}$ & $\begin{array}{l}10,600 \\
10,100\end{array}$ & 10,250 \\
\hline
\end{tabular}




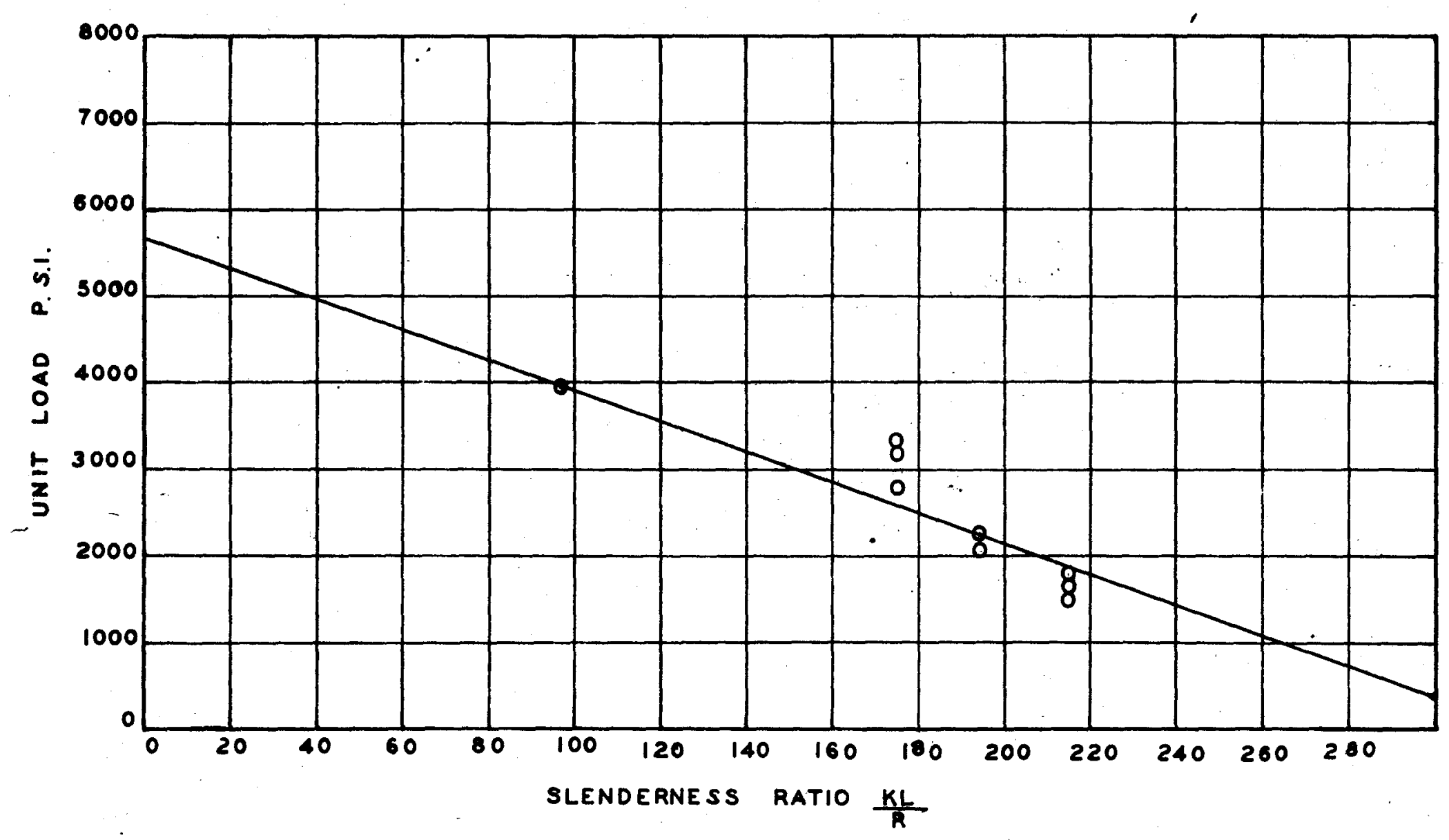

I1gure 6. Unit Load Vs. Slenderness Rat1o for 3S-0 Tubing Columns, $0.065^{\prime \prime} \times 2.00^{\prime \prime} ; K=1,0.7,0.5$

o Pinned Fnds. 


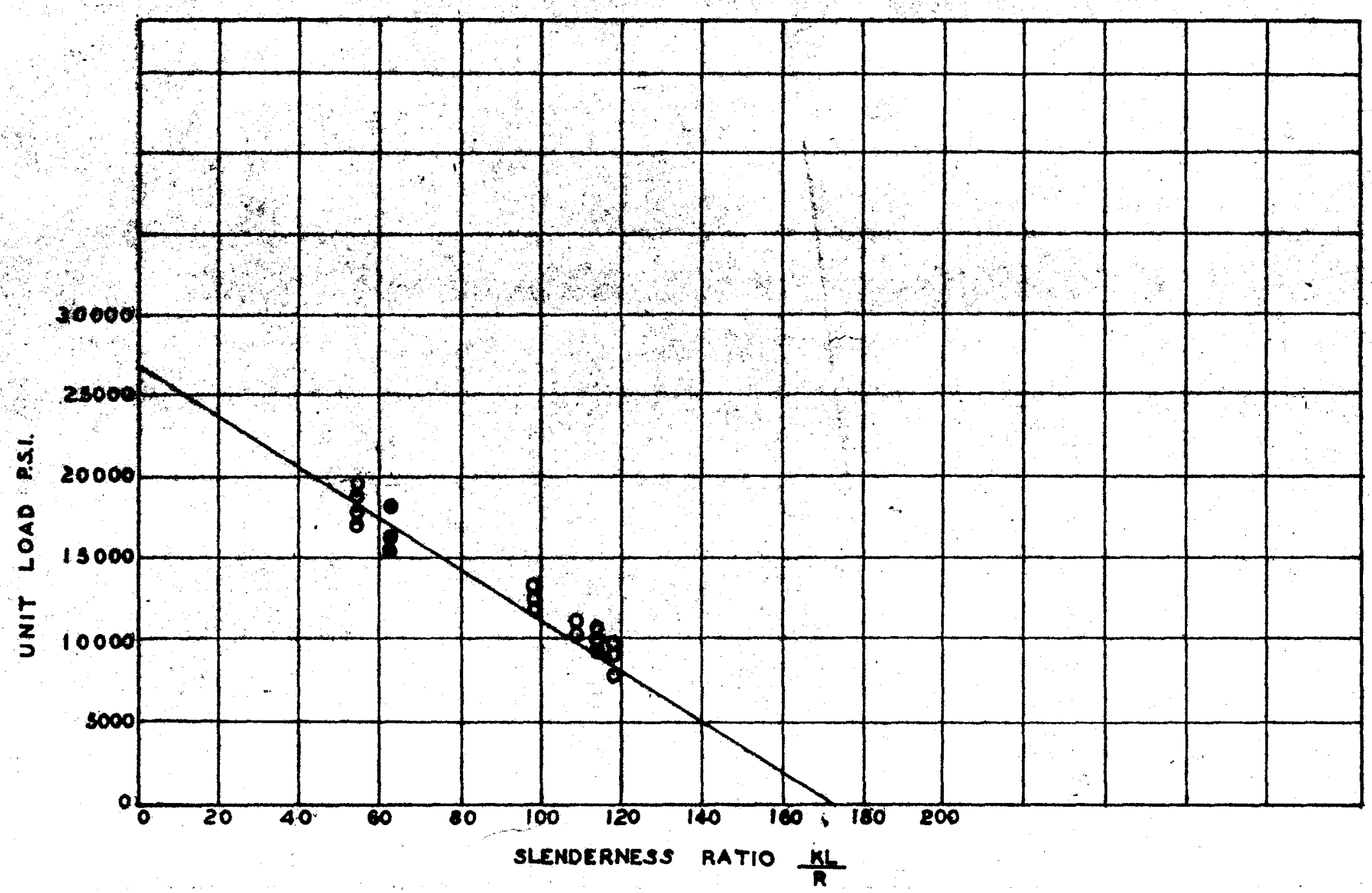

F1gure 7. Un1t Load ra, Slenderness Ratlo for 35-H14 Tublng Columns, $0.061^{*} \times 2.3125^{n} ; \mathrm{K}=1,0.7,0.5$

- PInned Fnds, O One Plinned and One Fixed, - Fixed Bnds. 


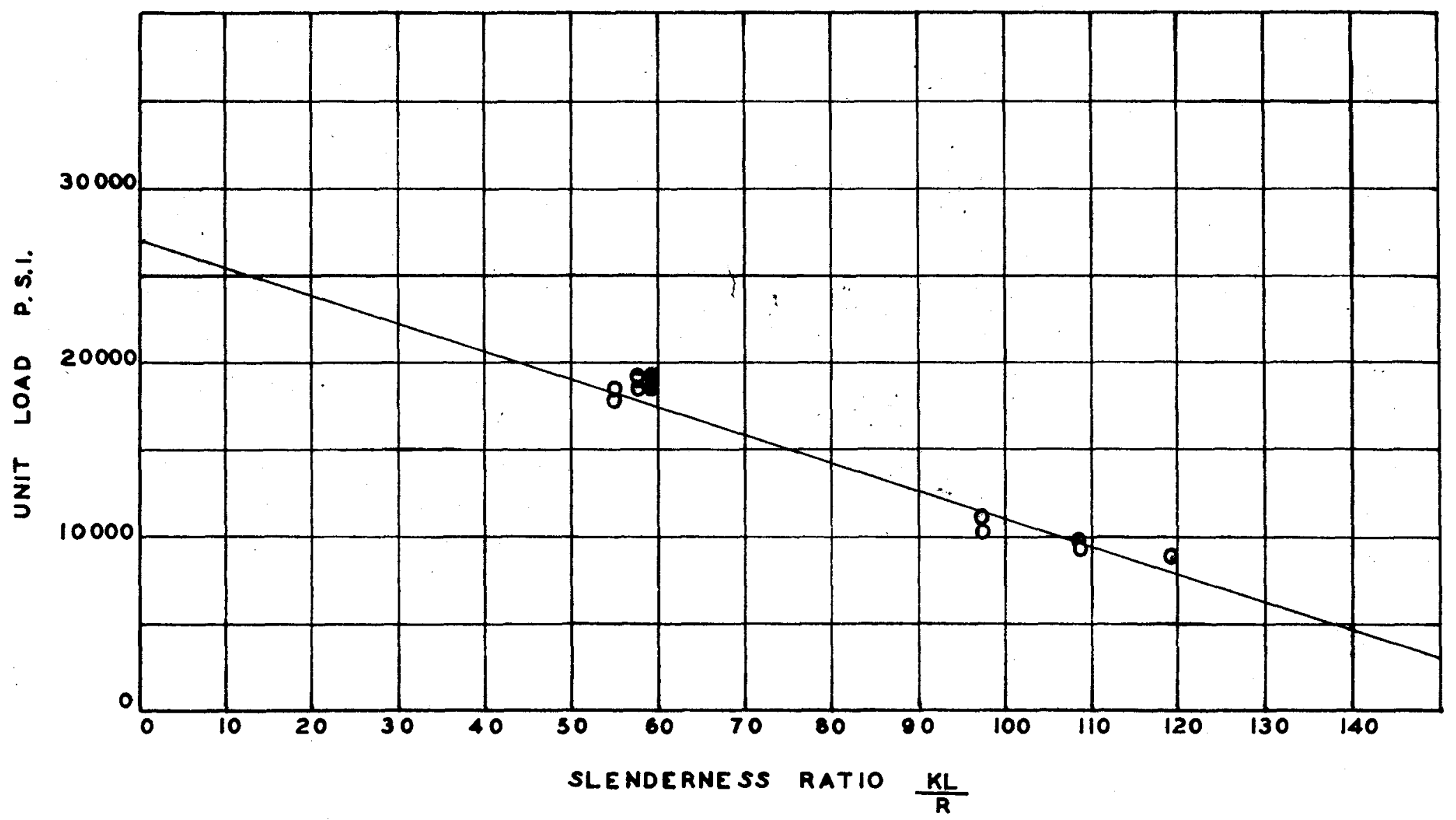

Figure 6. Unit Load rs. Slenderness Ratlo for 3S-H14 Tubing Colunns, $0.125^{n}$ x $2.5625^{n} ; \mathrm{K}=1,0.7,0.5$

- PInned Finds, 0 One PInned One Plxed End, - Flxed Enda. 


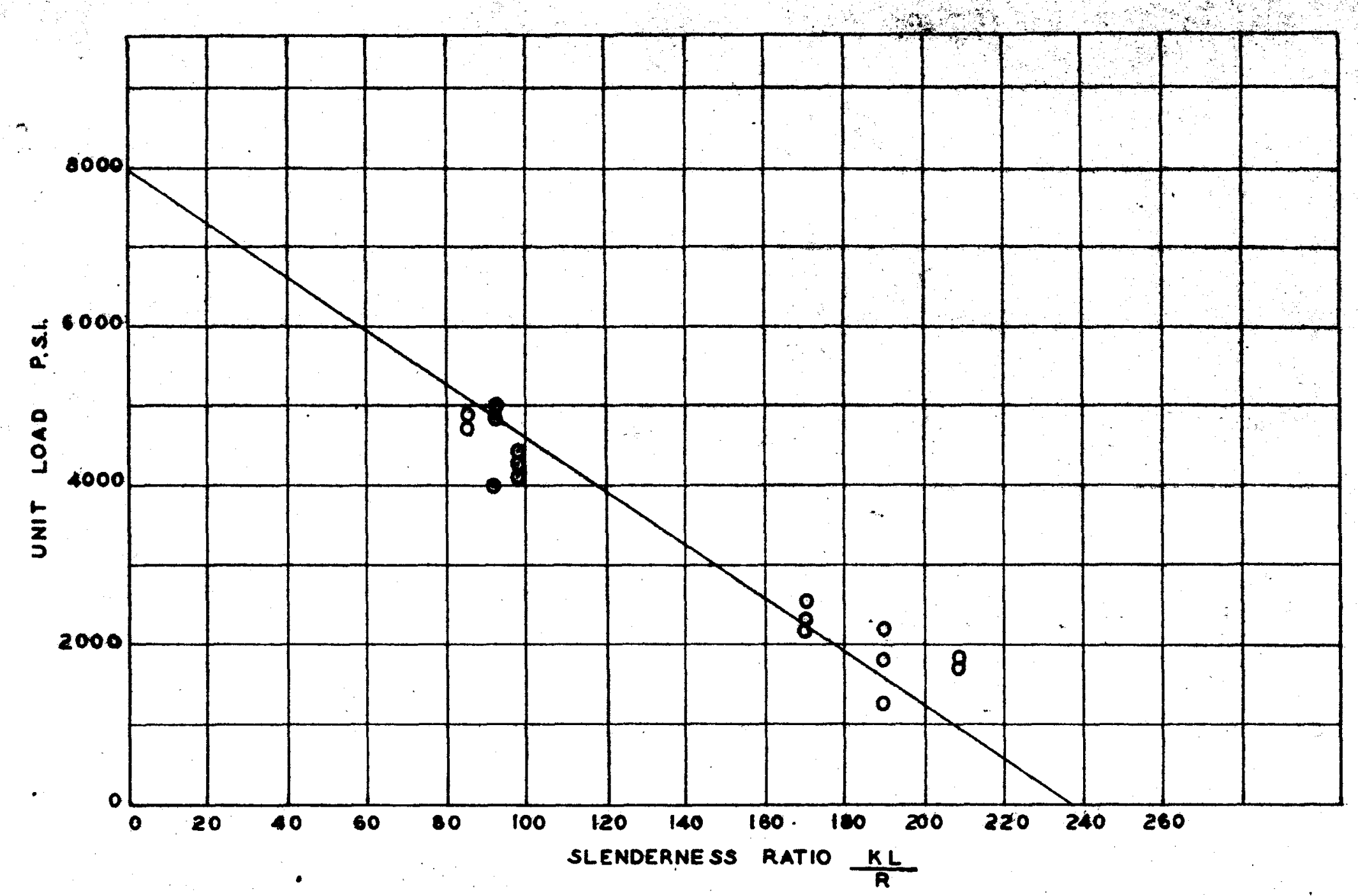

Figure 9. Unit Load rs. Slenderness Ratio for R361-0 Rubing Colume, $0.254^{\prime \prime} \times 1.75^{\prime \prime} ; \mathrm{K}=1,0.7,0.5$.

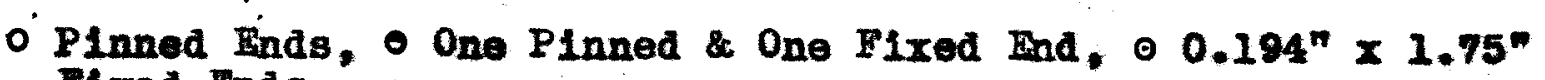
Fixed Ends. 


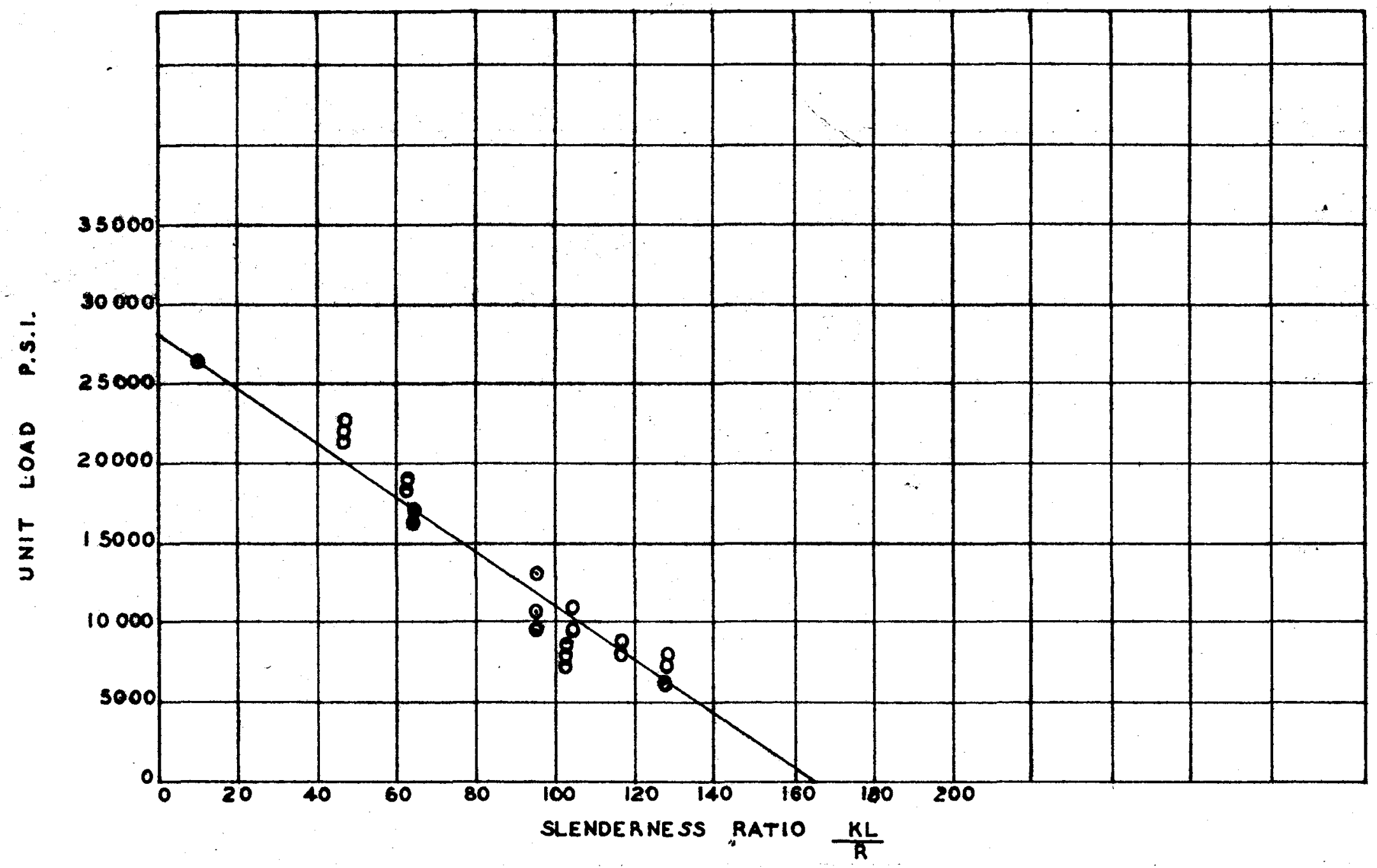
Figure 10. Unit Load $V_{S}$ Slenderness Ratio for R361-T4 Tubing Columns,
$0.238^{n} \times 1.718^{n}: K=1,0.7,0.5$.

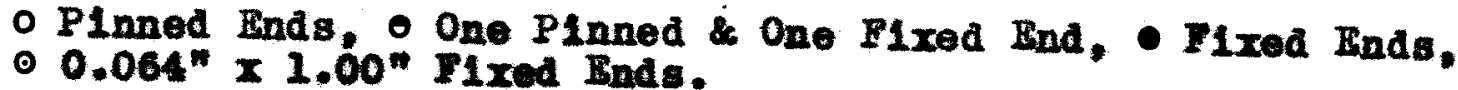




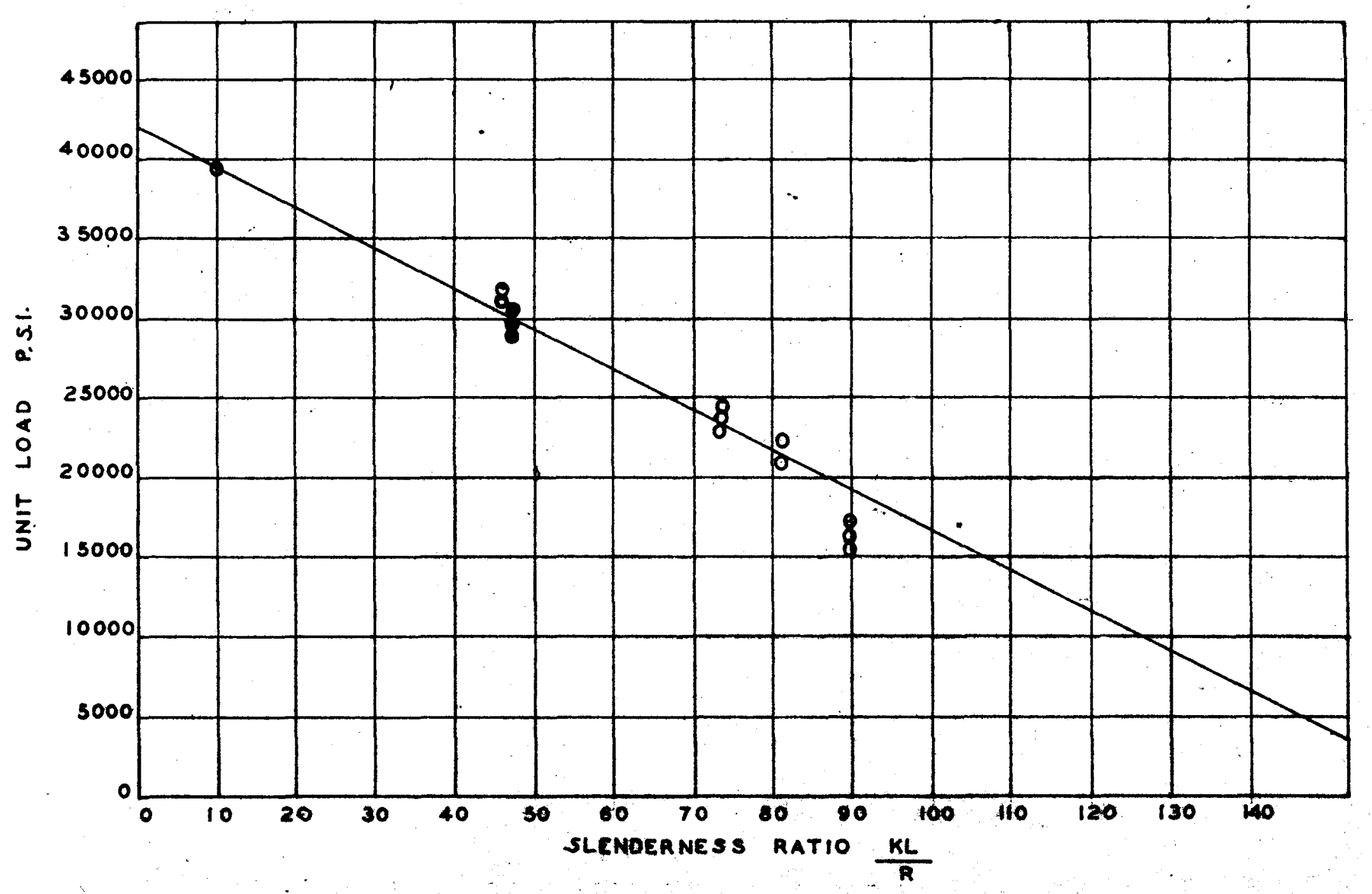

Figure 11. UnIt Iosd rs. Slenderness Ratlo for R361-T6 Tubing Columns, $0.238^{n} \times 1.625^{n}: \mathrm{x}=1,0.7,0.5$.

o Plinned Inds, O One Rlxod one Plnned Hnd, - Plxed Bnds. 


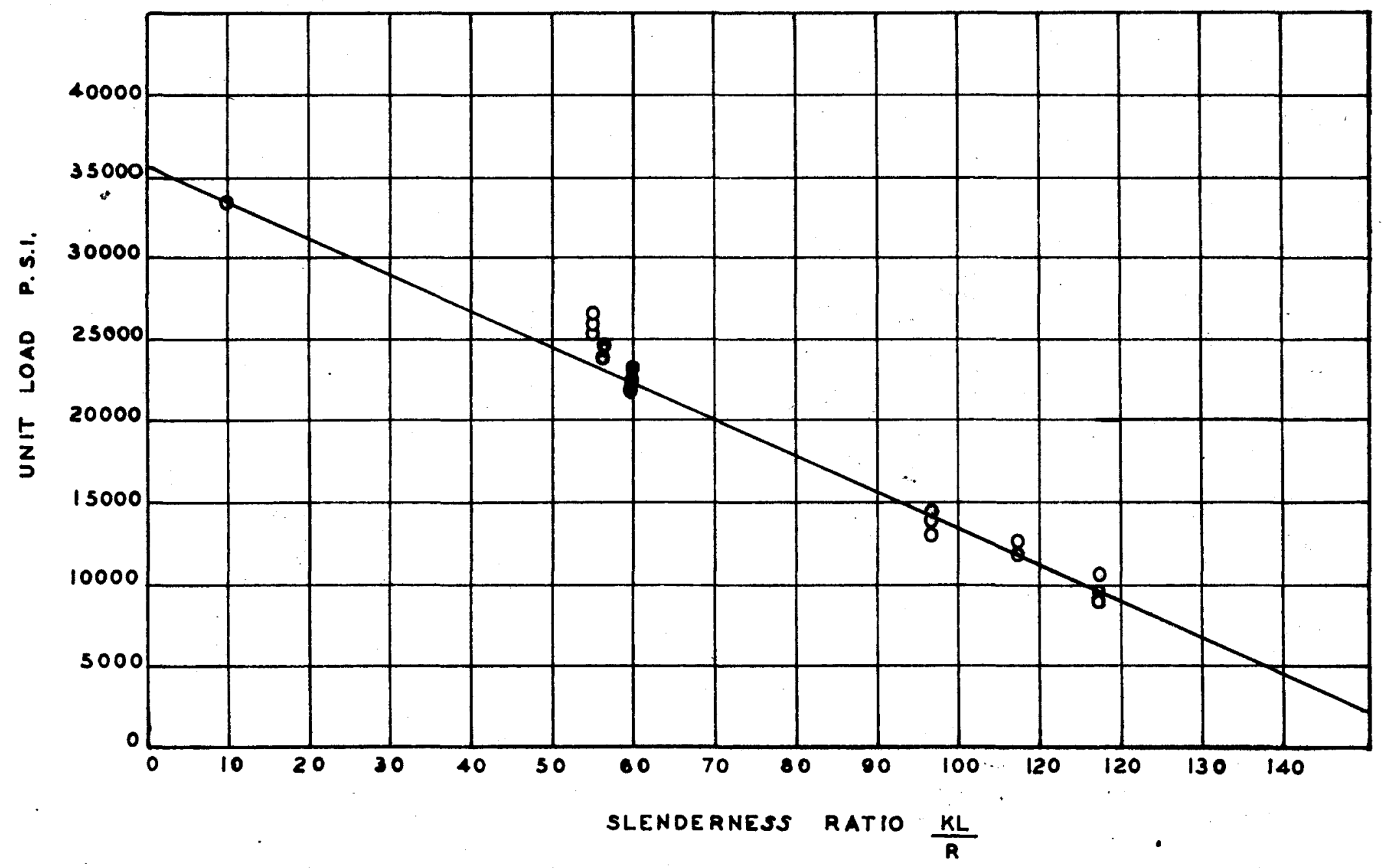

Figure 12. Unit Load rs. Slenderness Ratio for 635-T Tubing Columns, $0.3125^{\prime \prime} \times 1.875^{\prime \prime}$.

- Plnned End, 0 One Pinned \& One Fixed Ind, - Fixed Ends. 


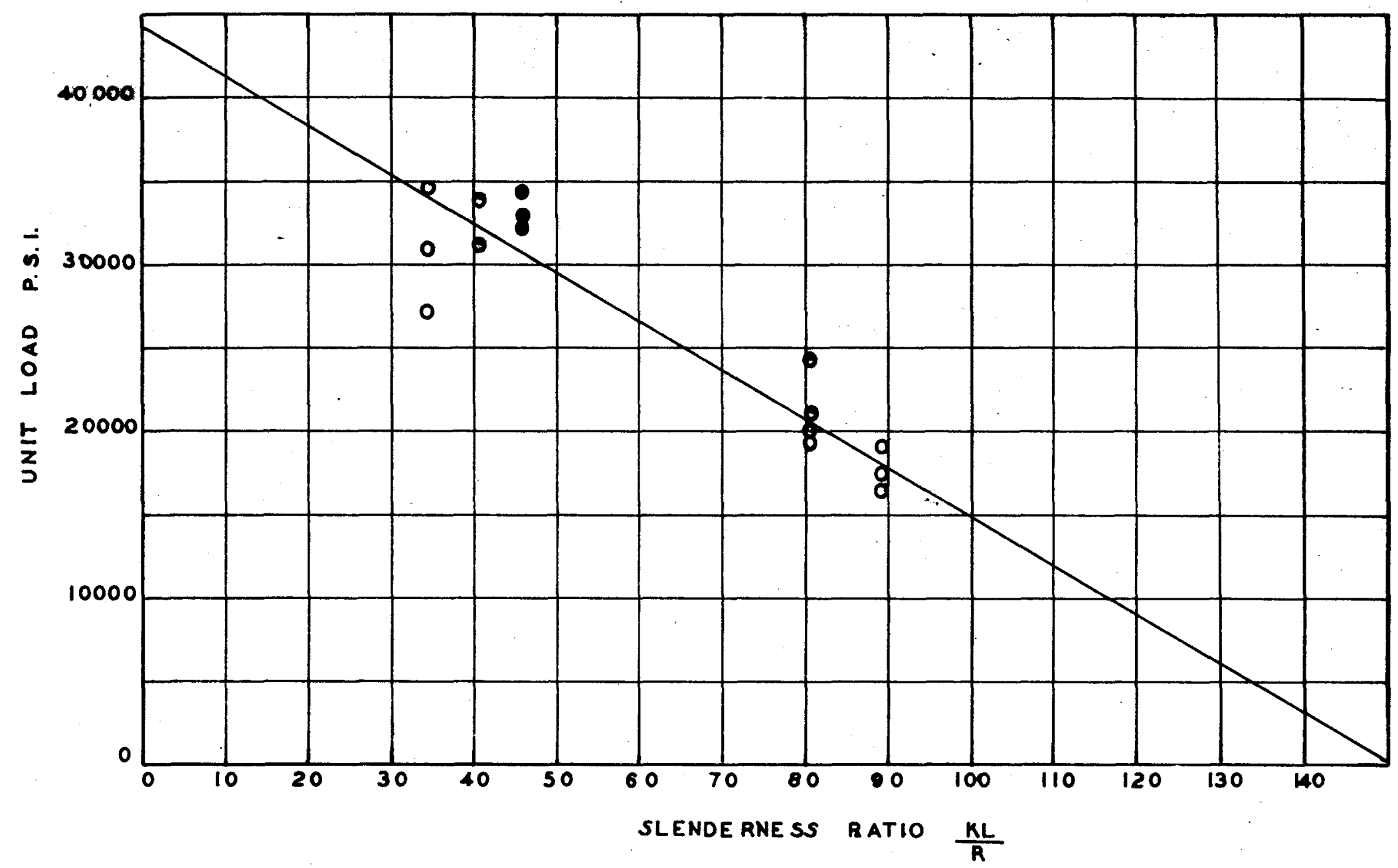
Fleare 13. Unit Load ra. Slendermose Ratto for $6361-T$ Channel Colunas,
$6^{*} \times 0.437 ; \mathrm{X}=1,0.7,0.5$

o Plnnod Inds, O Ono PLnned \& One Flred Bnd, - Fixed Inds. 


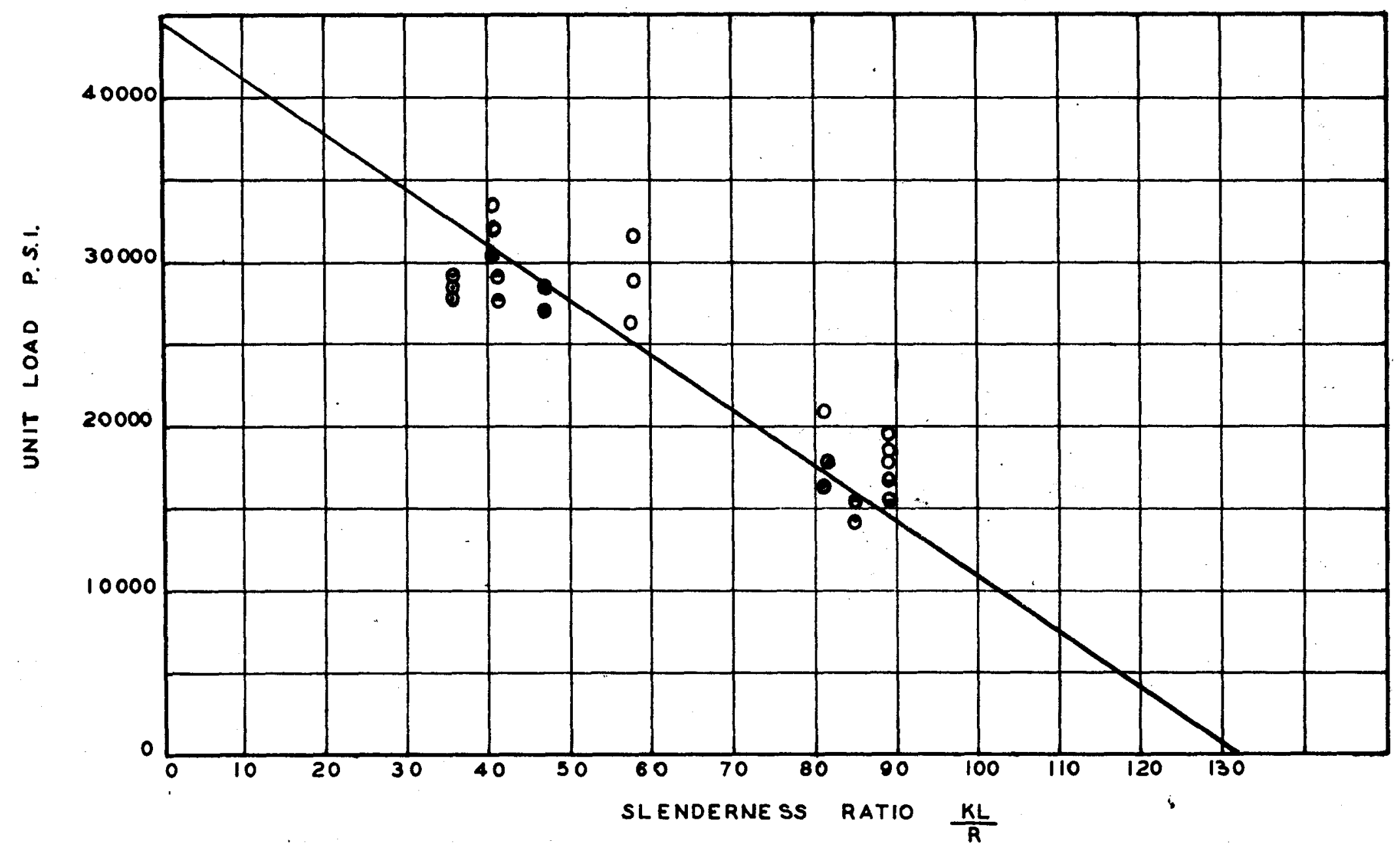

F1gure 14. Unit Load V8. Slenderness Rat10 for R361-T Anglo Columns $K=1,0.7,0.5$

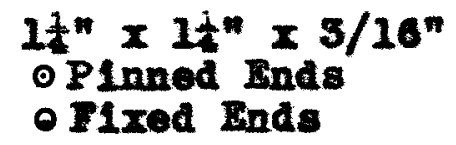

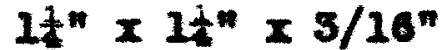$$
\text { - PInned Rnds }
$$$$
\text { O Fixed Bnds }
$$ 
CONCLUSIONS

On the basis of curves as plotted, the equations in Table XV are suggested as being as nearly correct as is warranted by the small number of columns tested. It is quite likely thet with larger number of test columns greater accuracy could be ob tained.

No equation 1 s given for 35 - 0 tubing because the spread of test results does not warrent ono. A single equation is given for material of the same general shape, for example two sizes of tubling. But equations of different value are given for the same material where the shape is different, for example the angles and channels. This treatment was employed not only bockuse it agreed wh test da but beouse it is generally accepted that the shaping does influence the slope of the equetion by effecting the actual physical properties of the metal.

TABLE XV

COLUMN FORMULAS

MA TERIAL

FORMULA

$33-\mathrm{H14}$

$P / A=27,000-155 \mathrm{~K}(\mathrm{~L} / \mathrm{r})$

R361-0

$P / A=8,000-34 K(L / r)$

B361-T4

$P / A=27,750-167.5 \mathrm{~K}(\mathrm{~L} / \mathrm{r})$

R361-T6

$P / A=42,000-253 \mathrm{~K}(L / \mathrm{r})$

$63 \mathrm{~S}-\mathrm{T}$

$P / A=35,500-220 \mathrm{~K}(\mathrm{~L} / \mathrm{r})$

R361-T

$P / A=44,000-290 \mathrm{~K}(\mathrm{~L} / \mathrm{r})$

B361-T

$P / A=44,000-340 \mathrm{~K}(\mathrm{~L} / \mathrm{r})$ 
BURS TING AND COLLAPSINO PRESSURES

OF ALUMINUM TUBES 
THEORETCAL

It ba been observed previously that the cost of aluminum in recent jesrs bas declined because of increased output and advances in the technological field. This decrease in cost bas brought aluminum into competition with many of the so-called standard materials. The bursting and collapsing strength bas become important in fluid transportation, since aluminum has high resistance to corrosion and can be extruded a smooth bore tube. It also finds uses in 011 well driling and pumping. It is here that the collapsing data are very essential. The burstIng data are essential because liluds are usually transported under pressure, to increase the rate of flow and reduce costs.

Bursting Theory

The bursting of thlck cylinders is shown by Lame's Solution to follow the equation:

$$
\max s=\frac{r_{2}^{2}-r_{1}^{2}}{r_{2}^{2}-r_{1}^{2}}
$$

Where:

$S=$ Circumferential Un1t stress, 1bs/sq. In.

$P=$ Internal fluld pressure, $1 \mathrm{bs} / \mathrm{sq} .1 \mathrm{n}$.

$r_{1}$ - Internal radus of cylinder, inches

$r_{2}=$ Extemal radius of cylinder, inches.

Lame's solution makes two assumptions: (1) that the thick cylinder 13 composed of a series of thin cylinders each of which has an equal distribution of stresses througbout 1 ts thickness and 
(2) that the strains of all the longltudinal fibers are oqual; that 1s, the tube maintains its geometric shape. This last asumption does not hold at the closed ends of a cylinder where a distinct change in geometric ubape can take place under the inPluence of internal pressure.

The well known Barlow formula for bursting pressures may be applied to thick cylinders. In this formula it is assumed that the wall thicknoss and the diameter do not change during the period the specimen is undergoing stress, an asumption which is not exact. Barlow's formula 1s:

$$
P=\frac{s t}{r_{2}}
$$

Where:

$$
\begin{aligned}
& P=\text { internal pressure, 1bs./sq. In. } \\
& t=\text { wall thlckness, Inches } \\
& r_{2}=\text { external radius, Inches } \\
& s=\text { unit stress, Inside lber, Ibs/sq. In. }
\end{aligned}
$$

Collapsing Theory

Tubes collapse because of the application of load which will exceed the elastic limlt of the material, or they may fall before the elastic limlt is reached due to insufficlent flexural rigidity of cross-sectional circular ring. Fallure occurring for the second reason 19 often far below the elastic 1imit. This flexural rigidity is insufficient because of two physical deformations, (1) wall becoming thinner in particular section, (2) slight elliptical shape instead of circular. The elliptical deformation is the more important of the two. For 
the case of a circular ring collapsing bocause of elliptical formation the following equation has been derived by Timoshenko:

$$
q_{c r}=\frac{3 E I}{r^{3}}
$$

Wheres

$$
\begin{aligned}
& q_{c r}=\text { critical pressure, } 1 b s / \text { und length } \\
& E=\text { modulus of elasticity } \\
& I=\text { moment of inertia } \\
& r=\text { radius of gyration }
\end{aligned}
$$

The theory of collapsing of tubes follows from this equation, since tube may be considered as sub-divided into a number of rings. If from tube cross section of unit length 1 s cut 1 ts moment of inertia is:

$$
I=\frac{1 \cdot h^{3}}{12}
$$

and $E$ becomes $\frac{E}{1-\mu 2}$, where $\mu$ is Poisson's Ratio. The above equation now becomes: $\mathrm{PCr}=\frac{\mathrm{Eh}^{3}}{4(1-\mu 2) \mathrm{R}^{3}}$. Th1s equation holds Where: $h=$ wall thlckness, Inches, $P_{\text {cr }}=$ Crltical, pal, $R=$ radius of conter line of cylinder, inches, for tubes a long as the proportional limlt has not been reached. In the work herein reported the apecimens did not approach the proportional limft in test results, indicating that the specimens falled because of elliptical deformation. A check was made of wall thicknesses to determine whether or not this factor could have contributed to their fallure. No deviations of sufficient proportions were found.

Beyond the elastic limlt, or after the proportional limit has been reached, the above ocuation gives values which 
are too hlgh. The following equation may be used to represent the oritical results:

$$
P_{\text {or }}=\frac{h}{R} \frac{\gamma \text { mp }}{1-4 \frac{\gamma p}{E} \frac{R^{2}}{h^{2}}}
$$

Where:

$\gamma_{y p}=$ yield point in ompression

Th1s disoussion sas not included the effect which an end closure on a tube would have. It is known that the stresses In a short speoimen are altered by the support afforded by the end closures. It $1 \mathrm{~s}$ also known that a short specinen w11l collapse with a series of waves along the olfoumference. The length usually taken as being a long speoimen for these oonditions has an $L / Y=20$. The lengths used in these tests gave $L / x$ values from 21 to 12. However, none of the fallures corresponded to the short speoimen type. All of them falled by a collapse from one side and there was no Indioation of a series of waves along the olrcumferenoe. Therefore, it is belleved that no oorrection for this short specimen factor is necessary. Howerer, the end closures would have a tendenoy to lnorease the oritioal pressures. 


\section{EXPEIIMENTAL}

The specimens for bursting were cut $31 x$ feet long to minimize the influence of the end closures on the streng th of the tube. The end closures were made in three parts. A tapered plug was driven into the end of the specimen to enlarge 1t. A block with tapered center bole was fltted around the end of the specimen with the tapered plug in position. In to the end of the block and facing the tapered plug a screw was placod to bear against the plug, thereby providing a tight fit. This arrangement was sufflcient to prevent the plug from sliding from the tube under pressure, and the tapered grip wes adequate to provent the block from sllding off the specimen, and to prevent leakage. A positive displacement, radial piston pump delivering 3 gal. of hydraullc fluld per minute was used to develop pressure. The fluid was passed into the tube through the end closures. The bursting faliure was observed on pressure gage.

Each specimen for collapsing tests was cut $30^{\prime \prime}$ long and the ends mechined square in order that they, would fit tightly in to aluminum blocks used a end closures. These end closures were blocks into mich were machlned grooves for the various size specimens to fit. The two end closures were joined by tie rod pessing axially through the specimen. The specimen after beling thus closed was placed inside steel tank, of welded construction, with top which was bolted onto heavy flange. The same pump used in the bursting tests was used to develop pressure within the tonk and around the specimen. A pressure gage Indicated when the specimen had collapsed. 
CONCLUSIONS

Bursting test results were consistent, with duplicate da ta on two of the $4 \mathrm{in}$. dlameter specimens and on two of the 5 in. diameter specimens. Three three inch specimens gave results within 10\%. The calculations shown in Table XVI give satisfactory results w1 th agreement, between the Barlow and Lame formulae. Accordingly, it is belleved the these results indicate that the Barlow and Lame are rellable formulae for use in design of aluminum fluid flow system, for intemal pressure.

The experimental collapsing values of the unit pressure upon fallure of the 3 inch tube were Identical for two tosts and the unit prossure fallure of the 5 inch tube were the seme for two tests. Two of the three tests on the 4 Inch tube gave the same unit pressure at fallure and the third value was very close to these two. It was difficult to locate any great amount of reforence material on collapsing tests. Tlmoshenko's formula for critical unit pressure probably is satisfactory reference. The experimentel unit pressure at fallure were determined and these values were compared with the critlcal unit pressure as computed by THmoshenko's formula. In the case of the $4^{\prime \prime}$ tubes the experimental value was approximately $10 \%$ greater than the theoretical value and in the case of the 3 and 5 inch tubes the experimental values were approximately 50\% greater than the tbeoretical value. The data are shown in Table XVII. (There is no explanation of the wide range of test results.) 
TABLE XVI - BURSTING TEST DATA AND KELULTS

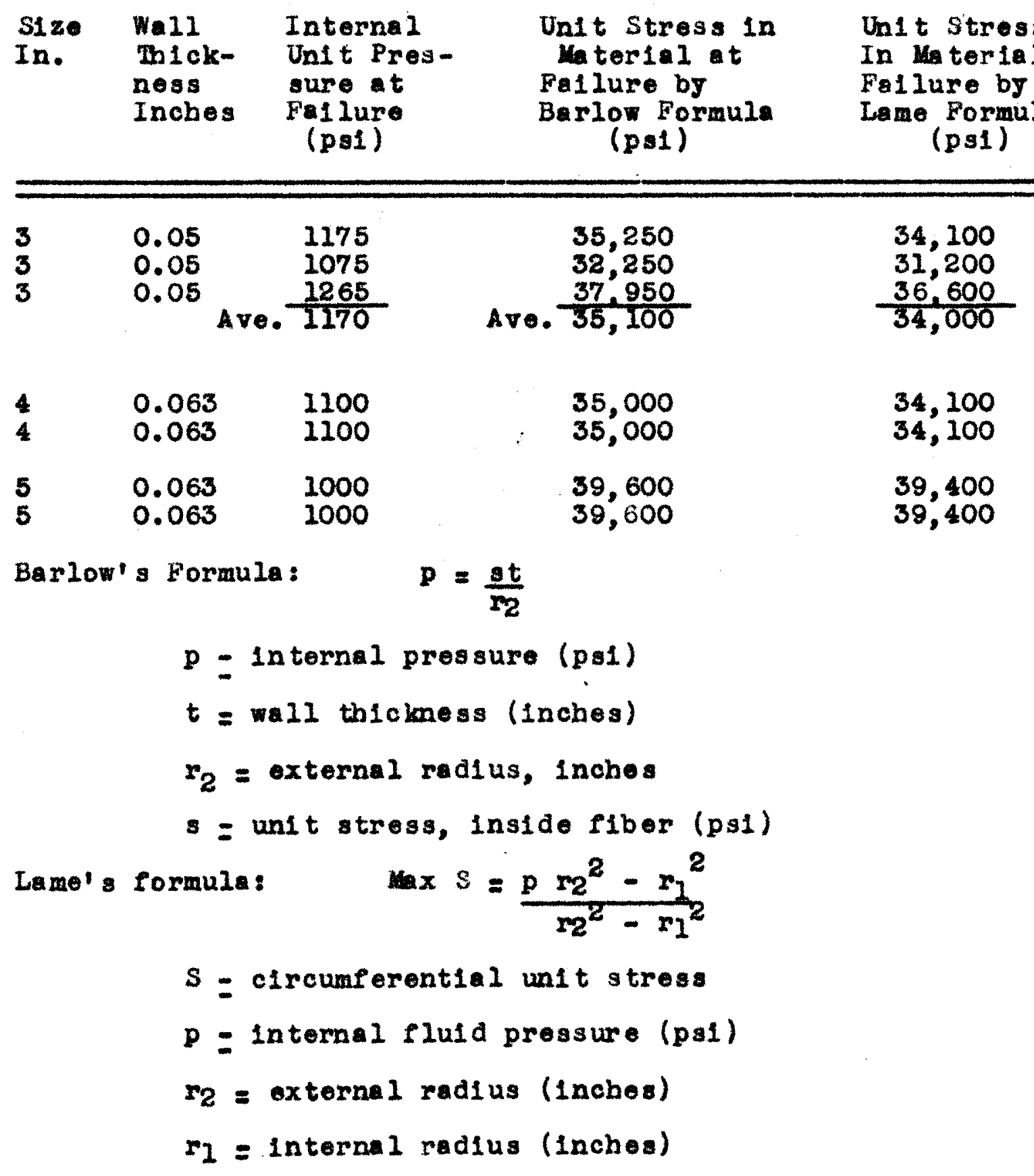


TABLE XVII - COLLAP ING TEST DATA AND RESULTS

\begin{tabular}{|c|c|c|c|c|}
\hline $\begin{array}{l}\text { S1zo } \\
\text { In. }\end{array}$ & $\begin{array}{l}\text { Wall } \\
\text { Thlckness } \\
\text { (Inches) }\end{array}$ & $\begin{array}{c}\text { Unit Prewsure } \\
\text { at Fallure } \\
\text { (psi) }\end{array}$ & $L / R$ & $\begin{array}{l}\text { Computed } P \text { cr } \\
\text { Prom TImoshenko's } \\
\text { Formula (psi) }\end{array}$ \\
\hline $\begin{array}{l}3 \\
3\end{array}$ & $\begin{array}{l}0.05 \\
0.05\end{array}$ & $\begin{array}{l}175 \\
175\end{array}$ & $\begin{array}{l}21.3 \\
21.3\end{array}$ & $\begin{array}{l}111 \\
111\end{array}$ \\
\hline $\begin{array}{l}4 \\
4 \\
4\end{array}$ & $\begin{array}{l}0.125 \\
0.125 \\
0.125\end{array}$ & $\begin{array}{l}800 \\
825 \\
825\end{array}$ & $\begin{array}{l}16 \\
16 \\
16\end{array}$ & $\begin{array}{l}725 \\
725 \\
725\end{array}$ \\
\hline $\begin{array}{l}5 \\
5\end{array}$ & $\begin{array}{l}0.08 \\
0.08\end{array}$ & $\begin{array}{l}150 \\
150\end{array}$ & $\begin{array}{l}12 \\
12\end{array}$ & $\begin{array}{r}98 \\
98\end{array}$ \\
\hline
\end{tabular}

Timoshenko's Formula, eg. 187, p. 219

Strength of terials, Part II

$P_{\text {cr }}=\frac{\mathrm{En}^{3}}{\operatorname{T(1-\mu 2)} \mathrm{R}^{8}}$

$P_{\text {Cr }}=$ critical unit pressure, psi

$\mathrm{E} \quad=$ modulus of elesticity $=10,600,000 \mathrm{ps}$

$\mu=$ Polsson's ratio $=0.33$

b $=$ wall thickness, inches

$R$ = radius of center line of cylinder, inches 
FLUID FLON CHARACTERISTICS OF ALUMINUM ALLOT PIPE 
THEO RE TI CAL

Power costs have always added considerably to the cost of the process of transporting fluids. Considerable work has been done in attempting to reduce this cost through a study of the factors involved. The friction between the moving fluid and the channel wall has been the power consumption factor which has glven the trouble. For the older or commonly used materials this problem has been solved in terms of a friction factor. The use of aluminum in the fleld of fluid transportation brings with it the need for determination of this friction factor for aluminum tubing.

The flow of eluids through tubing or plpes takes place In two different ways dependent upon the velocity of fluid the properties of the fluid and the dimensions of the pipe. At low velocities the flow occurs in a smooth even pattern, that $1 \mathrm{~s}$, it occurs in layers as demonstrated by Reynolds.* There is Iittle mixing of the 11quid in the channel. The velocity approaches zero t the wall surface and increases in approximately a parabolic manner a the center of the channel is approached. This type of flow is seldom encountered in engineering prectice and the project is not concerned with this flow.

The second type of flow is that at relatively hlgh velocities where the flow is turbulent and somembet complete mixing of the fluid take place. However, there is still a layer at the wall surface which approaches zero veloclty. The speed at

* Osborne Reynolds, 19th Century Phys1c1at. 
which the velocity increases as the conter of the channel is approched is much greater, than in laminar flow.

Reynold derlsed dimensionless factor, which has come to be known a Regnolds Number, to distingulsh betweon the two types of flow. It may be defined,

$$
\text { Re }=\frac{D V \rho}{\mu}=\frac{D Q}{\mu}
$$

Where:

$$
\begin{aligned}
D= & \text { diameter of pipe, } f t . \\
v= & \text { velocity of fluid, ft/sec. } \\
a= & \text { mase velocity, ib./(sq.ft. of pipe cross-section) } \\
& (\text { sec.) } \\
\rho= & \text { density, } 1 \mathrm{~b} . / \mathrm{ft}^{3} . \\
\mu= & \text { viscosity of fluid, } 1 \mathrm{~b} . / \mathrm{sec} . \mathrm{ft} .
\end{aligned}
$$

When the Reynolds Number is less than 2000 the flow of any fluid in any channel is of the slow or viscous type. In the range of 2000 to 2500 the flow may be elther type and very I1ttle is known about this region. Above 2500 the flow is always turbulent and is the range usually encountered in engineering work.

A term known as the Fanning Priction factor may be plotted versus the Reynolds Number. It is used to determine the friction between the fluid and the channel wall, and may be evaluated from loss of pressure in the channel, the dimensions of the channel, the velocity of flow and the properties of the fluid. In themetical form the relationship becomes:

$$
P=\frac{F D}{\left(V^{2} / 2 g\right) 4 L}
$$


Where:

$$
\begin{aligned}
& F=\text { eriction head, ft. of the flowing fluld } \\
& I=\text { ranning friotion factor } \\
& I=\text { length of plpe, ft. } \\
& D=\text { diameter of plpe, ft. } \\
& V=\text { velocity of fluld, } \mathrm{ft} / \mathrm{sec} . \\
& B=\text { goceleration of gravity, } 32.2 \mathrm{ft} / \mathrm{sec}^{2} .
\end{aligned}
$$

EXPERTMENTAL

The hydraulic test stand of the University of Loulsville Civil Engineering Department was used for this phase of the work. The two sections of aluminum pipe were used, 2 and 4 Inch dlameters, eaoh $20 \mathrm{ft}$. long. Manometer taps were placed five feet from the up stream end and one foot from the down stream end. The tubing was then plaoed in the stand and connected. The stand was equipped with a centrifugal pump to deliver a steady flow of water. The tests were started at the maximum pumping rate and decreased in subsequent runs. Weight rates and absolute pressures were recorded simultaneously. The flow of water was reduced by an outlet valve after each series of runs, to obtain pressure value at several rlow rates. This procedure was continued to a flow rate at whlch the pump could not maintain Its prine. The same technique was employed for the 4-inch diameter plpe. 
CONCLUSIONS

The data shown in Table XVIII and Table XIX were calculated using the formulas cited above for Reynolds number and friction factor:

$$
\begin{aligned}
R_{e} & =\frac{D G}{\mu} \\
r & =\frac{D}{4 L} \cdot \frac{F}{\nabla 2 / 2 g}
\end{aligned}
$$

Then usling corresponding Reynolds numbers and friction factors these data were plotted on a reproduction of a portion of the Reynolds number-friction factor plot taken from Perry, Chemical Englneers Handbook, Second Edition, page 811 (10). On this plot the accepted ourves for commercial plpes and smooth tubes are shown.

The data are very good, only three points falling outside the range between commercial plpes and smooth tubes. In general, the data for the 2-1nch pipe tend to approach the curve for smooth tubes, whereas the data for the 4-inch pipe tend to approach the curve for commerclal pipe. However, it is observed that substantially all the data fall within the range between oomerclal pipe and smooth tubes indicating that the 4-inch pipe was slightly smoother than commerclal pipe and the 2-Inch plpe slightly rougher than "gmooth" tubing. 
TABLE XVIII - FLOW DATA FOR TWO-INCH PIPE

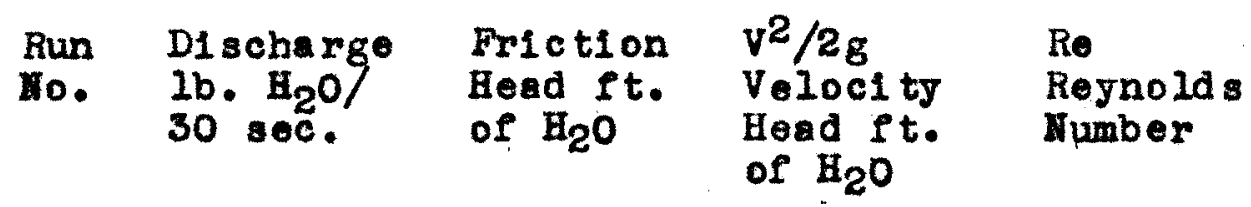

$F$

Fanning

Friction

Factor

\begin{tabular}{llllll}
\hline 1 & 627.9 & 6.41 & 4.52 & $2.502 \times 10^{5}$ & 0.00401 \\
2 & 630.4 & 6.41 & 4.56 & 2.513 & 0.00398 \\
3 & 632.1 & 6.41 & 4.58 & 2.519 & 0.00395 \\
4 & 600.8 & 5.78 & 4.14 & 2.394 & 0.00395 \\
5 & 596.6 & 5.78 & 4.08 & 2.378 & 0.00400 \\
6 & 591.9 & 5.78 & 4.02 & 2.359 & 0.00407 \\
7 & 573.0 & 5.25 & 4.76 & 2.284 & 0.00394 \\
8 & 574.3 & 5.25 & 3.93 & 2.289 & 0.00377 \\
9 & 574.3 & 5.25 & 3.93 & 2.288 & 0.00377 \\
10 & 545.6 & 4.73 & 3.41 & 2.174 & 0.00393 \\
& & & & & \\
11 & 546.0 & 4.73 & 3.42 & 2.176 & 0.00391 \\
12 & 546.0 & 4.73 & 3.43 & 2.179 & 0.00390 \\
13 & 512.6 & 4.20 & 3.01 & 2.043 & 0.00394 \\
14 & 512.1 & 4.20 & 3.01 & 2.041 & 0.00395 \\
15 & 510.9 & 4.20 & 2.99 & 2.036 & 0.00397 \\
16 & 467.6 & 3.68 & 2.51 & $1.863 \times 10^{5}$ & 0.00414 \\
17 & 475.3 & 3.68 & 2.59 & 1.894 & 0.00401 \\
18 & 473.6 & 3.68 & 2.57 & 1.887 & 0.00404 \\
19 & 432.9 & 3.15 & 2.15 & 1.725 & 0.00443 \\
20 & 434.6 & 3.15 & 2.17 & 1.732 & 0.00440 \\
& & & & & \\
21 & 433.7 & 3.15 & 2.16 & 1.768 & 0.00413 \\
22 & 393.9 & 2.63 & 1.78 & 1.530 & 0.00417 \\
23 & 390.0 & 2.63 & 1.74 & 1.554 & 0.00426 \\
24 & 390.4 & 2.63 & 1.75 & 1.556 & 0.00425 \\
25 & 345.4 & 2.10 & 1.37 & 1.377 & 0.00434 \\
26 & 342.4 & 2.10 & 1.36 & 1.364 & 0.00437 \\
27 & 340.3 & 2.10 & 1.33 & 1.356 & 0.00447 \\
28 & 287.1 & 1.58 & 0.95 & 1.144 & 0.00471 \\
29 & 227.7 & 1.58 & 0.59 & 0.901 & 0.00748 \\
30 & 281.1 & 1.58 & 0.91 & 1.120 & 0.00491 \\
& & & & & \\
\hline
\end{tabular}

Length of Test Section: $14.0 \mathrm{ft}$.

Measured Diameter of P1pe: 1.90 in., I. D.

Water Temperature: $20^{\circ} \mathrm{C}$. 
TABLE XIX - FLOW DA TA FOR A FOUR-INCH PIPE

\begin{tabular}{|c|c|c|c|c|c|}
\hline $\begin{array}{l}\text { Run } \\
\text { No. }\end{array}$ & $\begin{array}{l}\text { Di scharge } \\
10 . \mathrm{H}_{2} \mathrm{O} / \\
30 \text { sec. }\end{array}$ & $\begin{array}{l}\text { Friction } \\
\text { Head ft. } \\
\text { of } \mathrm{H}_{2} \mathrm{O}\end{array}$ & $\begin{array}{l}\mathrm{v}^{2} / 2 \mathrm{~g} \\
\text { Velocity } \\
\text { Head ft. } \\
\text { of } \mathrm{H}_{2} \mathrm{O}\end{array}$ & $\begin{array}{l}\text { Ro } \\
\text { Re ynolds } \\
\text { Number }\end{array}$ & $\begin{array}{l}\text { F } \\
\text { Fanning } \\
\text { Friction } \\
\text { Factor }\end{array}$ \\
\hline $\begin{array}{l}1 \\
2 \\
3 \\
4 \\
5\end{array}$ & $\begin{array}{l}713.0 \\
708.5 \\
717.5 \\
707.0 \\
695.0\end{array}$ & $\begin{array}{l}0.256 \\
0.224 \\
0.287 \\
0.292 \\
0.268\end{array}$ & $\begin{array}{l}0.337 \\
0.333 \\
0.342 \\
0.332 \\
0.320\end{array}$ & $\begin{array}{l}1.394 \times 10^{5} \\
1.385 \\
1.403 \\
1.382 \\
1.359\end{array}$ & $\begin{array}{l}0.00438 \\
0.00387 \\
0.00485 \\
0.00507 \\
0.00482\end{array}$ \\
\hline $\begin{array}{l}6 \\
7 \\
8 \\
9 \\
10\end{array}$ & $\begin{array}{l}687.5 \\
685.0 \\
687.0 \\
686.0 \\
614.0\end{array}$ & $\begin{array}{l}0.260 \\
0.253 \\
0.268 \\
0.253 \\
0.224\end{array}$ & $\begin{array}{l}0.313 \\
0.311 \\
: 0.313 \\
0.312 \\
0.250\end{array}$ & $\begin{array}{l}1.344 \\
1.339 \\
1.343 \\
1.341 \\
1.200\end{array}$ & $\begin{array}{l}0.00493 \\
0.00469 \\
0.00493 \\
0.00467 \\
0.00516\end{array}$ \\
\hline $\begin{array}{l}11 \\
12 \\
13 \\
14 \\
15\end{array}$ & $\begin{array}{l}615.0 \\
567.5 \\
570.0 \\
529.0 \\
523.0\end{array}$ & $\begin{array}{l}0.224 \\
0.189 \\
0.189 \\
0.116 \\
0.166\end{array}$ & $\begin{array}{l}0.251 \\
0.214 \\
0.215 \\
0.186 \\
0.182\end{array}$ & $\begin{array}{l}1.202 \\
1.109 \\
1.114 \\
1.034 \\
1.022\end{array}$ & $\begin{array}{l}0.00514 \\
0.00509 \\
0.00506 \\
0.00514 \\
0.00525\end{array}$ \\
\hline $\begin{array}{l}16 \\
17\end{array}$ & $\begin{array}{l}489.0 \\
582.0\end{array}$ & $\begin{array}{l}0.144 \\
0.146\end{array}$ & $\begin{array}{l}0.158 \\
0.244\end{array}$ & $\begin{array}{l}0.956 \\
1.138\end{array}$ & $\begin{array}{l}0.00525 \\
0.00345\end{array}$ \\
\hline
\end{tabular}

Length of Test Section: $14.0 \mathrm{ft}$.

Mes sured Diameter of P1pes 3.875 in, I. D.

Water Temperature: $20^{\circ} \mathrm{C}$. 


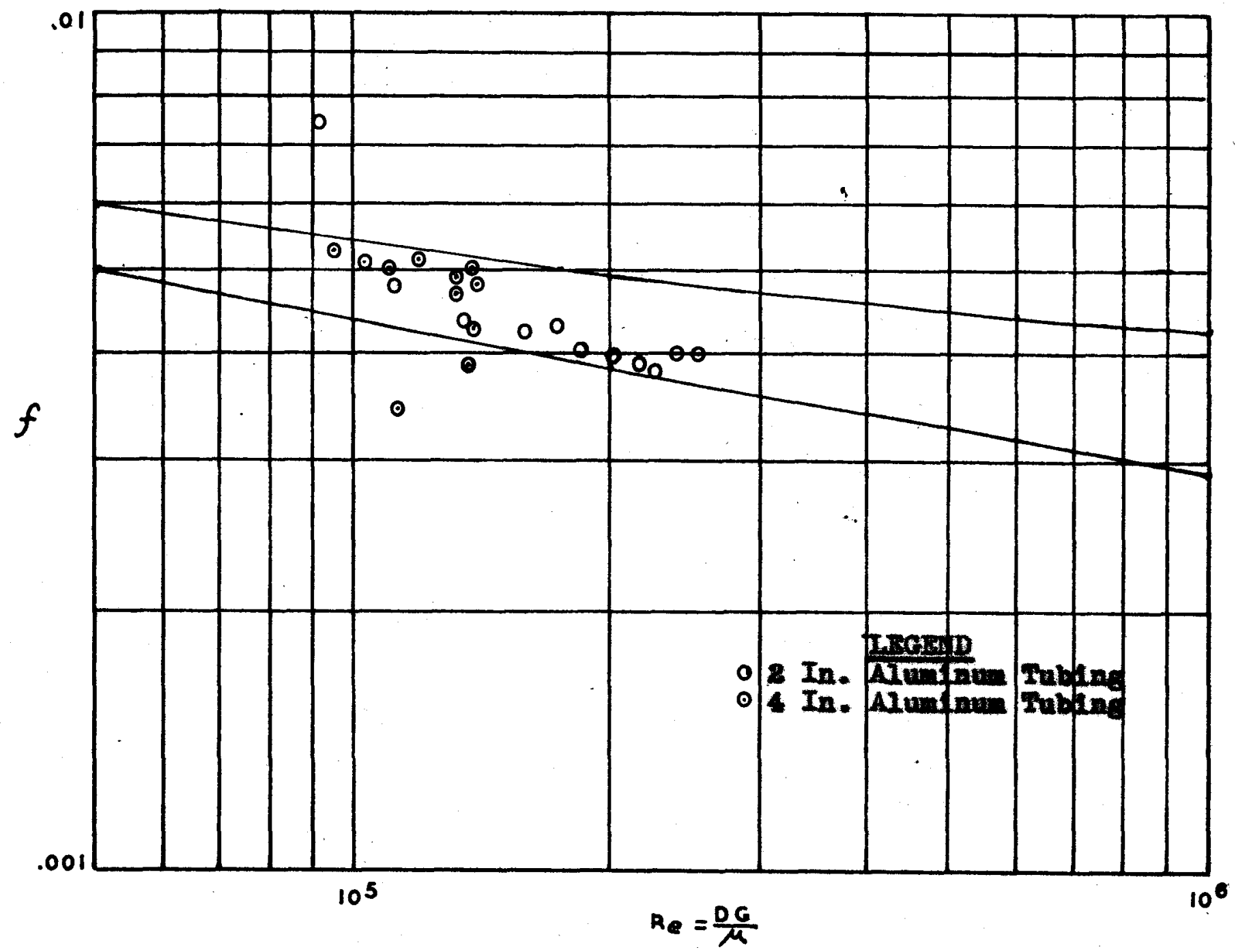

Igure 15. Fanning Friotlon Faotor ve. Regnola Henbor

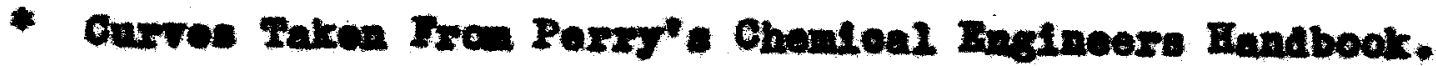




\section{BIBLIOGRAPHY}

(1) Langhaar, Henry L., J. Aeronaut. Se1., 10:7:218

(2) Marshall and Holt, Proc. Am. Soc. Civil Engrs., 64:1787-1807 (1938)

(3) Leary and Holt, Nat. Advisory Com. Aoronat., Tech. Note No. 1027, May 1946

(4) Holt and Leary, Nat. Advisory Com, Aeronaut., Toch. Note Mo. 1004, Jan. 1946

(5) Osgood, W. R., Proc. Am. Soc. C1vil Engrs.

v. 70, 1565-71 (1944)

v. 71 , No. $2,3,5,6,9$, (1945)

(6) Osgood, W. R. Hat. Advisory Comm. Aeronaut., Tech. Rept. Ho. 615

(7) Roed, Paul, 011 Gas J., 46:141 (1948)

(8) Jefferiea, Z, ot a l, Proc. Am. Soc. Civil Engrs., $102: 1267$ (1937)

(9) TImoshenko, S. P., Strength of teri als, Part II (1941) D. Van Nostrand Co., Hew York.

(10) Perry, John H., Cbemical Engineers' Hendbook, McGrew-HIII book Co., New York. 
APPENDIX 
RECORDED ELPERIMENTAL DATA

COLUMN TESTING

Speo. No.

Column Cross Section

Area - Square Inches

Load at Failure

Ibs.

I PS 1

I PS 2

0.19

650

I PS 3

600

525

I PI 1

0.18

400

I PI 2

450

I PSX 1

0.19

750

I PSX 2

750

I PI 1

0.19

325

I PL 2

300

I PI 3

300

3 PSX 1

3 PSX 2

0.241

4,600

3 PS 1

0.241

4,650

3 PS 2

3,050

3 PS 3

3,200

2,950

3 PI 1

0.24

2,500

3 PI 2

3 PI 3

2,550

2,600

3 PL 1

3 PL 2

3 PI 3

0.241

2,300

2,450

1,950

3 OI 1

3 OI 2

0.241

2,650

3 OI 3

2,400

2,600

3 FsX 1

0.241

3,850

3 TSX 2

3 FSX 3

4,050

4,500

4 PSX 1

0.562

10,450

4 PSX 2

0.562

5,975

4 PS 1

4 PS 2

6,350

4 PS 3

5,925

4 PI 1

4 PI 2

0.562

5,500

5,500

4 PI 3

5,575 
RECORDED TSPIRTMENAL DATA

COLUMN TESTING

(Continued)

Speo. No.

Column Cross Section

Area - Square Inches

Load at Fallure ps1

4 PI 1

0.562

4,950

5,000

4 PI 3

4,975

4 osx 1

0.562

10,700

$4 \cos x 2$

10,600

4 0.3X 3

10,800

$4 \mathrm{FSX} 1$

0.562

10,900

4 FSX 2

11,200

$4 \operatorname{FSX} 3$

10,750 :

5 PSX 1

0.80

4,000

5 PSX 2

3,200

5 PSX 3

3,850

6 PSX 1

6 PSX 2

2.195

5,700

5,850

6 PS 1

6 PS 2

1.195

2,750

2,625

6 PS 3

3,050

6 PI 1

6 PI 2

2.195

2,200

2,650

6 PI 3

1,550

6 PI 1

1.195

2,200

$6 \mathrm{PL} 2$

2,200

6 PL 3

2,100

8 PSX 1

1.102

25,100

8 PSX 2

23,800

8 PSX 3

24,300

6 PS 1

8 PS 2

1.102

11,900

8 PS 3

$10,68 \mathrm{~B}$

12,025

8 PI 1

1.102

9,825

8 PI 2

8 PI 3

20.350

$\Psi_{4} 4: 75$

$\begin{array}{lll}8 & \text { PL } & 1 \\ 8 & \text { PL } & 2 \\ 8 & \text { PL } & 3\end{array}$

1.102

8,250

7,950

8,625 
RECORDED EXPERTMENTAL DATA

$$
\begin{aligned}
& \text { CoLUMN Thsting } \\
& \text { (Continued) }
\end{aligned}
$$

$\begin{array}{lc}\text { Speo. No. Column Cross Section } & \text { Load at Failure } \\ \text { Area - Square Inches } & \text { ps1 }\end{array}$

$8 \operatorname{osx} 1$

8 OSX is

$80,3 \times 3$

8 OI 1

8 OI 2

8 OI 3

8 OL 1

8 OL 2

8 FSX 1

8 FSX 2

8 FSX 3

7 FS 1

7 FS 2

7 FS 3

9 PS 1

9 PS 2

9 PS 3

9 PI 1

9 PI $\frac{1}{2}$

9 PI 3

9 PI 1

9 PL 2

9 PL 3

$9 \operatorname{OSX} 1$

$9 \operatorname{osx} 2$

9 osx 3

9 PSX 1

9 ISX 2

9 FSX 3

9 FS 1

9 FS 2

9 IS 3

9 FI 1

9 FI 2

9 FI 3
1.102

20,500

20,200

20,800

1.102

8,375

8,850

9,400

1.102

7,500

7,400

1.102

19,100

19,400

18,700

0.189

2,000

1,850

2,500

1.205

29,725

28,850

27,500

1.205

25,550

25,850

26,975

1.205

20,650

20,075

19,000

1.205

38,000

38,200

37,900

1.205

37,200

36,150

35,000

1.205

16,700

16,300

16,300

1.205

12,600

12,450

12,900 
RECORDED EXP ERIMENTAL DATA

COLUMAN TESTING

(Continued)

Spec. No.

Column Cross Seotion

Area - Square Inches

Load at Fallure ps1

9 FI 1

9 FI 2

1.205

10,400

11 PSX 1

1.542

10,650

11 PSX 2

40,200

11. PS 1

11 PS 2

1.542

39,500

11 PS 3

20,600

22,450

21,700

II PI 1

II PI 2

1.542

19,425

19,675

11 PI 3

18,500

11 PI 1

$11 \mathrm{PL} 2$

1.542

14,100

16,350

11 PL 3

14,300

11 osX 1

1.542

37,800

11 osX 2

38,000

11 OSX 3

38,550

11 FSX 1

$11 \operatorname{PsX} \frac{1}{2}$

1.542

35,650

34,650

12 PS 1

12 PS 2

3.820

135,800

104,000

12 PI 1

3.820

80,000

12 PI 2

76,500

12 PI 3

73,000

$12 \mathrm{PL} 1$

3.820

63,000

$12 \mathrm{PI} 2$

66,500

12 PL 3

71,500

12 os 1

3.820

120,000

12 os 2

130,000

12 OI 1

12 OI 2

64,000

3.820

63,250

54,900 
FIC ORDED EXPERIMENTAL DATA

COLUMN TESTING

(Cont I nued)

Spoo. No.

Column Cross Seotion

Area - Square Inohes

Load at Faliure ps1

12 FS 1

12 FS 2

12 Fs 3

3.820

122,400

124,500

12 FI 1

12 FI 2

3.820

48,400

47,000

14 FS 1

14 FS 2

1.190

17,600

17,600

14 FS 3

17,700

14 FI 1

1.200

14, 700

15,750

14 FI 2

14 FI 3

14 FL 1

14 FL 2

$1.19 n$

12,600

12,000 


\section{RECORDED EXPERIMENTAL DATA}

\section{Fluid Flow 2-Inch Pipe}

Run No. In. of $\mathrm{Hg}$. Tare Wolght, Lbs. Total Weight, Lbs.

\begin{tabular}{llll}
\hline 1 & 6.1 & 264.0 & 996.5 \\
2 & 6.1 & 244.0 & 979.5 \\
3 & 6.1 & 253.5 & 991.0 \\
4 & 5.5 & 209.0 & 905.0 \\
5 & 5.5 & 253.0 & 943.0 \\
6 & 5.0 & 208.0 & 876.5 \\
7 & 5.0 & 254.0 & 924.0 \\
8 & 5.0 & 253.5 & 923.0 \\
9 & 4.5 & 201.5 & 838.0 \\
10 & 4.5 & 252.0 & 889.0 \\
11 & 4.5 & 245.0 & 883.0 \\
12 & 4.0 & 210.0 & 808.0 \\
13 & 4.0 & 252.5 & 850.0 \\
14 & 4.0 & 253.5 & 849.0 \\
15 & 3.5 & 204.0 & 774.0 \\
16 & 3.5 & 219.5 & 774.0 \\
17 & 3.5 & 231.0 & 783.5 \\
18 & 3.0 & 213.0 & 717.0 \\
19 & 3.0 & 241.0 & 748.0 \\
20 & 3.0 & 245.0 & 751.0 \\
21 & 2.5 & 244.0 & 703.5 \\
22 & 2.5 & 243.0 & 698.0 \\
23 & 2.5 & 261.5 & 717.0 \\
24 & 2.0 & 205.5 & 608.5 \\
25 & 2.0 & 236.0 & 635.5 \\
26 & 2.0 & 256.0 & 653.0 \\
27 & 1.5 & 230.0 & 565.0 \\
28 & 1.5 & 263.0 & 587.0 \\
29 & 1.5 & 251.0 & 579.0 \\
& & & \\
\hline & & & \\
\hline
\end{tabular}

Length of Test Section: $14.0 \mathrm{ft}$.

Mea sured Diameter of Pipe: 1.90 in.

Wa ter Temperature: $200 \mathrm{C}$.

TIme of Collection: 35 seconds. 


\section{RECORDED EXPERIUENTAL DATA}

Fluid How 4-Inch P1pe

Fun Ho. In. of CCl4 Tre Weight, Lbs. Total Weight, Lbs,

\begin{tabular}{rlll}
\hline 1 & 5.25 & 235.0 & 948 \\
2 & 4.60 & 252.0 & 943 \\
3 & 5.90 & 252.0 & 970 \\
4 & 6.00 & 230.0 & 937 \\
5 & 5.50 & 250.0 & 945 \\
6 & 5.50 & 254.0 & 941 \\
7 & 5.20 & 238.0 & 923 \\
8 & 5.50 & 216.0 & 903 \\
9 & 5.20 & 260.0 & 946 \\
10 & 4.60 & 251.0 & 865 \\
11 & 4.60 & 229.0 & 846 \\
12 & 3.90 & 210.0 & 777 \\
13 & 3.90 & 242.0 & 812 \\
14 & 3.40 & 247.0 & 776 \\
15 & 3.40 & 263.0 & 786 \\
16 & 3.00 & 238.0 & 727 \\
17 & 3.00 & 251.0 & 733 \\
& & & \\
\hline
\end{tabular}

Length of Test: $14.0 \mathrm{ft}$.

Hoasured Diameter of Pipe: 3.875 in.

Water Temperature: $20^{\circ} \mathrm{C}$.

Time of Collection: 30 seconds 
COLUMN TESTINO NOMENCLA TURE

MA TERIAL DESIGMATION

Dimensions

\begin{tabular}{|c|c|c|c|}
\hline Lab. No. & Shape & Alloy & thickness - Outside Diam. \\
\hline 1 & Tubing & $3 s-0$ & 0.065 inches $\times 1.00$ in. \\
\hline 2 & $n$ & $3 S-1 / 2 H$ & $0.065 \mathrm{in.} \times 1.00 \mathrm{in}$ \\
\hline 3 & $n$ & $3 S-\mathrm{H} 14$ & $0.061 \mathrm{in.} x 1.3125 \mathrm{in}$. \\
\hline 4 & $n$ & $3 \mathrm{~S}-\mathrm{H} 14$ & 0.125 in. $x 1.5625$ in. \\
\hline 5 & $"$ & PB 61-0 & 0.194 in. $\times 1.500$ in. \\
\hline 6 & $n$ & $R 361-0^{\circ}$ & 0.254 in. $\times 1.75 \mathrm{in}$ \\
\hline 7 & " & $\mathrm{R} 361-\mathrm{T4}$ & $0.064 \mathrm{in} . \times 1.00 \mathrm{in}$ \\
\hline 8 & $n$ & $R 361-T 4$ & $0.238 \mathrm{ln} . \times 1.718 \mathrm{in}$ \\
\hline 9 & $n$ & $\mathrm{R3} 61-\mathrm{T} 6$ & 0.238 in. $x 1.625$ in. \\
\hline 10 & $"$ & $63-F$ & 0.25 in. $x 3.50 \mathrm{in.}$ \\
\hline 11 & " & $\mathrm{R} 361-\mathrm{T}$ & 0.3125 in. $x 1.875$ in. \\
\hline 12 & Channel & R361-T & 0.437 in. $\times 6.0$ in. \\
\hline 13 & Angle & $\mathrm{R} 361-\mathrm{T}$ & $1 \frac{1}{4}$ in. $x$ 1. $1 n \times 3 / 16$ in. \\
\hline 14 & $n$ & $R 361-T$ & 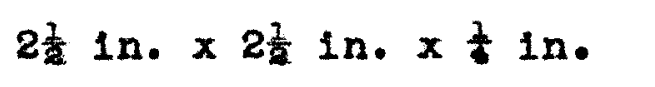 \\
\hline \multirow[t]{2}{*}{15} & " & $\mathrm{R3} 61-\mathrm{T}$ & 4 in. $x$ in. $\times 3 / 16$ in. \\
\hline & TYPE & END CONDITION & \\
\hline $\mathbf{P}$ & Both Ends & Pinned & \\
\hline $\mathbf{F}$ & $n$ & FIxed & \\
\hline 0 & One End $P 1$ & PInned and one $E$ & End Flxed \\
\hline
\end{tabular}


COLUMN TESTING NOMENCLATURE (Cont'd)

\section{COLUMN LENGTH}

L

I

$S$

SX
Long Column (Critical Length - 10\%)

Critical Length

Short Colum (Critical Length - 10\%)

Short Column (Critlcal Length - 50\%)

Typical Specimen designation:

4PLR: Sample 1 \& 3 S-H 14, 1/8" X 1-5/16"

Both onds pinned

Long Column

Second specimen tested under

deslgnated conditions. 
This researoh was made possible through a fellowship grant 1 rom

The Onfrersity of Loulsville Institute of Industrial Research as contracted research with

Reynolds Metals Company 
VI TA 
The author is the son of Mr. E. G. Baker and the late Mrs. Josephine Balfour Baker. He was born February 19, 1922 in Natchez, M1ss1ssippl, County of Adams, which was likewise the home and birth place of both parents.

The author attended the Publ10 Sohools of Natchez, Mississippi and graduated from Natchez High School in June of 1940. Subsequently he attended Mississipp1 State College, where he received a Bachelor of Sclence Degree in Chemical Engineering in september, 1943.

After graduation he socepted a position in the Mississippl Chemical Laboratorles, State College, Mississipp1, until June, 1944, when he entered the armed forces and was assigned to the 14th Chemlcal Service Battalion, Schoerield Barracks, T. H. After an honorable disoharge in Maroh, 1946 he resumed duties at M1ssissipp1 Chemical Laboratories unt11 September, 1946. From September, 1946 unt11 June, 1948 he was a sclence instructor in the Natchez Public Schools and in July, 1948 he entered the Unlversity of Loulsville on a fellowshlp grant from the Institute of Industrial Research. He recelved his Master of Chemical Engineering Degree from the University of Louisville in Deomber 1949, and continued on in the Institute of Industrial Research in the capacity of a Research Fellow. 